\title{
THE EFFECT OF NITROGEN FERTILIZATION ON THE MOVEMENT OF NUTRIENTS FROM A TROPICAL GRASS UNDER SOIL MOISTURE STRESS IN A HOT SAVANNA
}

\author{
By is \\ LUIS E! TERGAS
}

\begin{abstract}
A DISSERTATION PRESENTED TO THE GRADUATE COUNCIL OF THE UNIVERSITY OF FLORIDA

IN PARTIAL FULFILLMENT OF THE REQUIREMENTS FOR THE DEGREE OF DOCTOR OF PHILOSOPHY
\end{abstract}

UNIVERSITY OF FLORIDA 


\section{ACKNOWLEDGMENTS}

The author expresses his appreciation to Dr. William G. Blue for his guidance, assistance and interest during the course of this investigation.

Appreciation is extended to Dr. John E. Moore for his assistance during part of the investigation and constructive criticisms of the manuscript.

Appreciation is also extended to Dr. Fugh L. Popenoe, Dr. David S. Anthony, Dr. Charles O. Ruelke and Dr. Gordon B. Killinger for their constructive criticisms in the review of the manuscript and participation on the Graduate Supervisory Committee.

Thanks are extended to Mr. Edgar Rey-Gonzales and his staff at the Department of Animal Production, Costa Rican Ministry of Agriculture, for their valuable cooperation during the course of the investigation in Costa Rica. Thanks are also extended to Mr. Mauro Molina and his staff at the Enrique Jimenez Nuñez Agricultural Experiment Station, Taboga, Costa Rica, for their valuable help during the course of the field experiments.

The author wishes to extend his appreciation to the center for mroplcal Agriculture for granting the assistantship and financial assistance to the research project which made this study possible.

Thanks are expressed to Mrs. Martha Gomez for typing this dissertation. 
The author also expresses his appreciation to his wife for her understanding, patience and encouragement during his years as a graduate student, and help in the preparation of the manuscript. 


\section{TABLE OF CONTENTS}

Page

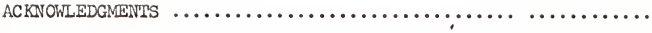

LIST OF TABLES $\ldots \ldots \ldots \ldots \ldots \ldots \ldots \ldots \ldots \ldots \ldots \ldots \ldots \ldots \ldots \ldots \ldots \ldots \ldots \ldots \ldots \ldots$

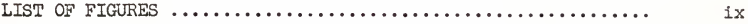

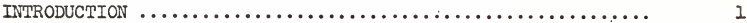

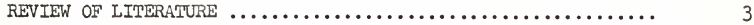

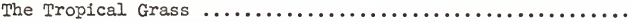

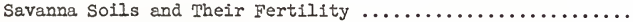

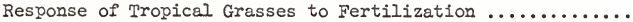

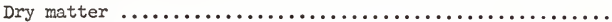

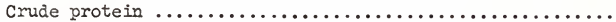

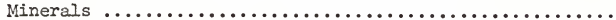

Fertilizer nitrogen recovery $\ldots \ldots \ldots \ldots \ldots \ldots \ldots \ldots \ldots \ldots$

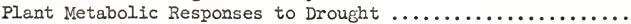

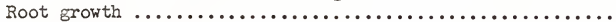

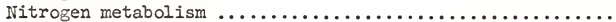

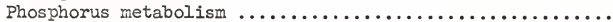

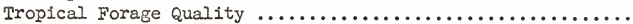

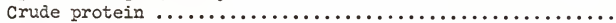

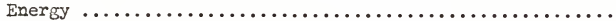

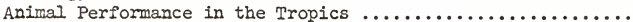

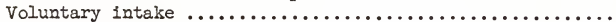

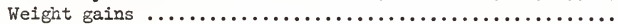

DESCRIPTION OF THE HOT SAVANNAS OF COSTA RICA ........... 25

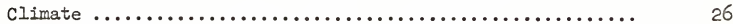

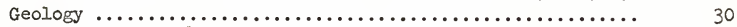

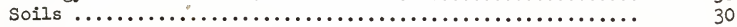

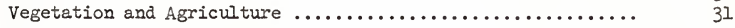

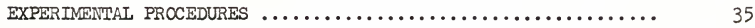

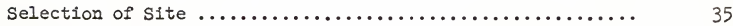

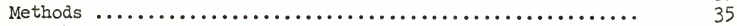

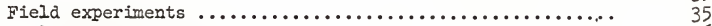

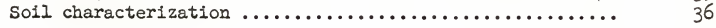




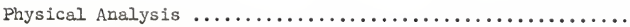

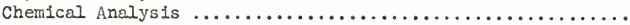

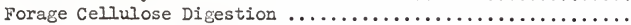

Statistical Analysis . . . . . . . . . . . . . . . . . . .

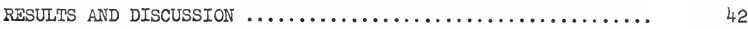

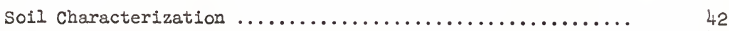

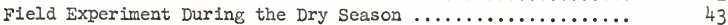

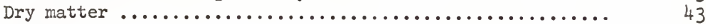

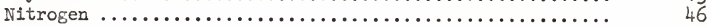

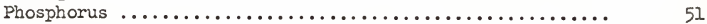

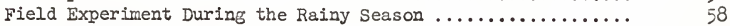

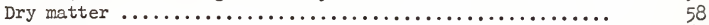

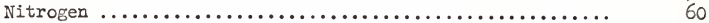

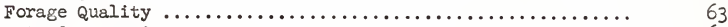

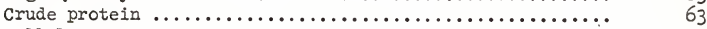

Cellulose concentrations and in vitro cellulose

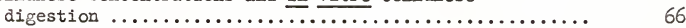

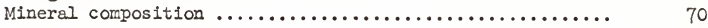

SUMMARY AND CONCLUSIONS $\ldots \ldots \ldots \ldots \ldots \ldots \ldots \ldots \ldots \ldots \ldots \ldots \ldots \ldots \ldots \ldots \ldots \ldots \ldots$

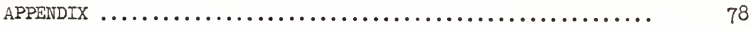

IIST OF REFERENCES $\ldots \ldots \ldots \ldots \ldots \ldots \ldots \ldots \ldots \ldots \ldots \ldots \ldots \ldots \ldots \ldots \ldots \ldots \ldots \ldots$

BIOGRAPHICAL SKEICH $\ldots \ldots \ldots \ldots \ldots \ldots \ldots \ldots \ldots \ldots \ldots \ldots \ldots \ldots \ldots \ldots \ldots \ldots \ldots \ldots$ 


\section{LIST OF TABLES}

Table

1. Monthly precipitation for the hot savanna region of

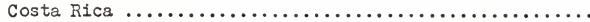

2. Extreme temperatures, relative humidity and sunshine

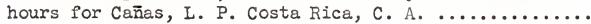

3. Yields of oven-dry jaraguagrass forage during the dry

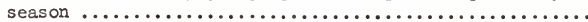

4. Yields of oven-dry jaraguagrass roots during the dry

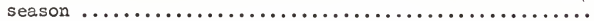

5. Fertilizer nitrogen recovered in oven-dry jaraguagrass forage during the dry season $\ldots \ldots \ldots \ldots \ldots \ldots \ldots \ldots \ldots$

6. Yields of oven-dry jaraguaerass forage regrowth

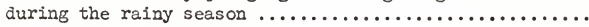

7. Nitrogen concentrations in oven-dry jaraguagrass

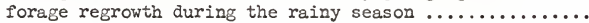

8. Total nitrogen contents of oven-dry jaraguagrass forage regrowth during the rainy season ..............

9. Crude protein concentrations in oven-dry jaraguagrass forage during the dry season $\ldots \ldots \ldots \ldots \ldots \ldots \ldots \ldots \ldots$

10. Total crude protein contents of oven-dry jaraguagrass forage during the dry season $\ldots \ldots \ldots \ldots \ldots \ldots \ldots \ldots \ldots$

11. Crude protein concentrations in oven-dry jaraguagrass forage regrowth during the rainy season $\ldots \ldots \ldots \ldots \ldots \ldots$

12. Cellulose concentrations and in vitro cellulose digestion of oven-dry jaraguagrass forage during

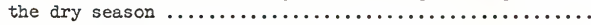

13. Profile descriptions of the soil of the experimental area 
14. Physical properties of soils $\ldots \ldots \ldots \ldots \ldots \ldots \ldots \ldots \ldots$

15. Chemical properties of soils $\ldots \ldots \ldots \ldots \ldots \ldots \ldots \ldots \ldots \ldots$

16. Analysis of variance for yields of oven-dry jaraguagrass forage during the dry season $\ldots \ldots \ldots \ldots \ldots \ldots \ldots \ldots \ldots$

17. Nitrogen concentrations in oven-dry jaraguagrass forage during the dry season $\ldots \ldots \ldots \ldots \ldots \ldots \ldots \ldots \ldots$

18. Total nitrogen contents of oven-dry jaraguagrass forage during the dry season $\ldots \ldots \ldots \ldots \ldots \ldots \ldots \ldots \ldots$

19. Analysis of variance for nitrogen concentrations in oven-dry jaraguagrass forage during the dry season .....

20. Analysis of variance for total nitrogen contents of oven-dry jaraguagrass forage during the dry season .....

21. Nitrogen concentrations in oven-dry jaraguagrass roots

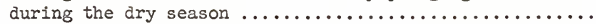

22. Total nitrogen contents of oven-dry jaraguagrass roots

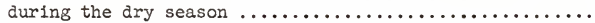

23. Phosphorus concentrations in oven-dry jaraguagrass forage during the dry season $\ldots \ldots \ldots \ldots \ldots \ldots \ldots \ldots \ldots$

24. Analysis of variance for phosphorus concentrations in oven-dry jaraguagrass forage during the dry season .....

25. Total phosphorus contents of oven-dry jaraguagrass forage during the dry season $\ldots \ldots \ldots \ldots \ldots \ldots \ldots \ldots \ldots$

26. Analysis of variance for total phosphorus contents of oven-dry jaraguagrass forage during the dry season ..

27. Phosphorus concentrations in oven-dry jaraguagrass roots

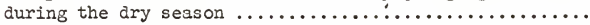

28. Total phosphorus contents of oven-dry jaraguagrass

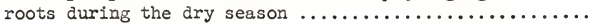

29. Analysis of variance for yields of oven-dry jaraguagrass forage during the rainy season $\ldots \ldots \ldots \ldots \ldots \ldots \ldots \ldots \ldots$

30. Analysis of variance for nitrogen concentrations in oven-dry jaraguagrass forage during the rainy season ... 
31. Analysis of variance for total nitrogen contents of oven-dry Jaraguagrass forage during the rainy season ...

32. Analysis of variance for cellulose concentrations in oven-dry jaraguagrass forage during the dry season .....

33. Analysis of variance for in vitro cellulose digestion of oven-dry jaraguagrass forage during the dry season .....

34. Potassium concentrations in oven-dry jaraguagrass

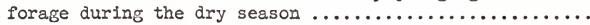

35. Calcium concentrations in oven-dry jaraguagrass

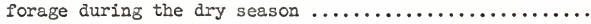

36. Magnesium concentrations in oven-dry jaraguagrass forage during the dry season $\ldots \ldots \ldots \ldots \ldots \ldots \ldots \ldots \ldots \ldots$.

37. Phosphorus concentrations in oven-dry jaraguagrass forage regrowth during the rainy season $\ldots \ldots \ldots \ldots \ldots \ldots$.

38. Potassium concentrations in oven-dry jaraguagrass forage regrowth during the rainy season $\ldots \ldots \ldots \ldots \ldots . . .$.

39. Calcium concentrations in oven-dry jaraguagrass forage regrowth during the rainy season $. . . \ldots \ldots \ldots . . .$.

40. Magnesium concentrations in oven-dry jaraguagrass forage regrowth during the rainy season ............... 
LIST OF FIGURES

Figure

1. Map of Costa Rica showing location of the Enrique Jimenez Nuñez Agricultural Experiment Station, Taboga, Guanacaste, and different weather stations in the

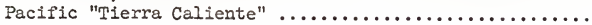

2. Effects of nitrogen fertilization and days of growth on the nitrogen concentrations in oven-dry jaraguagrass forage during the dry season $\ldots \ldots \ldots \ldots \ldots \ldots \ldots \ldots \ldots$

3. Effects of nitrogen fertilization and days of growth on the total nitrogen contents of oven-dry jaraguagrass forage during the dry season $\ldots \ldots \ldots \ldots \ldots \ldots \ldots \ldots \ldots$.

4. Relationships between the total nitrogen contents of oven-dry jaraguagrass shoots and roots during the dry season

5. Effects of nitrogen fertilization and days of growth on the phosphorus concentrations in over,-dry jaraguagrass forage during the dry season $\ldots \ldots \ldots \ldots \ldots \ldots \ldots \ldots \ldots$

6. Effects of nitrogen fertilization and days of growth on the total phosphorus contents of oven-dry jaraguagrass forage during the dry season $\ldots \ldots \ldots \ldots \ldots \ldots \ldots \ldots \ldots$

7. Relationships between the nitrogen and phosphorus concentrations in oven-dry jaraguagrass forage during

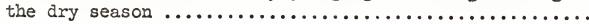

8. Relationships between the total nitrogen and total phosphorus contents of oven-dry jaraguagrass forage during the dry season $\ldots \ldots \ldots \ldots \ldots \ldots \ldots \ldots \ldots \ldots \ldots$

9. In vitro cellulose digestion of oven-dry jaraguagrass forage at different fermentation periods 


\section{INTRODUCTION}

The potential for cattle production in the tropics is probably greater than in other parts of the world. The availability of space, high radiation energy level, and good temperature throughout the year are environmental factors which are more favorable for forage growth in the tropics than in temperate climates. However, seasonal growth of pastures and fluctuations in their nutritive value, especially during long drought periods in the sub-humid, semi-arid and arid regions of the tropics, put a certain limitation on the improvement in the output of high quality forage to provide cattle feed above the maintenance requirements.

Tropical grasses are well adapted to their environment and their productivity and nutritive value can be improved by fertilization in most cases. Nitrogen (N) and phosphorus (P) are probably the most deficient elements in tropical grasslands. Forage concentrations of these elements are also critical in the nutritive value of the forage and animal performance. However, the total annual rainfall and its distribution pattern have a tremendous influence on the tropical environment which can affect pasture growth and composition, even at high levels of soil fertility. . There is a need for more information about the interaction of climatic and soll fertility factors in tropical environments in order to develop management practices to improve agricultural production and to increase food supply in the dry tropics. 
The present investigation was designed to study the movement of nutrients from jaragtagrass (Hyparrhenia rufa (Nees) Stapf) as affected by nitrogen fertilization and soil moisture stress during the dry season in a hot savanna. The effects of harvest dates and residual nitrogen from the fertilizer applied at the end of the rainy season on forage regrowth after the dry season were also investigated. In addition, the nutritive value of the forage sampled during the dry and rainy seasons was evaluated in terms of crude protein, mineral composition, cellulose concentrations and in vitro cellulose digestion. 


\section{REVIEW OF LITERATURE}

Davies and Skidmore (36) indicated that problems of grazing animals in the tropics arise from the fact that the field environment is difficult or sometimes impossible to change. They emphasized the importance of forage production in relation to seasonal growth of pastures, and to the nutrition and health of the grazing animals. Some tropical pasture species seem to be well adapted to extreme environmental conditions; however, their potential to supply adequate feed for cattle production may be limited not only by soil fertility but also by their mechanism of adaptation.

The Tropical Grass

Hyparrhenia rufa (Nees) Stapf has been described by Whyte, Moir and Cooper (132) as a densely tufted, perennial grass with basal leaves forming large tussocks when ungrazed. It is indigenous to tropical Africa where it is dominant over large areas particularly on heavy dark clay soil, under sub-humid and semi-arid conditions. They indicated that the grass is drought resistant but susceptible to frost. Saens-Maroto (101) indicated that the grass is known in Brazil by capim jaragua or jaragua, capim provisori, capim vermelho, sape gigantee, and pasto roxo; in Colombia by yaragua, yaragua or puntero and in Costa Rica by jaragua. McIlroy (74) refers to this grass in English as "jaragua grass." . 
Whyte et al. (132) mentioned that jaraguagrass was the most widespread pasture grass in tropical Central and South America. Boerendonk (10) reported this grass among the most common in the Cuban savannas. Kemp, MacKenzie and Romney (67) found the grass growing in British Honduras. Watkins and Chavez (127) recognized it as being important in infertile areas of $\mathrm{El} \mathrm{Salvador.} \mathrm{Hogaboom} \mathrm{(56)} \mathrm{indicated} \mathrm{its} \mathrm{presence} \mathrm{in}$ Honduras. Taylor (114) said that jaraguagrass was among the main species of pasture grasses in Nicaragua. Rey-Gonzales and Mata-Pacheco (97) indicated that it is predominant in the Pacific lowland of Costa Rica. Ramia (96) and Fontana (46) in Venezuela, Espinal (41) in Colombia, Muro and Agreda (82) in Perd, Pastore and Thomson (88) in Paraguay and Braun (13) in Bolivia, indicated that jaraguagrass was an introduced forage species which occurs in those countries under dry tropical conditions. Jaraguagrass is very popular in the tropics because of its adaptation to dry conditions, resistance to fire, and good production of viable seed.

\section{Savanna Soils and Their Fertility}

Nye and Greenland (85) recognized in Africa the poor physical properties of soil developed under savanna as compared to forest. They reported that a typical analysis of savanna soil in Africa indicated nitrogen and phosphorus deficiencies and sometimes low exchangeable bases, although potassium rarely became deficient. The soil $\mathrm{pH}$ was usually above 5.0. Smith (106) mentioned that lack of nitrogen was the limiting factor in herbage production in Southern Rhodesia. Brockington (20) found that nitrogen was a serious limiting factor in plant growth on the reddishbrown clay soils of Central Africa. Phosphorus was also deficient but 
potassium and calcium had little effect on growth of the Hyparrhenia dominant savanna.

Coaldrake (3l) made the observation that the quantities of plant nitrogen in many of the natural tropical grasslands were large with little or no assistance from legumes. However, the concentration of nitrogen in the grass was not enough to support cattle production without the assistance of legumes or fertilizer nitrogen. Botha (1I) explained that the increase in total soil nitrogen of the grass plot in his experiments with Eragrostis curvula Nees was due to non-symbiotic fixation of atmospheric nitrogen in the presence of readily oxidable organic matter. Birch (7) indicated that the nitrogen availability in tropical soils in Africa depended on decomposition of organic matter. He observed that decomposition increased with air-drying of the soil. Hagenzieker (52) found in tropical Africa that there was an increase in mineral nitrogen at the beginning of the rainy season following a long ary season but it did not last more than 6 weeks. Greenland (49) reported that the period of most rapid nitrate increase in tropical soils was at the start of the rains following a dry season. However, Hardy (53) indicated that the fluctuation in soil nitrate between the wet and dry seasons was never very marked under pasture in tropical conditions. Theron (115) in Africa found that nitrification was entirely repressed under Hyparrhenia grass the second season after its establishment. This phenomenon was explained by Meiklejohn (76) in Ghana who said that "the most striking microbiological difference between forest and grassland soils is the lack of nitriteoxidizing bacteria in grassland." However, Martin (72) indicated that nitrification might play a small role in the nitrogen nutrition of 
permanent pastures in the tropics and that grasses can absorb this element almost entirely as amonium. The potential for good pasture production in the tropics depends not only on the fertility of grassland soils but also on those factors affecting uptake and nutrient utilization by the forage plant throughout the year.

\section{Response of Tropical Grasses to Fertilization}

\section{Dry matter}

Walker (125) emphasized the high capacity of grasses to utilize nitrogen. The response of tropical grasses to nitrogen fertilization in terms of dry matter production was approximately linear to annual rates of $400 \mathrm{~kg}$ of the element per ha, provided that the moisture supply was adequate. Vicente-Chandler et al. (12l) obtained annual yields of over $40,000 \mathrm{~kg}$ of good quality oven-dry forage per ha with heavy fertilization in the humid tropics of Puerto Rico. However, the yields were much lower in the semi-arld part of the country (119). Brockington (20) found that splitting the nitrogen fertilizer application, with the addition of superphosphate, resulted in linear yield response up to $200 \mathrm{~kg}$ nitrogen per ha per year with a Hyparrhenia dominant grassland in Northern Rhodesia. However, Smith (107) working in the same Hyparrhenia veld found no advantage in splitting the fertilizer in the first two years of application. All the fertilizer was applied at the start of the rainy season. Noland, Broce and Vergara (84) reported that the dry matter yield of jaraguagrass increased $70 \%$ by application of $800 \mathrm{~kg}$ per ha of a 10-30-10 fertilizer at the beglnning of the rainy season. They increased yields of jaraguagrass in Panama by $58 \%$ with the application of about 
$200 \mathrm{~kg}$ nitrogen per ha.

Burgos ', working with two dark clay soils from a savanna of the interior of Honduras, reported that those soils did not respond to nitrogen fertilization until a sufficient supply of phosphorus was available to the plants. Blue? working with tropical grasses at Liberia, Costa Rica, reported good response to the application of nitrogen and phosphorus. Yields increased linearly with applications to $60 \mathrm{~kg}$ of nitrogen per ha per harvest; excellent yield response was obtained with application of 30 kg phosphorus per ha, but no response to potassium was obtained.

It is possible to fertilize the grass before the dry season and insure adequate moisture for forage growth. This forage could be harvested for hay or for "deferred grazing" during the dry season. Russell (100) recommended application of nitrogen to grasses at the very end of the rainy season to raise the protein concentrations of the dry season growth. He also indicated that standing dry fodder will have a higher protein content. Andrade et al. (2) Indicated that for the savanna region of Costa Rica the fertilizer should be applied during the first half of october. Blue ${ }^{2}$ reported results from field experiments on the effect of fertilizer applied at the end of the rainy season on forage yields of three tropical grasses left standing in the field for dry season grazing. These experiments were conducted in the hot savanna of costa Rica. The fertilization consisted of $55 \mathrm{~kg}$ nitrogen per ha with phosphate

$I_{\text {Burgos, C. F. 1967. Nitrogen-phosphorus interaction in two dark clay }}$ soils from Eonduras. Ph.D. Thesis. University of Florida, Gainesville. Blue, W. G. 1960. Fertilization experiments with grass pastures in Costa Rica. Final report of assingment to Costa Rica under the University of Florida/STICA contract. University of Florida, Gainesville. 
and potash to give a 2-1-1 ratio, and the samples were taken on December 18. In general, the areas fertilized on October I gave higher forage yields compared to no fertilization. Jaraguagrass and buffelgrass (Cenchrus ciliaris L.) produced 6,068 and 4,709 kg oven-dry forage per ha with fertilization compared to 4,582 and 3,309 kg per ha, respectively, Argentine bahiagrass (Paspalum notatum Flugge) produced lower yields compared to the other two grasses. He reported, in another experiment designed to determine the effect of rates of nitrogen fertilization and the dry season on yields of forage left standing in the field for dry season grazing, that jaraguagrass yields harvested on December 18 increased from 4,486 to $6,468 \mathrm{~kg}$ oven-dry forage per ha for the $41 \mathrm{~kg}$ nitrogen per ha treatment. Subsequent harvests on January 26 and March 11 showed little change in forage yields. Blue ${ }^{2}$ also reported a significant interaction between the days of growth and nitrogen treatments.

Brockington (21), working with several tropical grasses in Northern Rhodesia, found little response to complete fertilization with nitrogen, phosphorus and potassium during the dry season. The highest total dry matter production for the dry season was 2,500 and 2,135 kg per ha for Eragrostis curvula Ness and cynodon plectostachyus (K. Schum) Piler, at the hay stage, respectively. Yields as low as $396 \mathrm{~kg}$ dry matter per ha were obtained with Chloris gayana Kunth at the same stage of growth. The yields were consistently smaller for all the grasses harvested at grazing stage, which emphasized leaf production. The lower yields obtained in Northern Rhodesia compared with those obtained in Costa Rica were probably due to less water available for forage growth at the beginning of the dry season. 


\section{Crude protein}

The tropical grass species discussed by oyenuga (87) were low in crude protein when compared with temperate grasses at similar stages of growth. However, Schofield (102) found marked differences in protein concentrations between various tropical species under the same soilclimatic conditions in Queensland, Australia. He reported that the crude forage protein varied from 5.2 to $14.9 \%$, on the dry-weight basis. Cartmill (27) indicated that the crude protein of native grass in Queensland, Australia ranged from 8.8 to $13.0 \%$ when samples representing the part actually ingested by the ruminant were obtained.

Edward and Bogdan (40) found that the crude protein concentrations of jaraguagrass in Kenya was $14.3 \%$ after three weeks of growth. They pointed out that, at this stage, the dry matter produced would be insufficient for grazing or cutting. Jardim et al. (62) reported that the crude protein content of jaraguagrass in Brazil was as high as $11.8 \%$ at the end of the rainy season. French and chaparro (44) found that the crude protein content of jaraguagrass in Venezuela varied from 1.4 to $7.3 \%$ during the dry season. Watkins and Lewy-van Severen (128) mentioned that the average crude protein of jaraguagrass cut every three months throughout the year was 3.9\%. They also indicated that this grass had the lowest crude protein of all troplcal specles examined. Miller, Rains and Thorpe (80) also found that the crude protein concentration of jaraguagrass was lower that any other grass silage in Northern Nigeria. Brendon and Eorrell (16) reported similar results from Uganda.

It is possible to increase the crude protein concentrations of tropical forage by nitrogen fertilization, provided that water is not a 
limiting factor. Vicente-Chandler, Silva and Figarella (120) found that the protein concentrations and contents of Guineagrass (Panicum maximum Jacq.) in Puerto Rico increased with nitrogen applications to 1,790 $\mathrm{kg}$ per ha divided into several applications throughout the year. The crude protein of the grass averaged $9.6 \%$. Caro-Costas, Vicente-Chandler and Figarella (24) later reported average crude protein concentrations of heavily fertilized grass in Puerto Rico as high as 18.1\%. Both experiments were conducted in the humid region of Puerto Rico. Pedreira et al. (90) found that the crude protein of jaraguagrass in Brazil increased from 7.7 to $9.4 \%$ when fertilized with nitrogen, phosphorus, potassium and micronutrients, after application of lime. Blue ${ }^{2}$ reported that the crude protein of Jaraguagrass in the hot savanna of Costa Rica increased to $9.5 \%$ during the rainy season with application of $210 \mathrm{~kg}$ nitrogen per ha and to $9.4 \%$ when fertilized with $120 \mathrm{~kg}$ nitrogen per ha at the end of dry season. However, the effect of nitrogen fertilization on crude protein concentrations of the forage did not last beyond the middle of the dry season.

The protein concentrations of tropical grasses follow a marked seasonal pattern tending to decrease during the dry season, regardess of nitrogen fertilization. Brendon and Horrell (15) indicated that all the grasses studied in Uganda showed a considerable decrease in the protein from the beginning of the rains to the end of the dry season. Lansbury, Innes and Mabey (69) found that the protein concentrations of grass in Ghana fell from $13.0 \%$ after the first rains to $3.4 \%$ during the ary season. They also indicated that the protein concentrations 
of herbage decreased rapidly as the plant matured; however, the total of protein content did not decrease in any case. Todd (116) reported that the crude protein in grasses in Kenya decreased from 15 to $20 \%$ at the beginning of the rainy season to 4 to $5 \%$ during the dry season. Oyenuga (87) observed that the decrease in the crude protein concentrations of the forage was more marked in some tropical grass species than in others. Pennisetum purpureum Schumach appeared to contain more protein than any other grass observed in Nigeria.

Weinmann (129), working with Chloris gayana Kunth, a tropical grass, found that considerable amounts of nitrogen, phosphorus and potassium were lost from the shoots after flowering and seed formation. He worked with pots and was able to recover large amounts of these elements in the roots. He explained that in addition to translocation from shoots, nitrogen and mineral elements also accumulated in the roots to a certain extent by simultaneous absorption from the soil.

Andrade et al. (2) working with jaraguagrass under field conditions in the savanna region of Costa Rica found that protein declined in the forage during the dry season. They indicated that since there was no rain to have leached protein from the leaves and no appreciable loss of leaves from the plant took place, nitrogen must have been translocated to the roots under the unfavorable growth conditions of soil molsture stress. However, they did not present root data to support their suggestion of nitrogen translocation.

\section{Minerals}

The mineral concentration of tropical grass varies with the species and mineral content of the soil. In general, phosphorus is low for most 
of the tropical region of the world. Schofleld (103) reported forage concentrations between 0.09 and $0.34 \%$ phosphorus in tropical Australia. The calcium concentrations of the grasses varled from 0.22 to $0.50 \%$ in the same region. Howard and Burdin (59) found that in Kenya the phosphorus levels of grasses varied from 0.07 to $0.25 \%$; calcium levels between 0.30 and $0.61 \%$; magnesium approximately $0.18 \%$; and potassium varied from 0.98 to $3.12 \%$, on the oven-dry basis. They also reported significant correlations between the crude protein and minerals, except for calcium. French and Chaparro (44) indicated that the phosphorus concentrations of jaraguagrass during the dry season in Venezuela varied from 0.02 to $0.11 \%$, calcium from 0.27 to $0.42 \%$, potassiun 0.22 to $0.87 \%$ and magnesium 0.17 to $0.46 \%$. There was no apparent correlation between crude protein and minerals. Jones (63) presented data for the mineral concentration in several grasses from a Hyparrhenia dominant grassland in Northern Rhodesia. Phosphorus varied from 0.06 to $0.21 \%$, calcium from 0.23 to $0.63 \%$, potassium from 0.53 to $2.25 \%$ and magnesium from 0.07 to $0.27 \%$, from growth throughout the year. He also showed figures for sodium, sulfur and chlorine. The phosphorus and potassium contents of cultivated grasses grown in the same region were low for the ary season and similar to the unfertilized native grass (Jones (64)).

Awan (4) in Honduras reported an increase in the phosphorus concentration of jaraguagrass from 0.15 to $0.39 \%$ with application of $35 \mathrm{~kg}$ phosphorus per ba at the beginning of the rainy season.

\section{Fertilizer nitrogen recovery}

Martin and Skyring (73) pointed out that the recoveries of fertil1zer nitrogen from growing crops seldom exceeded 50\%. Furthermore, the 
succeeding crops usually do not utilize more than an additional $10 \%$. The residual nitrogen may be inmobilized in the organic form or lost by leaching, erosion of volatilization. Henzell (55) said that a nitrogen recovery of 50 to $75 \%$ could be regarded as very satisfactory for grasses. He mentioned that the range for tropical conditions was from 10 to $88 \%$. Blue et al. (9) reported a recovery of more than $100 \%$ with pangolagrass (Digitaria decumbens Stent) from the humid region of Costa Rica. However, the recovery with elephantgrass (Pennisetum purpureum Schumach) was about 10\%. They could not find any explanation for this difference other than differences in species and growth habit. Smith (105) found that the recovery with Hyparrhenia veld was about 40\% in Northern Rhodesia. Dilz and Woldendorp (38), working with $15 \mathrm{~N}$ concluded that under field conditions a substantial part of the fertilizer nitrogen may be tied up in the organic nitrogen cycle in roots and soil.

\section{Plant Metabolic Responses to Droughts}

The first effect at the beginning of the drought is decreased photosynthesis associated with increased respiration. The decrease in photosynthesis, according to Levitt $(70)$, is due to stomatal closure and decrease in the rate of diffusion of carbon dioxide through the dry mesophyll of the leaf. Since photosynthesis decreases, respiration tends to increase to maintain the energy balance of plant metabolism.

\section{$\underline{\text { Root growth }}$}

Root growth is favored more than shoot growth when the. soil becomes drier, and the first effect of the drought is an increase in the root: shoot ratio. Troughton (178) indicated that the changes in the 
environment may be interpreted as tending to maintain a balance between the photosynthesis in the shoots and the activity of the roots. Oppenheimer (86) reported that the root: shoot length relations were 3.5:1 to 6.0:1 in xerophytic grasses compared to less than 3.0:1 in the more mesophytic ones. This response is probably due to the fact that the carbohydrate reserves of the plant, which are the source of energy and metabolic water during respiration, are greater in the roots compared to the shoots. Soil aeration, temperature and availability of moisture at the deeper horizons will also influence root growth. However, root distribution studies indicate that the majority of grass roots occur in the upper layer of soil. Gwynne (51) indicated that pangolagrass had more than $75 \%$ of its roots, on a dry-weight basis, concentrated in the top $30 \mathrm{~cm}$ of soil, while corn had $98 \%$ and sugar cane over $85 \%$ in the top $61 \mathrm{~cm}$ of soil.

The absorption of nutrients by the roots is affected by soil moisture. Volk (123) found increases in nitrogen and potassium intake with plants growing in soil at below the wilting point. There was very little increase in phosphorus intake. Stocker (113) indicated that in general, plants grown under ary conditions showed an increase in nitrogen uptake and a decrease in potassium uptake. The data for phosphorus, calcium and magnesium are not sufficiently clear to draw conclusions. However, Gates (47) reported that during wilting the uptake of nitrogen and phosphorus by tomato plants was noticeably reduced. Wilting depressed phosphorus concentration more than nitrogen. Williams (133) found no fundamental physiological difference between the seminal and adventitious root system grasses. He pointed out that translocation of nutrients from the roots 
ceases when flowering occurs. The increase in weight of roots growing under soil moisture stress compared to shoots can be explained, in part, by the increase in nutrient absorption from the soil and diminished nutrient translocation to the shoots. However, it does not mean that nutrients from the shoots can not be translocated back to the roots when environmental conditions are unfavorable for shoot growth.

Weinmann (130) mentioned that the fertilizer nitrogen stimulated top growth more than root growth in forage plants. However, Troughton (117) indicated that it appeared that plants grown in conditions of low available nitrogen had well-developed root systems compared to shoot growth. Weinmann (131) found later that the nitrogen content of roots was higher when nitrogen was applied.

It is possible that the root growth in response to fertilizer will have a maximum determined by the physical characteristics of the soil. Holt and Fisher (57) reported that under high nitrogen fertilization the accumulation of roots remained at a fairly constant level while forage production increased in response to the fertilizer.

\section{Nitrogen metabolism}

Hegarty (54) mentioned in 1962 that there was little information available on the effect of the tropical environment on the metabolic processes of tropical grasses. However, information available about effect of drought on plant metabolism from other regions can be useful in tropical conditions, provided that low temperature is not a factor.

Petri and wood (92) working with two grasses, Phalaris tuberosa L. and Lollum multiflorum Lam. suggested that the net rate of protein formation from amino acids decreased with reduction of water content in the 
leaf. They also mentioned (93) that decreasing water content could lead to protein hydrolysis and decrease protein synthesis in the leaves. Stocker (113) explained that hydration stabilizes the existing protein structure. The protoplasmic structural changes during the drying of the environment are due to shrinking of hydrophylic groups of protein molecules which leads to mechanical tensions and exposure of bonds. This results in breaking of bonds, and tearing and loosening of the structure. He mentioned that this phenomenon usually occurs between 30 and $40 \%$ of the field capacity of the soil, depending upon the rate of drying. The proteosis of the leaf protein leads to an increase of soluble nitrogen compounds of low molecular weight which can migrate to the more metabolicly active parts of the plant. McKee (75) indicated that protein in older leaves of annual plants is hydrolysed and the products are translocated to other parts of the plant. Chen, Kessler and Monselise (30) found that the total nitrogen level in the upper parts of citrus seedlings increased at the same time that it decreased in the roots during the period of water stress. These reports seem to indicate a different pattern for movement of nitrogen during water stress on annual and perennial plants. A different pattern of movement between dicotyledons and grasses is also possible.

Kemble and Macpherson (66) working with perennial ryegrass(Lolium perenne I.) found that all the nitrogen from the degraded protein reappeared as $\alpha$ amino acids, volatile base amides or peptides upon wilting after cutting. Barnett and Naylor (5) reported that amino acids were synthesized in bermudagrass (Cynodon dactylon (L.) Pers.) during water stress but at the same time protein synthesis was inhibited and protein levels 
decreased. They also found accumulations of free proline and free aspargine, increases in levels of valine and glutamic acid and a decrease in alanine levels in the shoots. However, they did not discuss the movement of these compounds from the shoots to the roots.

Shah and Loomis (104) found that the relative concentration of RNA and protein decreased in sugar beets (Beta vulgaris) as the stress condition developed during arought. Kessler (68) reported an initial rise in RNA content in higher plants followed by a decrease over a period of arought. DNA synthesis was also diminished. He explained that the protein hydrolysis during wilting was the result of decrease in RNA content. There is little information about the role of RNA on maintenance of protein structure during wilting and any effect on protein systhesis may be reflected by the accumulation of amino acids and peptides. This accumulation could be interpreted as the result of protein hydrolysis. The metabolism of nitrogen in the plant could result in losses by volatilization, leaching or excretion through the roots. Pearsall and Billimoria (89) reported nitrogen volatilization from leaves floating on nutrient media with nitrates. No losses were observed when organic sources of nitrogen were used. However, Allison et al. (1) found no significant gaseous losses from leaves under any condition when organic and inorganic sources of nitrogen were used. Viets (122) indicated the possibility of nitrogen losses by volatilization from plants. However, he mentioned that nitrogen losses from the plant by leaching were not generally regarded as significant. McKee (75) suggested excretion of nitrogenous substances through the roots as a possibility for losses from green plants. Katnelson, Rouatt and Payne (65) reported that it was the 
case with cereals grown on sterile sand-soil misture. In any case the nitrogen losses from the plants by different mechanisms were not sufficient to affect the total nitrogen content of the plant.

\section{Phosphorus metabolism}

Phosphorus and nitrogen metabolism in plants are closely associated and Stocker (113) indicated that changes in the metabolism of one of these elements will also affect the other. Weinmann (131) concluded that nitrogen and phosphorus were translocated from the shoots to the roots of grasses under unfavorable growth conditions. However, he did not show a direct relationship between the movement of these two elements. Andrade et al. (2), working in the savanna region of Costa Rica, did not present data on the phosphorus status of jaraguagrass during the dry season.

\section{Tropical Forage Quality}

Milford and Minson (78) stated that the feeding value of a forage plant is determined by the quantity of dry matter produced. The nutritive value of the forage is largely determined by the crude protein and energy contents. The mineral composition and vitamin supplies are also important, especially under grazing, but these comporents can be supplied so easily that little attention is given to them unless deficiencies appear in the cattle. However, the best indication of the relative nutritive value of

a forage is animal performance.

\section{Crude protein}

Glover, Duthie and French (48) suggested that the total crude protein concentration in the feed, irrespective of its nature, determines the 
digestibility of the protein by ruminants. They based this observation on analysis of the results presented on 597 records of digestibility trials of herbages and mixed feeds with cattle and sheep of different breeds in many parts of the world, including the tropics. There is a direct relationship between the crude protein concentration in the forage and the apparent digestible crude protein by minants as indicated by the following equations calculated with digestibility trial data for temperate and tropical grasses.

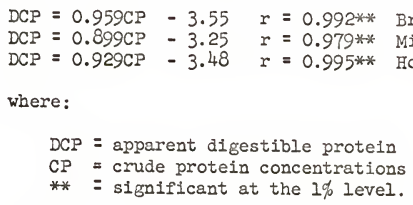

These three equations are similar and the correlation coefficients are highly significant regardless of the type of animal and feed used in the digestibility trials. These equations suggest a critical value of about $3.6 \%$ crude protein in the forage; below this value the apparent digestible crude protein is essentially negative for practical purposes. The optimum levels of crude protein for normal growth of cattle are 9 to $11 \%$ which will result in 5.6 to $7.5 \%$ digestible protein according to the National Research Council (50). French, Glover and Duthie (45) indicated that these general equations could be used in the tropics to compute maintenance and production rations for meat and milk. They also indicated that the standard procedure for determination of digestible crude protein is time consuming and not suited to the rapid change in chemlcal composition of herbages under dry tropical conditions. 
Crude protein concentration of the forage may have an effect on forage intake; however, Milford and Minson (78) reported that crude protein of tropical grasses had no effect on forage intake if it were above $7 \%$. A decline in intake occurred below that level. Bedrak et al. (6) reported that heifers fed protein deficient rations showed decreased appetite, lower rate of gain, lower rate of reproduction, and lower hemoglobin and hematocrit blood values, compared with those fed adequate protein levels. The levels of crude protein in the grass for animal production in the tropics is extremely important since cattle obtain most of their nutrients from forage under grazing.

\section{$\underline{\text { Energy }}$}

Organic matter digestibility is the method most widely used for comparing the nutritive values of the energy in tropical forages. Milford and Minson (78) pointed out that there are no figures available for net energy values of tropical pastures. However, Moir (81) reported that the correlation between digestible energy concentration and dry matter digestibility of forage in Australia was highly significant. Butterworth (22) indicated the same relationship for some tropical forages in Trinidad. Both authors calculated equations as follow:

$$
\begin{array}{ll}
Y=0.0467 X-0.192 & \text { Moir (81) } \\
Y=0.0418 x+0.219 & \text { Butterworth (22) }
\end{array}
$$

where:

$$
\begin{aligned}
& Y=\text { digestible energy in } k c a l \text { per } g \\
& X=\text { coefficient of organic matter digestibility. }
\end{aligned}
$$

Naga and el-Shazly (83) found a highly significant correlation between in vivo and in vitro cellulose digestion for grasses but not for 
legumes in Egypt. They reported highly significant correlations for grasses only between in vivo cellulose digestion and digestible energy, and between the in vitro cellulose digestion and digestible energy. In vitro cellulose digestion is a good measure of the energy value of forage grasses because of the general simplicity of the method and small weight of sample involved. It can be very useful in pasture programs to evaluate forage species and management, although the interpretation of the results can be misleading if other factors, such as voluntary intake by the animals, are not taken into consideration.

French (43) found that the dry matter digestibility coefficient of several species ranged between 51.1 and $72.8 \%$ depending on stage of growth. Marshall and Long (7I) indicated that the dry matter digestibility coefficient of some East African grass hays varied between 45.6 and $70.6 \%$, depending on the species. Both reports were based on digestibility trials. Da Silva, Conrad and Campos (35) mentioned that the in vitro cellulose digestion of some forage plants in Brazil decreased from $88 \%$ to $72 \%$ as the cellulose concentration increased from 32.8 to 39.3\%. Their results were based on 48-hr fermentations and seem to be relatively high compared to the results of digestion trials mentioned above.

Smith (106) indicated that the digestibility of organic matter in a Hyparrhenia veld in Africa declined from 50 to $38 \%$ as the grass matured; fertilization increased digestibility by $10 \%$. Jardim (6I) reported from Brazil that the digestibility of jaraguagrass decreased from $56.6 \%$ at a young stage to 42.7\% after flowering. However, Miller and Rains (79) found that in Nigeria the digestibility of jaraguagrass determined at 
preflowering stage, in the middle of the rainy season, was only $39.6 \%$. This value was lower than that of any other grass studied. Butterworth (22) studied the digestible energy content of some tropical forages in Trinidad using sheeps and a bomb calorimeter to determine energy values of feeds and feces. He found that gross energy varied from 4.13 to 5.02 kcal per $g$ dry matter and digestible energy varied from 2.23 to $3.20 \mathrm{kcal}$ per $B$ dry matter. Marshall and Long (71) reported in similar studies in Africa that the eross energy of tropical pastures was between 4.02 and $4.21 \mathrm{kcal}$ per g dry matter and the digestible energy varied from 1.90 to $2.99 \mathrm{kcal}$ per $\mathrm{B}$. The energy value of jaraguagrass was lower than any other grass studied, in both cases. The low energy value of jaraguagrass can be compensated by the amounts of forage produced which could increase carrying capacity and weight gains per unit area.

\section{Animal Performance in the Tropics}

\section{Voluntary intake}

The feed consumption by cattle is limited by voluntary intake, provided that sufficient forage is available. Miller and Rains (79) reported that the relative intake of tropical forages in $\mathrm{Nigeria}$ averaged $1.5 \mathrm{~kg}$ of dry matter per $100 \mathrm{~kg}$ of body weight for cattle and 1.9 for sheep. However, the difference in intake did not take into consideration animal size. Milford and Minson (78) indicated that this can be corrected by expressing the results on the basis of unit metabolic size in terms of intake per $\mathrm{kg}^{0.73}$ of live weight. They showed that the intake of tropical Grasses varied with species and stage of maturity, and forage intake in Australia ranged from 22 to 928 per $\mathrm{kg}^{0.73}$ live weight per day. 
Weight gains

There are few reports of grazing trials in the tropics which indicate seasonal variations in the weight gains of cattle and performance with different grass species. Carrera and Ferrer (26) reported that the weight gains of Zebu animals in grazing trials with jaraguagrass in Mexico averaged 185 to $199 \mathrm{~kg}$ per ha per year over a two-year period. Carrera (25) indicated later that the steers grazing jaraguagrass showed the smaller rate of daily gain, $248 \mathrm{~g}$ compared to $550 \mathrm{~g}$ for pangolagrass, over a three-year period. Arroyo and Teunissen (3), working with Zebu steers in a put and take grazing trial in Mexico, found that the gains in weight from July to January varied with the forage species. The gains with jaraguagrass were $190 \mathrm{~kg}$ per ha, compared to 150 and $406 \mathrm{~kg}$ per ha. for guineagrass and pangolagrass, respectively. Carneiro et al. (23) in Brazil pointed out that the average daily weight gain per animal was 282 $g$ for the ary season compared to 528 g during the rainy season. The animals were on jaraguagrass pastures in both seasons but received some additional feed during the dry season.

Fertilization can influence animal performance in the tropics; however, it seems that seasonal variations prevail under all circumstances. Quinn et al. (95) reported that the daily weight gain of Zebu steers in central Brazil varied from 77 to $175 \mathrm{~g}$ with fertilized grasses compared to 4 to $40 \mathrm{~g}$ without fertilizer during the dry season. For the rainy season the variation was from 570 to $813 \mathrm{~g}$ with fertilization compared to 588 to $804 \mathrm{~g}$ without fertilization. They indicated that, combining the results for both seasons, the live weight gains per unit area for animals grazing on jaraguagrass were greater than any other grass with or without 
fertilization. With fertilization the Jaraguagrass produced $448 \mathrm{~kg}$ of live weight gain per ha and 249 without fertilization. However, the gains during the dry season were 5.7 and $0.3 \%$ of those during the rainy season with and without fertilization, respectively.

The inclusion of a legume in a grass sward can also influence animal performance under grazing in the tropics, but again the season of the year can be a limiting factor. Stobbs(111) found that the inclusion of Stilosanthes gracilis or Centrocema pubescens with three tropical grasses including jaraguagrass, increased annual live weight gains of Zebu cattle by 14 to $41 \%$. They stressed the value of the legume during the dry season which increased live weight from about 188 to about 470 $\mathrm{kg}$ per ha per year. Stobbs and Joblin (112) indicated later that the live weight gain of Zebu cattle in Africa increased from 289 to $401 \mathrm{~kg}$ per ha during the dry season and from 1599 to $1823 \mathrm{~kg}$ per ha during the rainy season when Centrocema pubescens was included with jaraguagrass pastures under grazing conditions. These reports seem to indicate that protein was probably the limiting factor for cattle performance and the legumes were able to provide it, even though there was a limitation in the availability of water during the dry season. 
DESCRIPTION OF THE HOT SAVANNAS OF COSTA RICA

The lowland savannas of Costa Rica are located in the northwest section of the country between latitude $10^{\circ} 00^{\prime}$ and $12^{\circ} 00^{\prime} \mathrm{N}$ and longitude $84^{\circ} 30^{\prime}$ and $86^{\circ} 00^{\prime} \mathrm{W}$, extending toward the southwest part of Nicaragua, Central America. It includes most of the Guanacaste Province and part of Puntarenas Province.

The region can be divided for descriptive purpose into the following distinctive physiographic areas, according to a geodetic survey prepared by the U. S. Army: 3

(a) Mainland. - It lies north, northwest and southeast of the Tempisque Valley and consist of a gently sloping pledmont leading to steep slopes of high volcanic mountains in the Cordillera Guanacaste.

(b) Tempisque Valley.- It is located northwest of the Gulf of Nicoya. It consists of a gently sloping, alluvial-filled depresion about $60 \mathrm{~km}$ long and $20 \mathrm{~km}$ wide, less than $50 \mathrm{~m}$ above sea level.

(c) Nicoya Peninsula.- This area is physiographically separated from the mainland by the Tempisque Valley and is maturely dissected into sharp ridges, peaks and V-shaped canyons with small coastal plains and narrow stream valleys.

3 Costa Rica. 1965. Recommendations on natural resources studies for development of Nicoya-Tempisque Region, Costa Rica. Report prepared for U.S.A.AID/Costa Rica by U. S. Army, Inter American Geodetic Survey. Natural Resources Division. Fort Clayton, Canal Zone. 14 p. 
Climate

The climate of the hot savanna resion of costa Rica is characterized by two distinctly divided seasons, rainy and dry. About $90 \%$ of the annual precipitation, 1400 to $2400 \mathrm{~mm}$, falls during the rainy season, from May through November. Rainfall data for different weather stations in the region shown in Fig. 1 are presented in Table 1. Cañas, Cañas La Pacifica and Iiberia are located in the Tespisque Valley, Esparta is located on the mainland and Santa Cruz is located on the Nicoya Peninsula.

The records suggest two maxima during the rainy season, one in June and another in September, and a very ary season from December through April.

Extreme temperatures, relative humidity and dafly sunshine hours for the weather station Cañas La Pacifica in Guanacaste Province are shown in Table 2. The average maximum temperature, $35.5 \mathrm{C}$, and the average minimum temperature, $21.0 \mathrm{C}$, fluctuate little during the year and do not seem to be influenced by the rainfall to any great extent. However, the temperatures are modified by elevation.

The relative humidity is high throughout the year with an average maximum around 95\% and a minimum around 55\%, reaching maxima of $100 \%$ during the rainy season. The average daily sunshine hours are around 6; however, less sunshine occurs during the rainy season due to heavy cloud cover.

The climate of this region is typical of the hot savannas of latin America which include the Bolivar savannas of Colombia, "Llanos" of Venezuela and Colombia, savannas of the Amazon basin and Guyana, savannas of Bolivia, Mato Grosso and the Gran Chaco, and the Cuban savannas, 

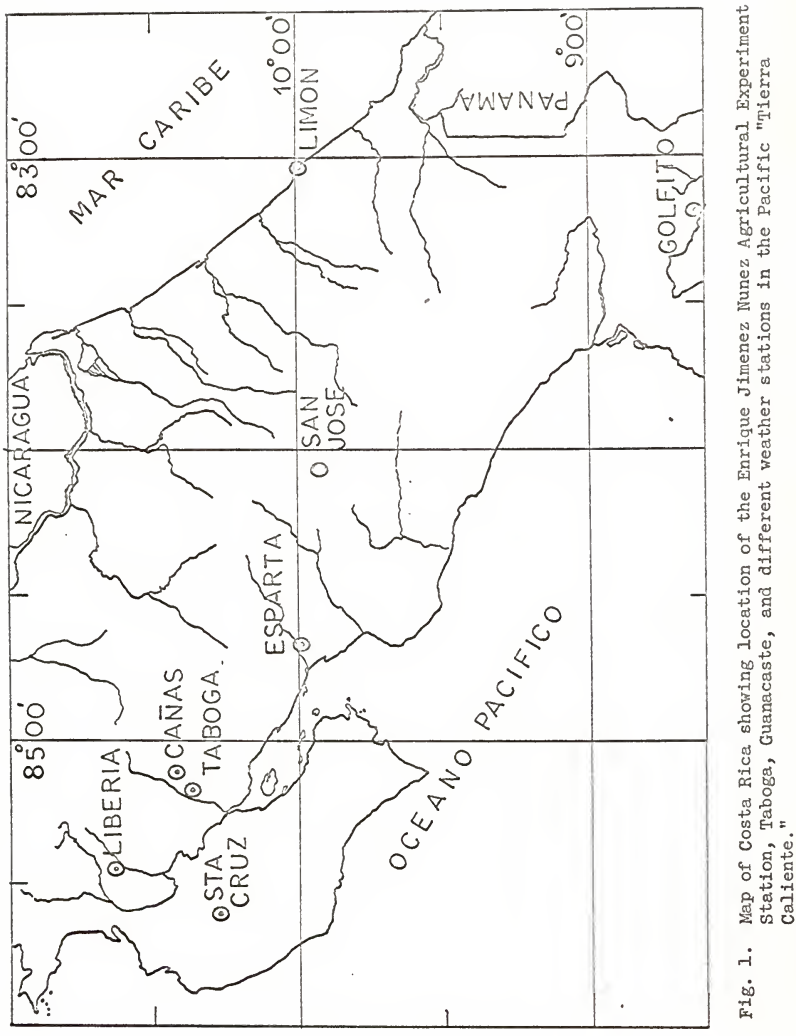
Table 1.- Monthly precipitation for the hot savanna refion of Costa Rica, C. A. I.

\section{Weather stations}

\begin{tabular}{lrrrrrr} 
Month & $\begin{array}{l}\text { Cañas } \\
1961-66\end{array}$ & $\begin{array}{l}\text { Cañas, L.P.3 } \\
1951-66\end{array}$ & $\begin{array}{c}\text { Liberia } \\
1951-66\end{array}$ & $\begin{array}{l}\text { Esparta } \\
1951-65\end{array}$ & $\begin{array}{l}\text { St. Cruz6 } \\
1951-65\end{array}$ & $\begin{array}{l}\text { Monthly } \\
\text { Avg }\end{array}$ \\
\hline Jan. & 0.5 & 6.5 & 0.6 & 4.0 & 2.2 & 2.7 \\
Feb. & 0.3 & 16.9 & 0.1 & 6.6 & 3.8 & 5.5 \\
Mar. & 7.6 & 2.6 & 1.6 & 1.1 & 0.8 & 2.7 \\
Apr. & 24.6 & 37.0 & 16.1 & 52.2 & 12.6 & 28.5 \\
May & 111.6 & 208.9 & 226.3 & 268.9 & 260.7 & 215.3 \\
Jun. & 322.0 & 294.6 & 282.1 & 324.1 & 321.1 & 308.8 \\
Jul. & 167.2 & 166.1 & 205.2 & 345.2 & 247.3 & 226.2 \\
Aug. & 128.2 & 193.5 & 150.9 & 305.6 & 177.7 & 191.2 \\
Sept. & 293.3 & 328.1 & 356.3 & 344.0 & 361.5 & 336.6 \\
Oct. & 237.4 & 365.6 & 326.2 & 462.1 & 422.6 & 362.8 \\
Nov. & 107.4 & 80.6 & 89.5 & 171.1 & 98.7 & 109.4 \\
Dec. & 5.5 & 7.4 & 4.3 & 24.5 & 21.9 & 12.7
\end{tabular}

Total $1,405.6 \quad 1,707.8$

$1,659.2 \quad 2,309.4 \quad 1,930.9$

$1,802.6$

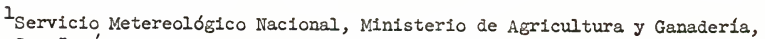
San José.

'Guanacaste $10^{\circ} 25^{\prime} \mathrm{N} 85^{\circ} 07^{\prime} \mathrm{W}$, altitude $95 \mathrm{~m}$. 3La Pacífica, Gte. $10^{\circ} 28^{\prime}$ N $85^{\circ} 09^{\prime} \mathrm{W}$, altitude $45 \mathrm{~m}$.

${ }^{4}$ Guanacaste $10^{\circ} 37^{\prime} \mathrm{N} 85^{\circ} 26^{\prime} \mathrm{W}$, altitude $144 \mathrm{~m}$.

5 Puntarenas $9^{\circ} 59^{\prime} \mathrm{N} 84040^{\prime} \mathrm{W}$, altitude $225 \mathrm{~m}$. $6_{\text {Guanacaste }} 10^{\circ} 16^{\prime} \mathrm{N} 85^{\circ} 37^{\prime} \mathrm{W}$, altitude $50 \mathrm{~m}$. 
Table 2.- Extreme temperatures, relative humidity and sunshine hours for Canas, I.P., 1 Costa Rica, C. A. ${ }^{2}$

Extreme temperatures Relative humidity Daily sunshine hours

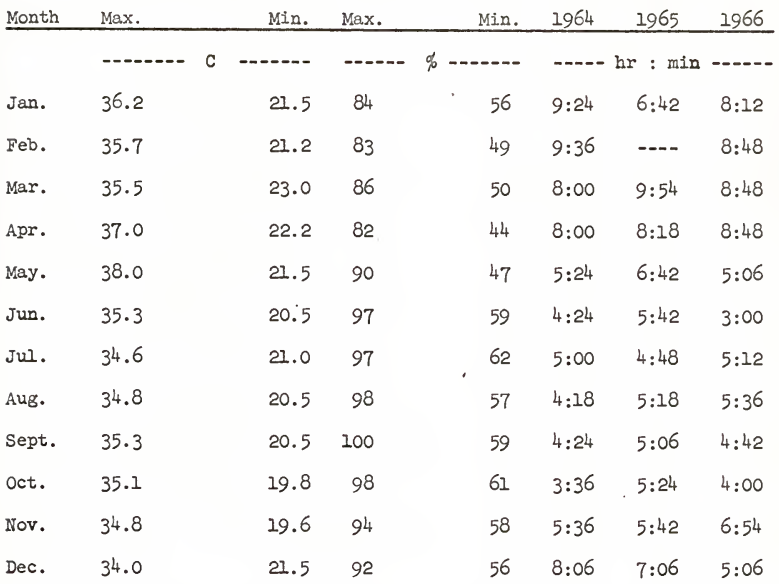

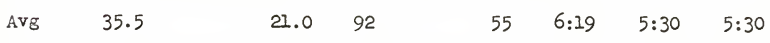

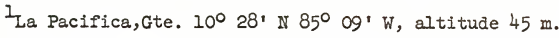

${ }^{2}$ Servicio Meteorologico Nacional, Ministerio de Agricultura y Ganaderia, San Jose. 
according to Roseveare (99). However, the Cuban savannas should not be included in this group because of the temperature influence due to large cold fronts which occasionally come from the north during the dry season.

\section{Geolosy}

The geology of this region has been described in general by the U. S. Army.3 The Nicoya complex forms the basement or oldest rocks in the region. They consist of complexly folded, faulted and partially metamorphosed sedimentary and igneous rocks, assigned to late Jurassic or Early Cretaceous time and are made of pillow basalts, basalt agflomerates, graywackes, cherts and limestones intruded by diabases and gabbros. There is a series of sedimentary rocks of Upper Cretaceous, Paleocene, Eocene, Oligocene, Miocene and Pliocene ages above the Nicoya Complex.

Intense volcanic activity has taken place during the late Miocene and Pliocene, extending into recent times in the eastern part of the country, and has spread volcanic material over the region.

The rocks of the mainland are primarily rhyolitic and andesitic tuff, containing interlayers of lava flow ranging from rhyolite to basalt. The origin of the solls of the Tempisque Valley are alluvial deposits derived largely from desintegration of volcanic ash of tuff. The rocks of the Nicoya Peninsula consist of complexly folded, faulted and altered sedimentary volcanic rocks with intruded dikes and sills of diabase and gabbro.

\section{Soils}

The solls of the region have not been studied in detail. Only general reconnaissance reports, and preliminary soil and classification 
studies are available for areas showing potential for agricultural development.

A preliminary soil and land classification map was made in 1955 in connection with an irrigation project for the Tempisque valley. ${ }^{4} \mathrm{~A}$ general reconnaissance report was also made on the soils of the region between latitude $9^{\circ} 57^{\prime}$ and $10^{\circ} 06^{\prime} \mathrm{N}$ and longitude $84^{\circ} 42^{\prime}$ and $84^{\circ} 58^{\prime}$ $W$, in the Puntarenas Province (32). This report published in 1958 described the Chomes, El Palmar, Barranca, Los Negros and Aranjuez series, covering an area of 23,860 ha. These series are characterized in general by young sandy loam to clay loam alluvial soils which are slightly acid to neutral in $\mathrm{pH}(6.6$ to 7.3$)$. They have flat topography and poor internal drainage caused by high water tables, except for the Aranjuez series which is characterized by shallow, old, residual soils which have a stony phase on hills with slopes greater than $3 \%$. The soils of this series are reddish clay loam to sandy loam, slightly acid to neutral in pH (6.2 to 6.8) and good internal drainage. All soils described in this report are low in soluble elements such as nitrogen, phosphorus and potassium. Another brief report on the soils of the Nicoya Peninsula was prepared in 1965 by the Costa Rican Ministry of Agriculture. It describes the general characteristics of some soil profiles but no detail is given in the description or location of soil units. The lack of soil data has probably affected the development of agricultural programs in this region.

\section{Vegetation and Agriculture}

The vegetation of the Pacific "Tierra Caliente" of Costa Rica was

\footnotetext{
${ }^{4}$ Costa Rica. 1955. Tempisque Valley project investigation. U. S. D. I., Bur. of Reclamation; Costa Rican MAI and STICA. 16 p.
} 
described by Standley (110) in 1937. He concluded that rainfall was the principal factor differentiating the vegetation of this region. He also mentioned that the vegetation could be described as xerophytic consisting of either forest or thickets of more or less deciduous trees and shrubs rather widely spaced. In large areas no shrubs or trees exist, or only scattered ones, and the land is a grassy savanna. The vegetation of this region is characterized by a high number of species of Leguminosae, as is usually the case in tropical regions with periods of limited rainfall. The principal large trees are represented by Enterolobium spp. (Guanacaste), Hura spp. (sand box trees), Anacardium excelsum, Sweetenia, various genera of Lauraceae, several Sapotaceae, Cassia grandis, Ceiba, Bombax, Terminalia and Cedrela. Smaller trees includes Dipterodendron, several species of Coccoloba, Tabebuia Chrysantha, Anona purpurea, Anacardium occidentalis Psidium guayaba, Simaruba glauca, Trema micrantha, and Bursera simaruba. Many of the shrubs found in this region, such as Hamelia patens and species of Casearia and Gonania, Cassia spp., Acacia farnesiana, Psidium guineense and various Anonaceae, are restricted to the Pacific coast of Costa Rica. One outstanding feature of the vegetation of the region is the presence of coyol palm, Acrocomia vinifera, and several genera of palm, such as Bactris, Desmoncus, Pyrenoglyphis and Scheelea, which are characteristic of the vegetation of the hot savannas of Latin America. Another outstanding feature of the vegetation is Cereus aragoni, the only tree cactus found in costa Rica. Few epihytes, principally Tillandsia; few orchids, such as Cattleya skinneri (guaria morada), Laelia and Epidendmu; and woody vines such as Vitis titrifolia, Cissus spp. and Combretum, also grow in this region in association with trees 
and shrubs. The grasses are represented by several species of Andropogon, Arist1da, Axonopus, Bouteloua, Eragostis, Byparrhenia, Imperata, Panicum, Paspalum, Sporobolus, etc. They grow in these savannas forming a dense sward in association with a large number of Cyperaceae and Leguminosae, such as species of Centrosema, Crotalaria, Stylosanthes, Desmodium, Indigofera, etc. Standley (110) concluded that the savanna flora of costa Rica was essentially South American, not only in genera but often in species having affinities with savannas in Panama, Venezuela and Colombia. Roseveare (99) reported in 1948 that the natural grasslands of the Pacific lowlands of Costa Rica were normally of two types, tall grasses such as Panicum maximum, Hyparrhenia mufa and Panicum purpurascens, and short grasses such as Paspalum notatum. He also indicated that jaraguagrass was a native grass to this region, which is not the case. He estimated the carrying capacity of the native range at 4.05 to 8.1 ha per mature animal. The cattle raised in the Guanacaste region represented over $40 \%$ of the total number of cattle in the country, although floods, droughts, pests and animal disease presented disadvantages which are absent in other regions in the country. The economy of the region is almost entirely agrarian and consists of cattle and annual crops which are affected by seasonal fluctuations of rainfall. It is the most important beef producing area in the country and provides approximately $36 \%$ of the cattle according to the latest agricultural census conducted in the country. 5 The areas planted to cotton represent $92 \%$ of the total area planted in the country, rice $48 \%$, corn $28 \%$, beans $26 \%$ and sugar cane $19 \%$. In

5osta Rica. 1965. Censo agropecuario 1963. Direccion General de Estadistica y Censos. Ministerio de Economia y Hacienda, San Jose. $308 \mathrm{p}$. 
addition, $49 \%$ of the exploited forest areas is present in the Guanacaste Province. However, the U. S. Army $^{3}$ reported that the extensive cutting and burning which is used to cultivate the land either with annual crops or improved grasses, have resulted in the destruction of the forest resources and caused severe erosion of the land. It is significant to note $e^{5}$ that only $6 \%$ of the number of farms surveyed in this region were using fertilizer at that time. A total of 10,773 farms were surveyed which covered 772,074 ha of agricultural land. 


\section{EXPERIMENTAL PROCEDURES}

\section{Selection of Site}

The fleld experiments were conducted at the Enrique Jimenez Nuñez Agricultural Experimental Station, Guanacaste Province, Costa Rica. The station is located at latitude $10^{\circ} 21^{\prime} \mathrm{N}$ and longltude $85^{\circ} \mathrm{O} \mathrm{9}^{\prime} \mathrm{W}$, near Taboga in the Tempisque Valley, in the hot climate savanna in the Pacific lowlands of the country.

A three-year-old sward of Jaraguagrass that had not been grazed or fertilized was selected to lay out the experiment. The topography is flat and the surface soil is primarily clay. Weed contamination was not sufficient to affect the purity of the grass stand.

\section{Methods}

\section{Fleld experiments}

A split-plot experiment consisting of three replications, three nitrogen treatments in the main plot and eight growth periods during the dry season, was established on October 13, 1965. The sward was cut by machete and the trash removed from the field prior to f'ertilization. The fertilization consisted of an equivalent of 0,75 , and $150 \mathrm{~kg}$ nitrogen per ha in the form of ammonium nitrate. In addition to it, an equivalent of $37.5 \mathrm{~kg}$ phosphorus per ha in the form of concentrated superphosphate was applied uniformly to the plots. The nitrogen treatments were identified as $N_{0}, N_{1}$, and $N_{2}$ corresponding to 0,75 , and $150 \mathrm{~kg}$ nitrogen per ha, 
respectively. The subplots were harvested at 48, 62, 84, 92, 105, 115, 128, and 143 days of growth into the dry season after fertilization, corresponding to the following harvest dates: November 30, December 14, January 5, 13 and 26, February 9 and 18, and March 5, 1965-66, respectively. Strips of $3.5 \mathrm{~m}^{2}$ were harvested with a sickle bar mower at a height of $5 \mathrm{~cm}$. All the green forage from the harvested area was welghed and two samples were collected from each plot to determine dry matter production and for chemical analysis. The roots, in the top $20 \mathrm{~cm}$ of soil from an area of $0.25 \mathrm{~m}^{2}$, were sampled inmediately after the forage was harvested on each harvest date. The roots were screened successively with 2 and $1 \mathrm{~mm}$ sieves and washed twice with tap water to remove impurities.

The harvested plots were allowed to regrow without further fertilization upon arrival of the rainy season at the beginning of May. The regrowth was harvested on August 19, 1966 to determine dry matter production and for chemical analysis to evaluate residual effects of the dry season and fertilizer applied at the beginning of the experiment. The harvest and sampling were conducted in a similar way for both the day and rainy seasons.

All the plant material, forage and roots, was oven-dried, ground in a Wiley Mill to pass a 350-micron screen before being shipped to the University of Florida for chemical analysis.

\section{Soil characterization}

The soils of the experimental site were characterized the first part of December, just prior to the beginning of the dry season. Two pits were dug to a depth of $130 \mathrm{~cm}$ and field observations on horizon distribution, soil color, structure and consistency were made. At the 
same time, clods were collected from the different horizons for bulk density measurements. Additional samples were obtained with a knife from the different horizons; they were air-dried, passed through a 2.0 m sieve, placed in double paper bags and shipped to the University of Florida for physical and chemical analysis.

Physical Analysis

The soil samples collected in the field were analyzed in the laboratory for particle density, bulk density, total porosity, particle size distribution and the following moisture characteristics: moisture equivalent, wllting coefficient and permanent wilting point. Determination of particle density, bulk density and permanent wilting point were conducted at the Soil Analysis Laboratory, Ministry of Agriculture, San Jose, Costa Rica.

Particle density was determined using a pycnometer according to the standard method by Blake (8).

Bulk density was determined on clods following the method described by Blake (8).

Total porosity was calculated using the ratio of bulk density to particle density of the soil and substracting from unity. Percentage pore space was obtained by multiplying by 100 according to the procedure given by vomocil (124).

Particle size distribution was determined on a 50-g sample by the standard Bouyoucos method (12) with Calgon as a dispersing agent, but with twice the concentration recomended to assure dispersion. 
Moisture equivalent approximates field capacity of fine textured soils and was determined by the standard method of centrifugation intro- duced by Briggs and McLane (18). Wilting coefficient approximates the permanent wilting point of fine textured soils and was calculated by dividing the values for moisture equivalent by the constant factor 1.84 according to calculations by Briggs and Shantz (19). Permanent wilting point was also determined by the use of the pressure membrane at a suction of $15.4 \mathrm{~kg}$ per $\mathrm{cm}^{2}$ (15 atm) according to the method developed by Richards (98).

\section{Chemical Analysis}

Duplicate soil samples were taken to determine moisture content and the results of analysis were calculated on an oven-dry weight basis (105 C). The grass samples were dried at $70 \mathrm{C}$, and the results calculated on that oven-dry weight basis.

Duplicate ground root samples of $1 \mathrm{~g}$ each were ashed at $650 \mathrm{C}$ for $1 \mathrm{hr}$ in the muffle furnace to determine impurities remaining after washing with $0.1 \mathrm{~N}$ hydrochloric acid. The results of analysis were calculated on an oven-dry weight basis $(70 \mathrm{C})$, free of impurities, primarily soil.

The soil $\mathrm{pH}$ was determined in a 2:1 water to soil suspension after $12 \mathrm{hr}$ with a thin-glass electrode and a Corning $\mathrm{pH}$ meter Model 7 . Enough solid potassium chloride was added to the suspension in water to make a 1 N salt solution. The $\mathrm{pH}$ was determined again after $30 \mathrm{~min}$.

Organic carbon in the soil was determined by the Walkley-Black wet combustion method as modified by Walkley (126). The factor 1.724 was used to convert organic carbon to organic matter. 
Total nitrogen in soil as well as in plant material was determined by a modified micro-Kjeldahl method described by Volk-Fontein 6 . Crude protein in the forage was calculated by multiplying nitrogen concentrations by the factor 6.25 .

Total elementary phosphorus in soil was extracted by perchloric acid digestion and determined colorimetrically by the vanadomolybdophosphoric yellow color method described by Jackson (60). Soluble phosphorus was extracted from the soil with hydrofluoric-hydrochloric acid solution by the Bray and Kurtz method (14) and determined colorimetrically by the molybdenum blue method of Fiske and Subbarow (42).

Cation exchange capacity was determined by the method of ammonium saturation described by Chapman (29). The adsorbed ammonium was determined by the acid-sodium chloride method also described by Chapman (29). Exchangeable cations were determined by extracting $10 \mathrm{~g}$ of soll with I I ammonium acetate according to the method of Peech et al. (91). The solution extracted was evaporated to dryness, the organic matter was oxidized with $6 \underline{\mathrm{N}}$ nitric acid solution and $30 \%$ hydrogen peroxide, and evaporated to dryness. The salts were taken up and diluted to $100 \mathrm{ml}$ with 0.1 N hydrochloric acid solution.

Total cations in soil were determined on a 1-8 sample by decomposition with hydrofluoric acid according to the method by Jackson (60). The solution was taken up and diluted to $100 \mathrm{ml}$ with distilled deionized water.

6 Unpublished mimeographed sheet. Department of Soils, University of Florida, Gainesville, Fla. 
Duplicate l-g plant samples were dry ashed in a muffile furnace at $450 \mathrm{C}$ for one hour for phosphorus and potassium, and at $550 \mathrm{C}$ for $\mathrm{l} \mathrm{hr}$ for calcium and magnesium. The salts were dissolved again in hydrochloric acid and diluted to a volume of $100 \mathrm{ml} 0.1 \mathrm{~N}$ acid solution.

Determination of phosphorus in the plant material was made colorimetrically by the molybdenum blue method of Fiske and Subbarow (42).

Determination of potassium in the soil extracts and plant material was made with a Beclman DU Flame Spectrophotometer with hydrogen-oxygen burner assembly at $768 \mathrm{mu}$. Sodium was also determined with the same flame spectrophotometer but at $589 \mathrm{mu}$ wave-length. Calcium was determined complexometrically by the versene titration method modified by Diehl (37); and magnesium was determined colorimetrically by the method of Carver and Robertson (28).

\section{Forage Cellulose Digestion}

Two-gram duplicate forage samples corresponding to the treatments of $150 \mathrm{~kg}$ nitrogen per ha at 48 days of growth and 0 nitrogen at 143 days of growth, respectively, were fermented for, 6, 12, 18, 24, 36, 48 and 72 $\mathrm{hr}$ with rumen liquid in an all-glass system according to the method described by Quicke et al. (94). The source of rumen Iiquid was a threeyear-old fistulated steer fed with a constant diet consisting of bermudagrass hay and soybean meal. Cellulose content in the samples was analyzed before and after fermentation by the method of Crampton and Maynard (33). The in vitro cellulose digested was expressed as the percent cellulose that was dissolved after fermentation, on the ary-weight basis $(70 \mathrm{C})$. This experiment was conducted with samples from two different dates 
to establish the fermentation pattern for the jaraguagrass. Then, duplicate forage samples corresponding to all the nitrogen treatments at 48,92 , and 143 days of growth, respectively, were compared for cellulose content and cellulose digestion using the same system and methods already described and for a fermentation period of $36 \mathrm{hr}$. This experiment was conducted on three different dates and the results expressed on the dry weight basis $(70 \mathrm{C})$.

\section{Statistical Analysis}

The results from the field experiment and the forage cellulose digestibility were analyzed statistically by the method described by Snedecor (108). 


\section{RESULTS AIN DISCUSSION}

\section{Soil Characterization}

Profile description, and physical and chemical soil properties of the experimental site are given in Appendix Tables 13, 14 and 15, respectively. A soil sample from El Capulin, former Agricultural Experimental Station in Liberia, Guanacaste Province, Costa Rica, has been included in the last two tables for comparisons of the results of field experiments conducted by Andrade et al. (2) and those reported in this investigation. The morphological characteristics of this soil fall into the category of the Order Vertisol according to the Soil Survey Staff (109). Similar soils have been included by Dudal (39) under the general name of dark clay solls of tropical and subtropical regions. The physical properties of this soil seem to be adequate for field crops and pastures production, except possibly the total porosity and high clay content may present management problems, especially during the rainy season. The native fertility of this soll seems to be relatively low as indicated by its chemical properties. The total nitrogen, and the total and soluble phosphorus are relatively low, even though the organic matter content and $\mathrm{pH}$ seem to be adequate. The total cations and exchangeable bases were relatively high but there was an imbalance between some of the elements analyzed. The total and exchangeable calcium and magnesium seem to be in adequate amounts and proportions to support good plant growth, but the total and exchangeable potassium seem to be very low as compared to 
the other bases, including sodium. Nitrogen and phosphorus are probably the two most deficient elements in the soil and probably affect pasture production at the present time.

\section{Field Experiment During the Dry Season}

\section{Dry matter}

The effect of nitrogen fertilization on the yields of oven-dry jaraguagrass forage produced during the dry season is shown in Table 3 . The forage dry matter production increased to more than 6,000 kg per ha to the middle of the dry season with application of nitrogen, and decreased after the seeding period when the plants in the field began to dry and deteriorate. This nitrogen effect was highly significant (1\% level, Appendix Table 16). There were no significant differences between the $N_{1}$ and $N_{2}$ treatments and no interaction between the nitrogen treatments and the days of growth. At the same time, the dry matter production of the roots and crowns followed more or less the same pattern as the forage shoots, Table 4, but difficulties in sampling prevented statistical analysis of these results.

These results are similar to those presented by Andrade et al. (2) for the same region in Costa Rica; however, root data were not obtalned in their study.

Troughton (117) summarized data for root weights produced by swards in different climatic regions, including the tropics, and under different conditions of sward age, management and depth of sampling. In general, the results reported in this investigation corresponded to the average figures reported by different investigators for tropical, as well as temperate species of grasses. 


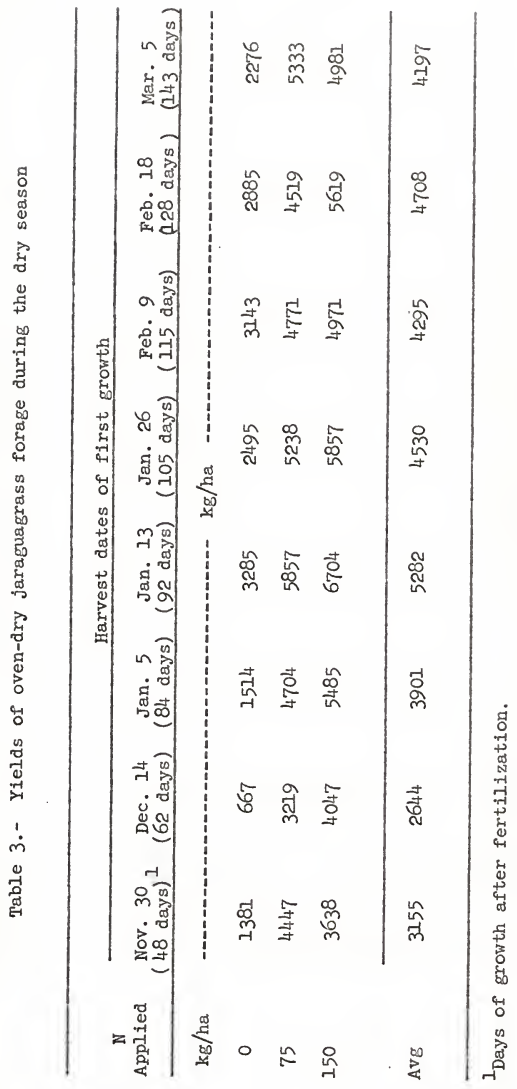




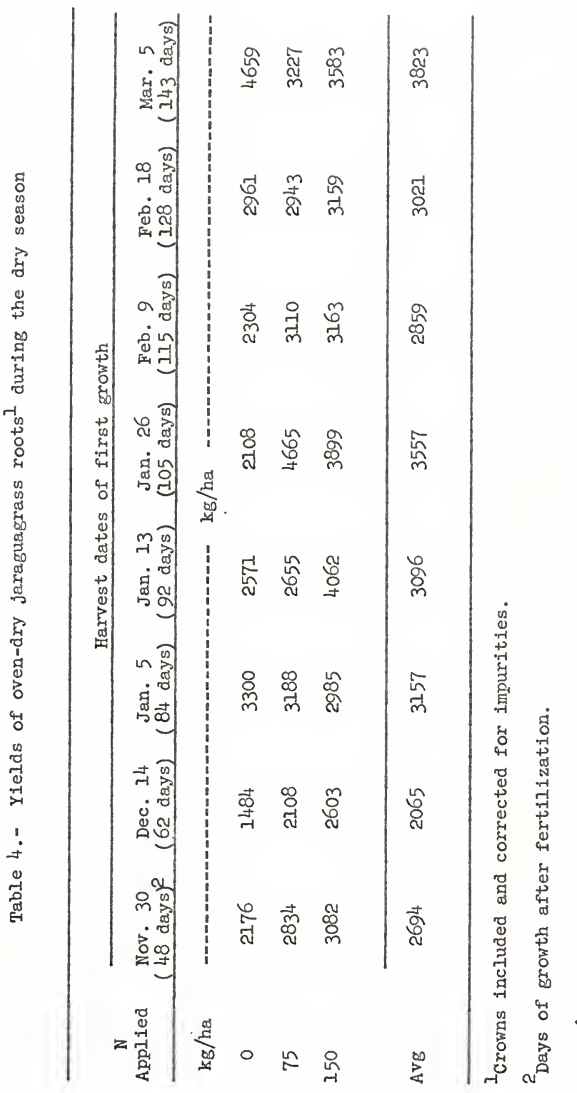




\section{Nitrogen}

The effects of nitrogen fertilization and days of growth on forage nitrogen concentrations and total nitrogen contents during the dry season are shown in Flg. 2 and 3 and Appendix Tables 17 and 18 . The nitrogen concentrations as well as the total nitrogen contents of the forage increased with nitrogen fertilization to more than $1.00 \%$ and $40 \mathrm{~kg}$ nitrogen per ha at 48 days of growth. However, there were interactions of nitrogen fertilization with days of growth on both nitrogen concentrations and contents (Appendix Tables 19 and 20) which nullified any nitrogen effect after 84 days of growth. These figures also show that the decrease in nitrogen concentrations was not entirely due to dilution from the increased dry matter production during the first part of the dry season, and that a substantial amount of nitrogen was actually lost from the forage shoots. The nitrogen concentrations and the total nitrogen contents of the roots and crowns increased with the nitrogen treatments (Appendix Tables 21 and 22) and tended to increase as the plant matured, as indicated by the days of growth into the dry season. These results were not analyzed statistically due to difficulties in sampling. However, there was a correlation between the total nitrogen content of the shoots and the total nitrogen content of the roots in the volume of soil sampled for each nitrogen fertilizer treatment. Fig. 4 shows that the total nitrogen contents of the forage shoots decreased as the total nitrogen contents of the roots increased during the dry season. The correlation coefficients for both nitrogen fertilizer treatments were significant at the $10 \%$ level and there was no correlation for the control treatment. The increase in total nitrogen contents of the roots could have been associated with the possibility of continuous nitrogen uptake from the 


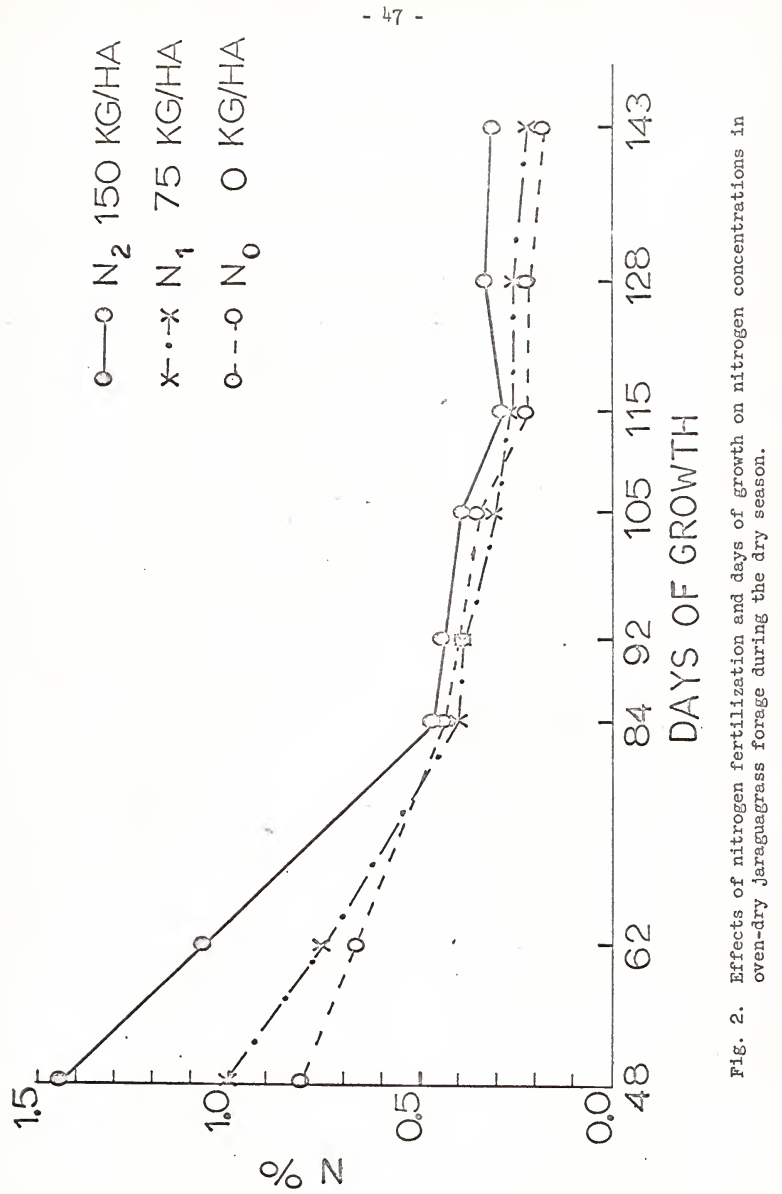




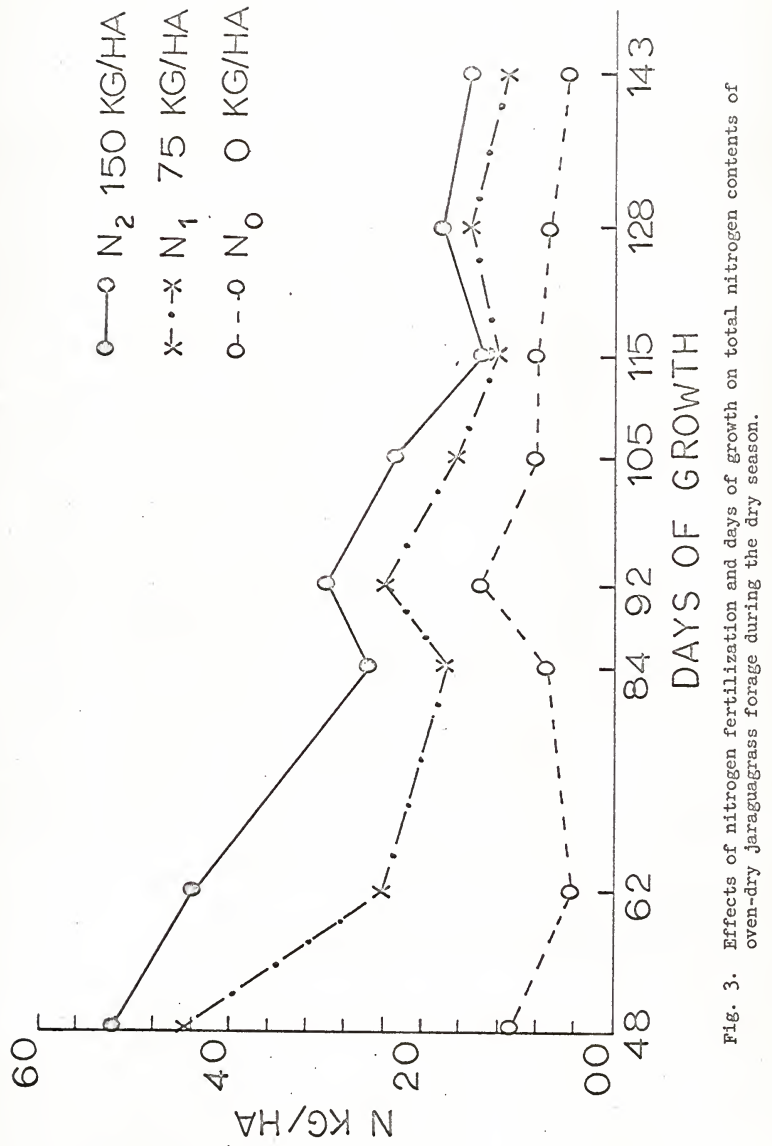




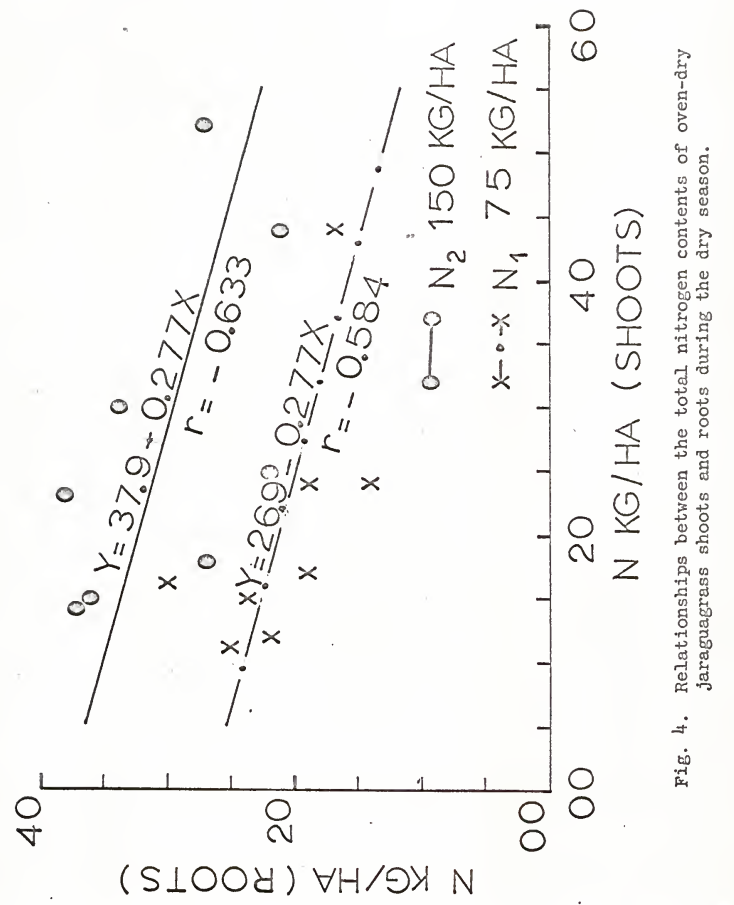


fertilizer nitrogen even though the soil was dried, as was indicated by Volk (123), working with corn. However, it is significant that this possible nitrogen absorption did not result in an increase in the total nitrogen contents of the forage; on the contrary, the increase in total nitrogen contents of the roots occurred at the same time that the total nitrogen contents of the shoots decreased. These results do not eliminate completely the possibility of nitrogen uptake by the roots from the dry soll a contributor to the increase in their total nitrogen content. Possibly this is one reason, together with the sampling error involved, for the low correlation coefficients found in this investigation. However, the total nitrogen contents of the roots during the dry season seemed to be closely assoclated with a factor or factors other than nitrogen uptake by the roots. Nitrogen translocation from the shoots could have contributed to the Increase in the total nitrogen contents of the roots during the dry season.

The results of the present investigation seem to agree with those reported by Weinmann (129). However, he later explained (131) that the translocation of nitrogen and phosphorus to the roots resulted from the formation of water soluble decomposition products which occurred at maturity in dying leaves with the initiation of low autumn temperatures. Low temperature was not a factor in the present investigation and translocation seemed to take place even before the tissues began to dry under conditions of soil moisture stress in the field. The present investigation also shows results that agree with thóse of Andrade et al. (2), even though they worked with a different soil type from El Capulin Experimental Station in Liberia with a slightly different soil moisture regime. 
The percentages of fertilizer nitrogen recovered in the forage at the different harvest dates are shown on Table 5. Nitrogen recovery was less than $45 \%$ for the $N_{1}$ treatment at 48 days of growth and decreased to less than $10 \%$ at the end of the experiment. If nitrogen recovery was the only measurement of fertilization efficiency, it was probably not economical to fertilize the grass at the end of the rainy season to increase forage quality for grazing during the dry season. However, the increase in ary matter production as the result of fertilization must also be considered.

These results are in accord with those found under similar conditions in the tropics and subtropics, according to the literature. It can be assumed that part of the nitrogen applied at the end of the rainy season was immobilized in the roots and would be translocated to the shoots with improvement in soil moisture.

Phosphorus

The effects of nitrogen fertilization and days of growth on forage phosphorus concentrations are shown in Fig. 5 and Appendix Table 23. The phosphorus concentrations were identical at the $48 \mathrm{th}$ day of growth, regardless of the nitrogen treatment. After that the concentrations decreased significantly (Appendix Table 24). Phosphorus concentrations decreased from $0.19 \%$ at the beginning to about $0.05 \%$ at the end of the experiment. The decrease was accelerated by increasing rates of nitrogen fertilization. Days of growth also had a highly significant effect on phosphorus concentrations. The interaction between nitrogen, treatments and days of growth was also highly significant, meaning that these two factors affected the forage phosphorus concentrations differentially as the dry season progressed. 


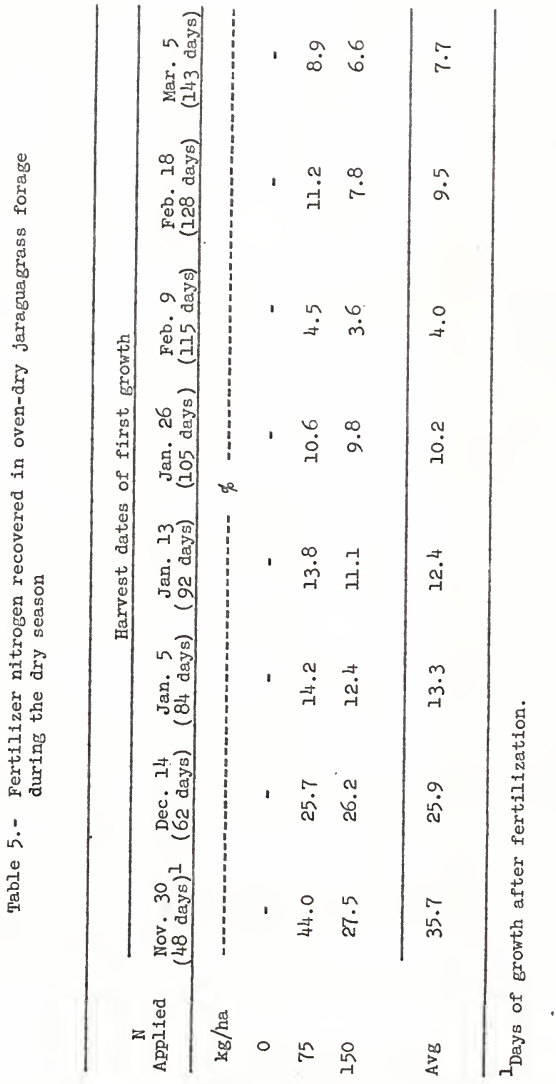




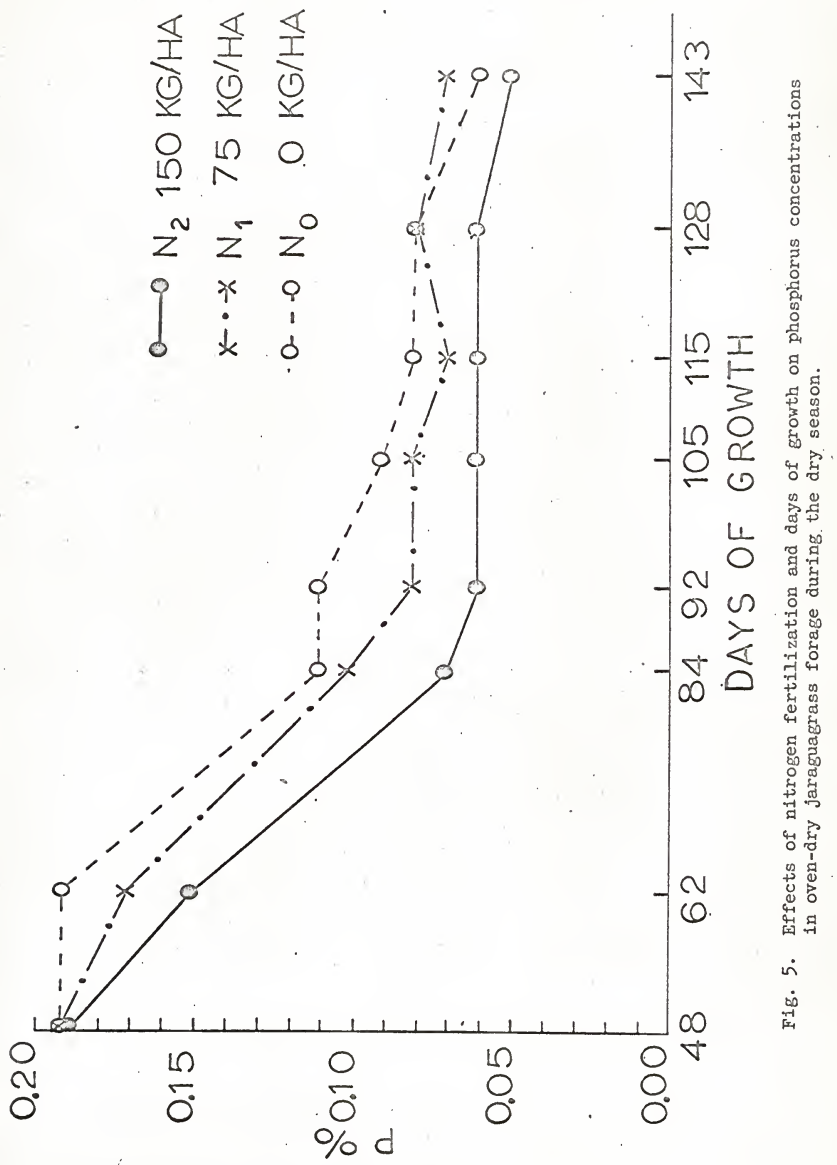


The effects of nitrogen fertilization and days of growth on total forage phosphorus contents are shown in Fig. 6 and Appendix Table 25. Total forage phosphorus increased with nitrogen fertilization mainly as the result of the increase in forage yield. Total phosphorus was $8.6 \mathrm{~kg}$ per ha at the beginning of the experiment with the $N_{1}$ treatment and decreased as the dry season progressed. The effects of nitrogen treatments and days of growth were highly significant (Appendix Table 26). There was also a highly significant interaction of these two factors. This indicated that losses of forage phosphorus were not due to dilution from the increase in dry matter as the plant grew and occurred regardless of the nitrogen fertilization.

Fig. 7 shows the relationship between forage nitrogen and phosphorus concentrations for each nitrogen treatment. There was a highly significant correlation between the concentrations of these two elements in the forage for each nitrogen treatment. There was also a highly significant correlation between the total nitrogen and total phosphomus contents of the forage for each nitrogen treatment, as shown in Fig. 8. These relationships indicated that the phosphorus was moving out of the shoots at a rate proportional to the nitrogen content of the forage at the beginning of the dry season.

Phosphorus is a very stable element in the metabolism of plants and it is improbable that it could have been volatilized from the shoots, at least in such quantities as shown in the present investigation. There was not sufficient rainfall to have leached phosphorus from the leaves and no appreciable loss of leaves occurred from the plants during the course of this investigation. These data suggest that phosphorus as well as 


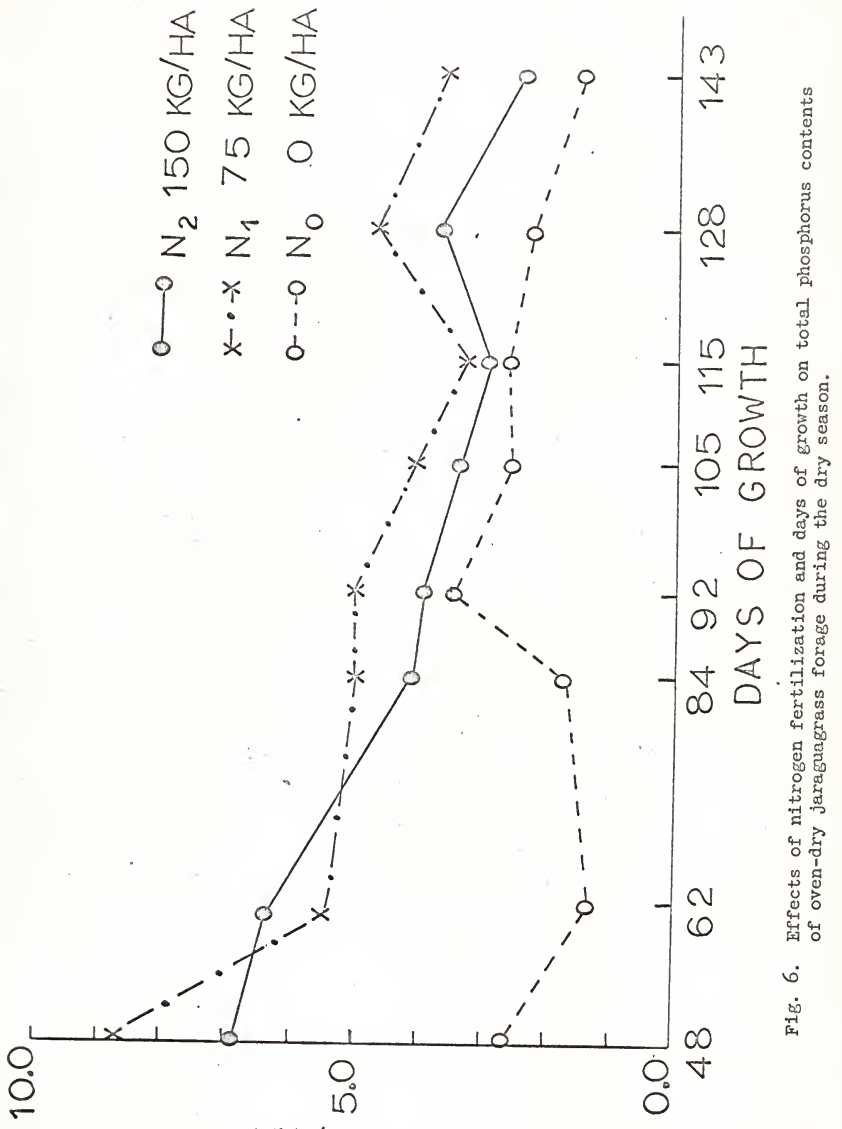

$\forall H / O Y$ d 


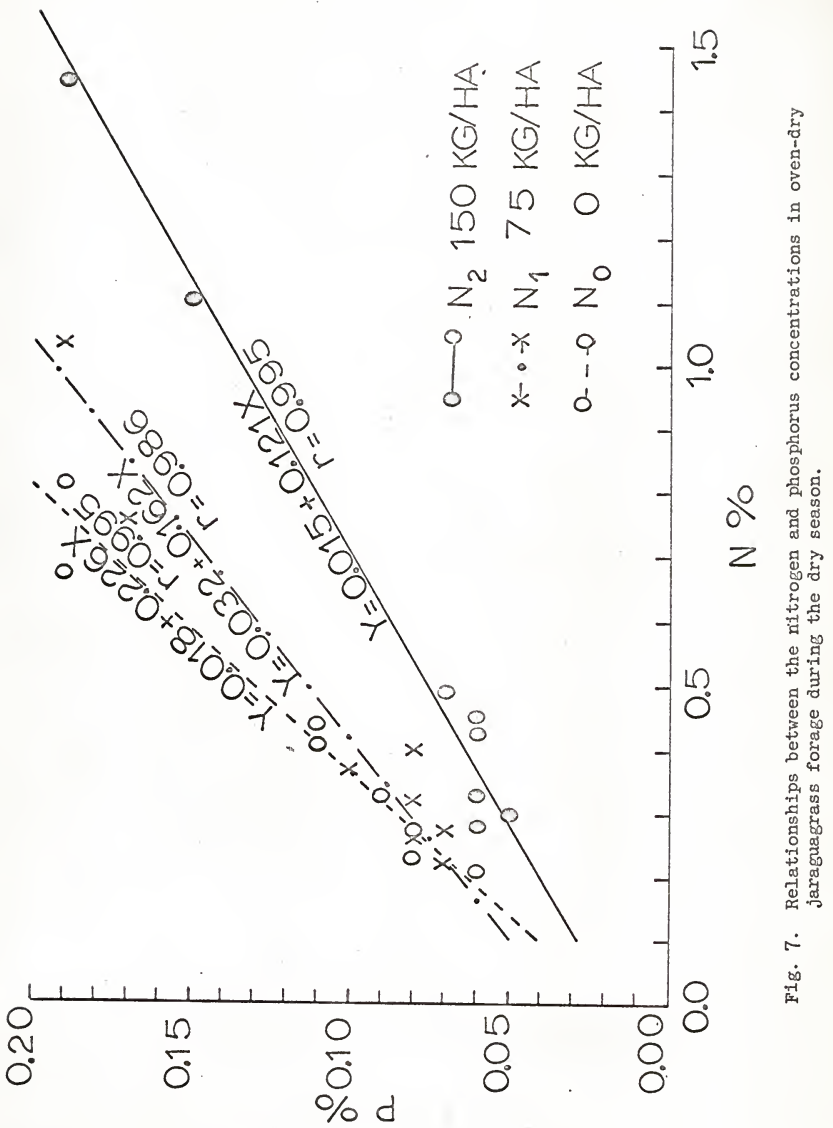




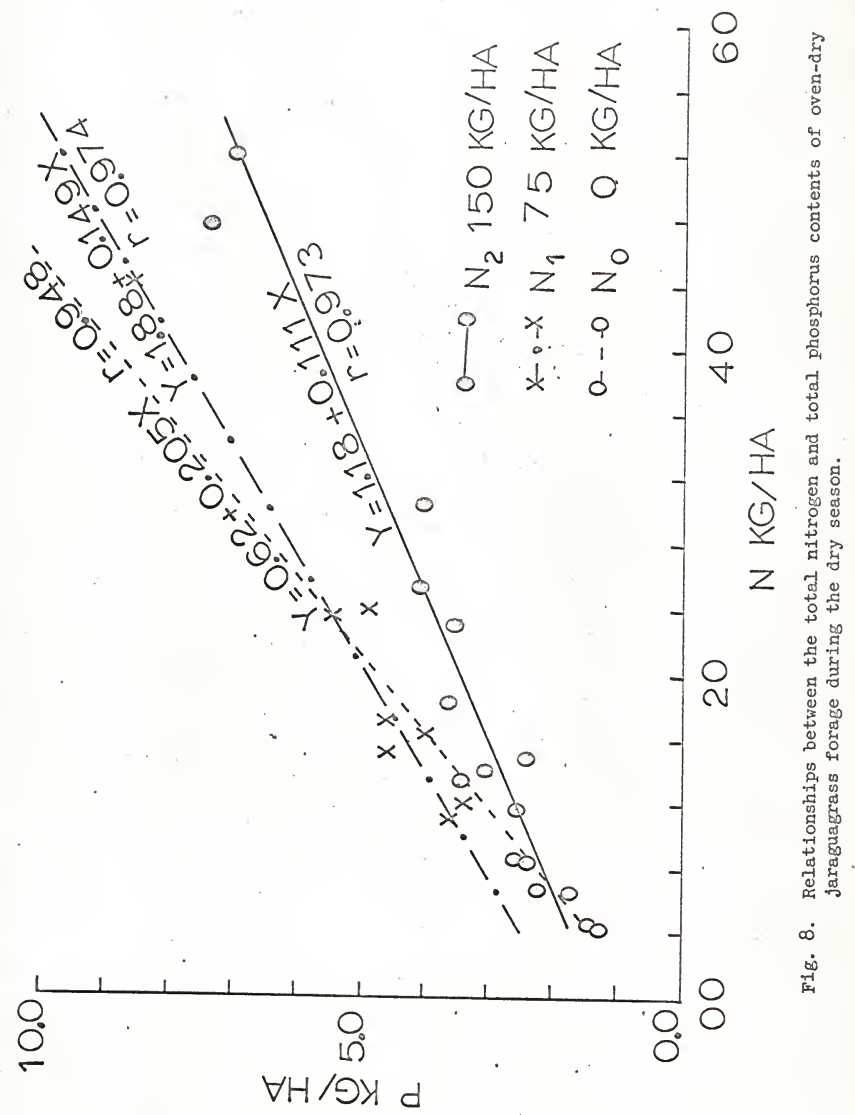


nitrogen was translocated from the shoots to the roots as the result of soil moisture stress.

Appendix Tables 27 and 28 show the phosphorus concentrations and total phosphorus contents of the roots during the dry season. There was no relationship between the phosphorus contents of the shoots and the roots of the grass in the present investigation.

\section{Field Experiment During the Rainy Season}

\section{Dry matter}

The residual effect of nitrogen fertilization on the yields of oven-dry jaraguagrass forage regrowth during the rainy season is shown in Table 6. There was no significant effect of the nitrogen treatments on the yields of forage (Appendix Table 29). This indicates no residual effect of the nitrogen applied at the beginning of experiment on plant regrowth after initial harvest. The effect of days of growth on ary matter production during the rainy season was significant at the $5 \%$ level. However, there was a highly significant interaction between the nitrogen treatments and days of growth. The effect of the nitrogen accumulated in the roots on plant regrowth is shown by the fact that the average ary matter yield for all treatments increased as the days after initial harvest decreased, as shown in Table 6. The plants harvested on November 30 accumulated less nitrogen in the roots than those harvested on March 5, as shown in Appendix Table 22. The plant regrowth started essentially at the same time with the beginning of the rainy season during the first week of May, so the difference in yields could not be attributed to difference in the days of growth at the time of sampling. The interaction between the nitrogen treatments and the days of growth 


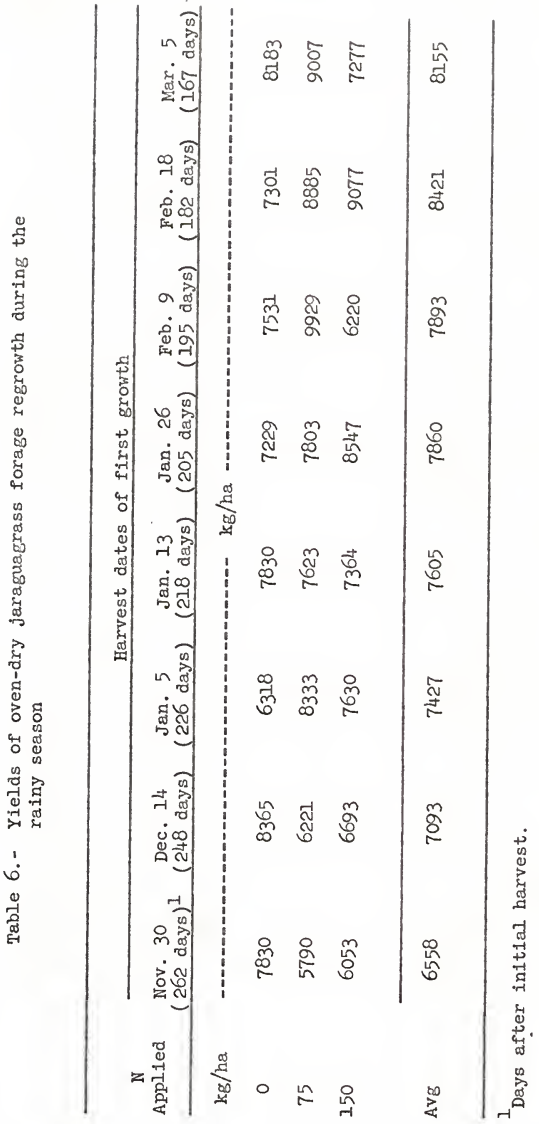


can be explained by the fact that more nitrogen had accumulated in the roots as a result of fertilization at the end of the previous rainy season and from translocation from the shoots to the roots as the dry season progressed. Therefore, the nitrogen that accumulated in the roots during the dry season had a beneficial effect on plant regrowth as soon as the soil moisture condition improved with the beginning of the rainy season. The lack of significance for nitrogen treatments suggested that the unrecovered nitrogen was held in an unavallable organic form in the soil since there was no sipnificant rainfall to cause leaching.

\section{$\underline{\text { Nitrogen }}$}

The effects of nitrogen fertilization on nitrogen concentration and total nitrogen content of the forage during the rainy season are shown in Tables 7 and 8 . There was no significant effect of the nitrogen treatments on the nitrogen concentrations or on the total nitrogen contents of the forage during the following rainy season (Appendix Tables 30 and 31). This indicated no residual effect of the nitrogen applied at the beginning of the experiment on nitrogen concentrations or total nitrogen contents of the forage during the rainy season.

Appendix Tables 30 and 31 also show that the effect of days of growth on nitrogen concentrations and total nitrogen contents of the forage during the rainy season were significant in both cases. However, the interactions between the nitrogen treatments and the days of growth on nitrogen concentrations and total nitrogen contents of the forage were significant at the $5 \%$ and $1 \%$ levels, respectively. This seemed to indicate that the nitrogen accumulated in the roots during the ary season was translocated to the shoots when the soil moisture condition improved. The interaction of nitrogen treatment with days of growth could be 


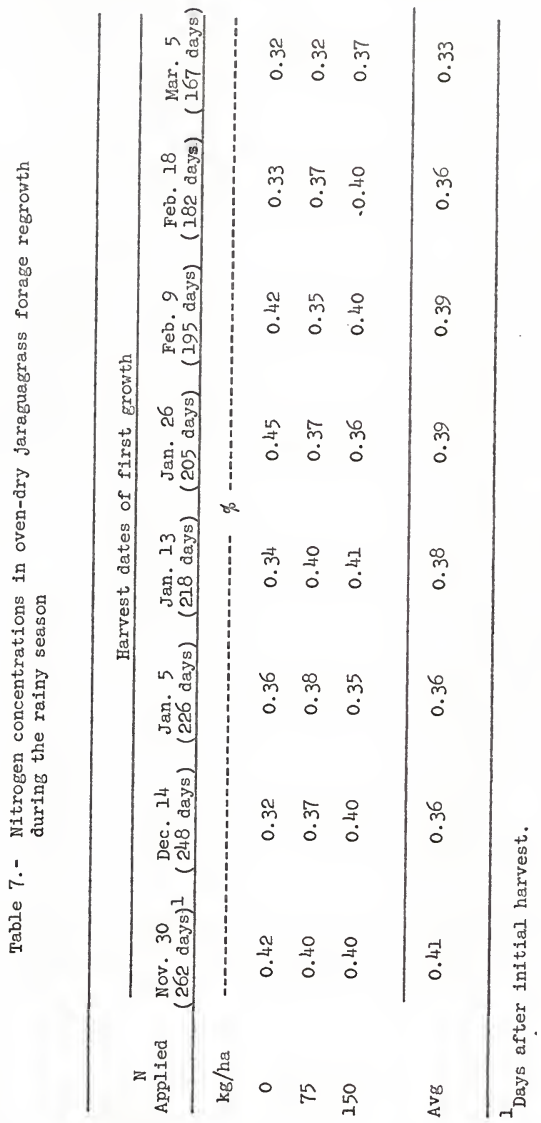




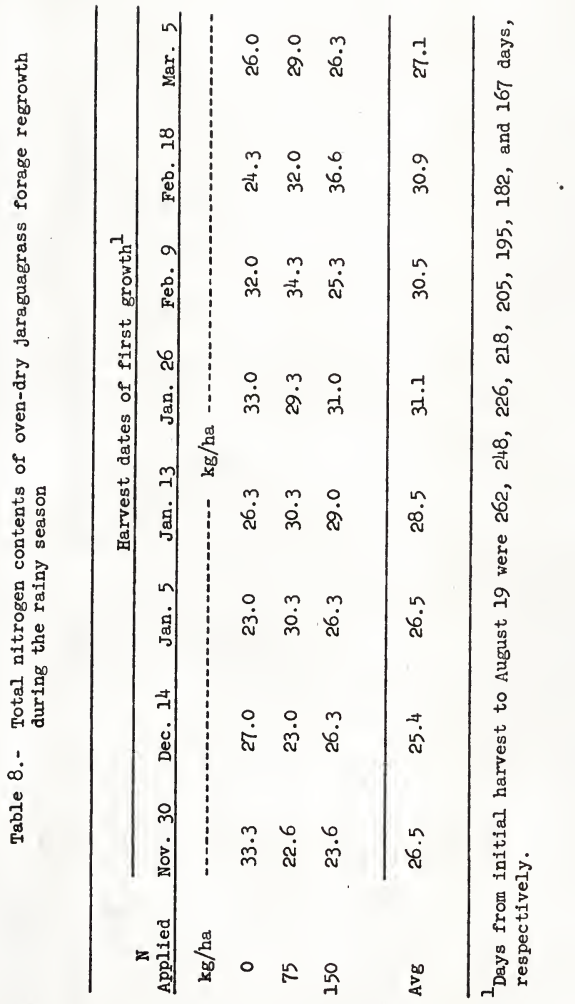


explained by the fact that more nitrogen accumulated in the roots with nitrogen fertilization.

\section{Forage Quality}

\section{Crude protein}

The crude protein concentrations and total crude protein contents of the forage increased with fertilization up to $9.00 \%$ and $327 \mathrm{~kg}$ per ha, respectively, with the $\mathbb{N}_{2}$ treatment at 48 days of growth and then declined very rapidly as the dry season progressed, Tables 9 and 10. The effect of nitrogen fertilization on the crude protein concentrations in the forage did not last beyond the third harvest date and after that it was essentially the same, regardless of the nitrogen treatment. The decline in the total crude protein of the forage during the dry season was 2.48 , 2.15 and $0.42 \mathrm{~kg}$ per ha per day corresponding to the $\mathrm{N}_{2}, \mathrm{~N}_{1}$ and $\mathrm{N}_{0}$ treatments, respectively. The total crude protein contents of the forage at the end of the dry season corresponding to the nitrogen fertilization was high compared to the check treatment because of the higher amount of dry matter produced.

The levels of crude protein in the forage were below those recommended for normal growth of beef cattle by the National Research Council (50), except possibly for the $\mathbb{N}_{2}$ treatment at the first harvest date. This indicated that the jaraguagrass forage would not be able to supply during the dry season the protein required for normal growth by beef cattle, even with high rates of nitrogen fertilization at the end of the rainy season. It is expected that cattle, grazing this type of forage as their sole source of protein, will lose weight since the crude protein 


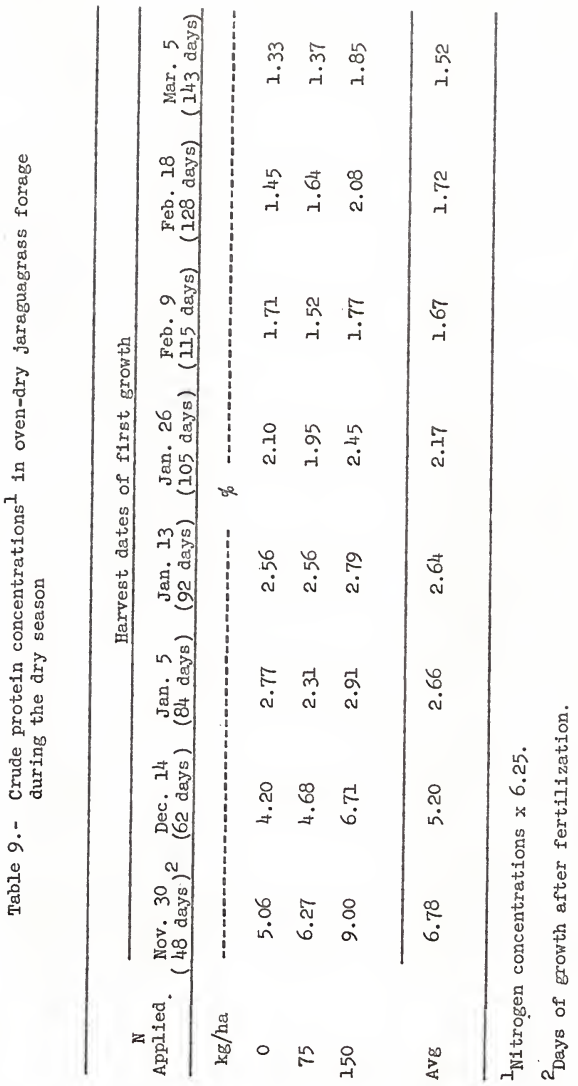




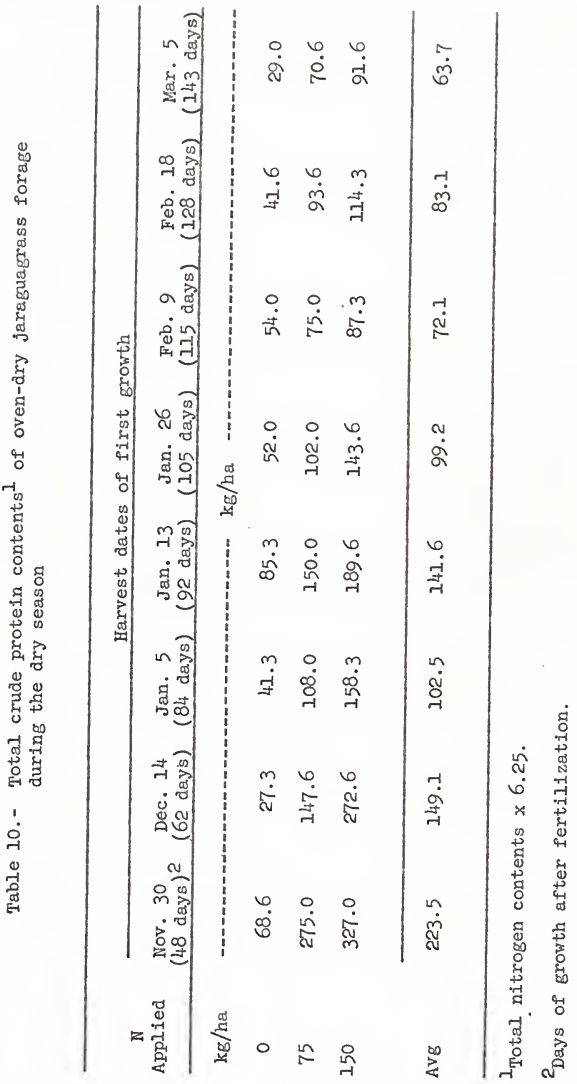


concentrations declined to less than $3 \%$ by the third harvest date. Miller et al. (80) indicated that levels of this magnitude will not provide maintenance requirements for beef cattle.

The residual effect of nitrogen fertilization on forage protein concentrations during the rainy season is shown in Table 11 . Levels of crude protein in all the treatments were below those indicated as the minimum requirement for beef cattle maintenance. A protein supplement should be used during the entire year to provide adequate levels of protein for animals grazing jaraguagrass, under conditions similar to those encountered in the present investigation.

Cellulose concentrations and in vitro cellolose digestion

Fig. 9 shows the in vitro celluzose digestion pattern for two qualities of jaraguagrass forage for different fermentation periods. The higher quality forage produced higher cellulose digestibility.

Table 12 shows the cellulose concentrations and in vitro cellulose digestion of the forage during the dry season. The nitrogen fertilization increased the cellulose concentrations in the forage and the digestion; both effects were highly significant (Appendix Tables 32 and 33). The cellulose concentrations in the forage increased as the dry season progressed, but its digestion decreased at the same time. Both effects were highly significant. There were also highly significant interactions between these two factors on cellulose concentrations in the forage and the digestion.

These data suggested that the quality of the jaraguagrass forage in terms of its cellulose concentrations, and cellulose digestion was fairly good, even at the end of the experiment during the dry season. 


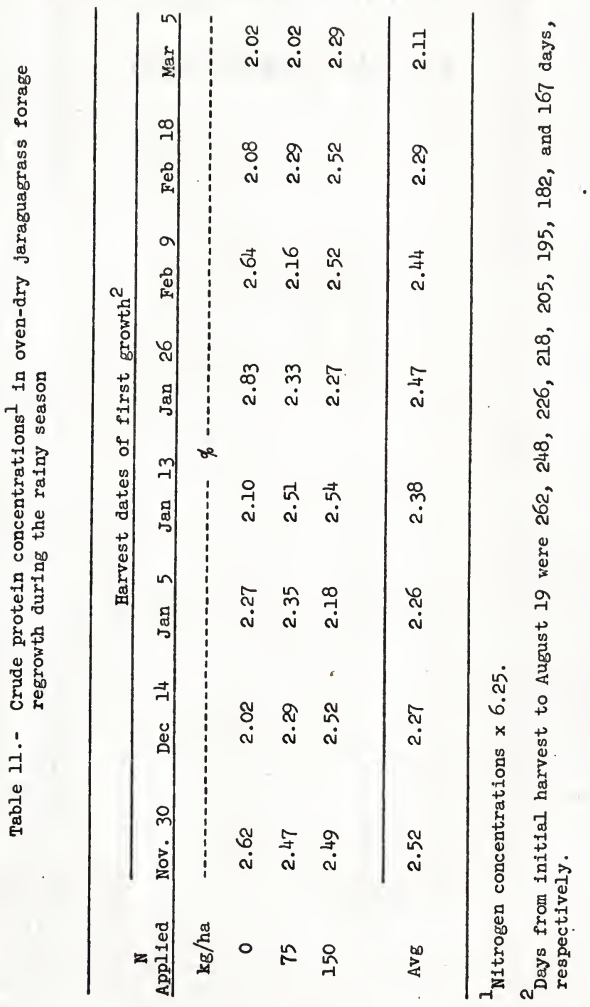




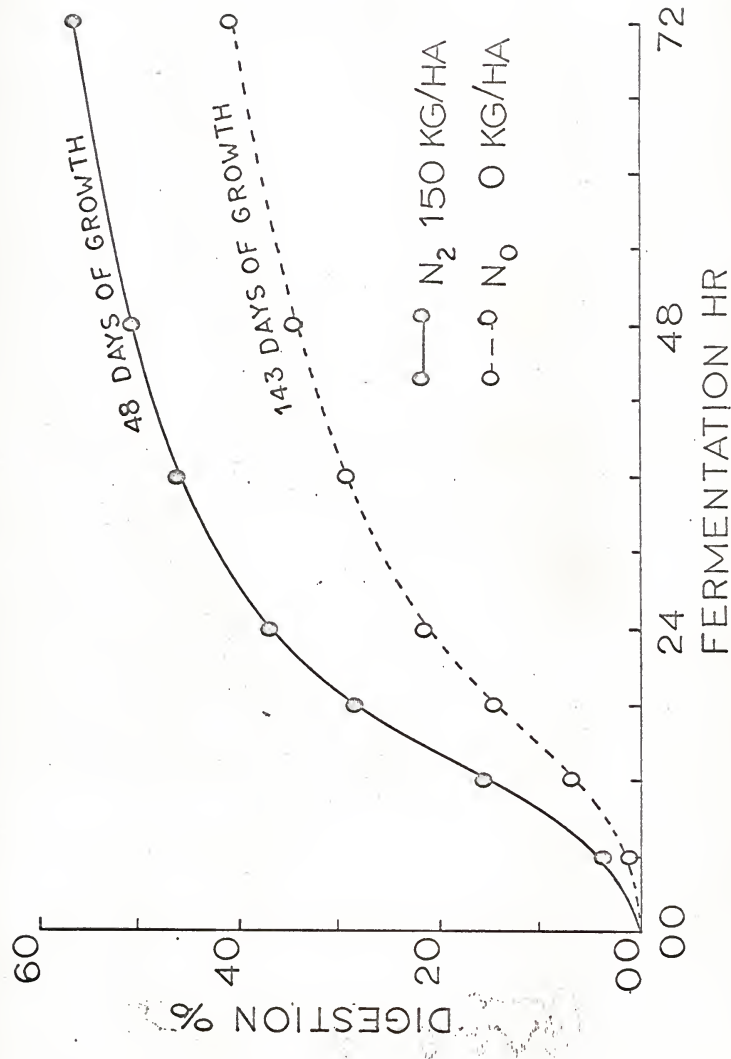

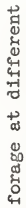

. 6

$\sum$ 氚

E

(1) 0

명 


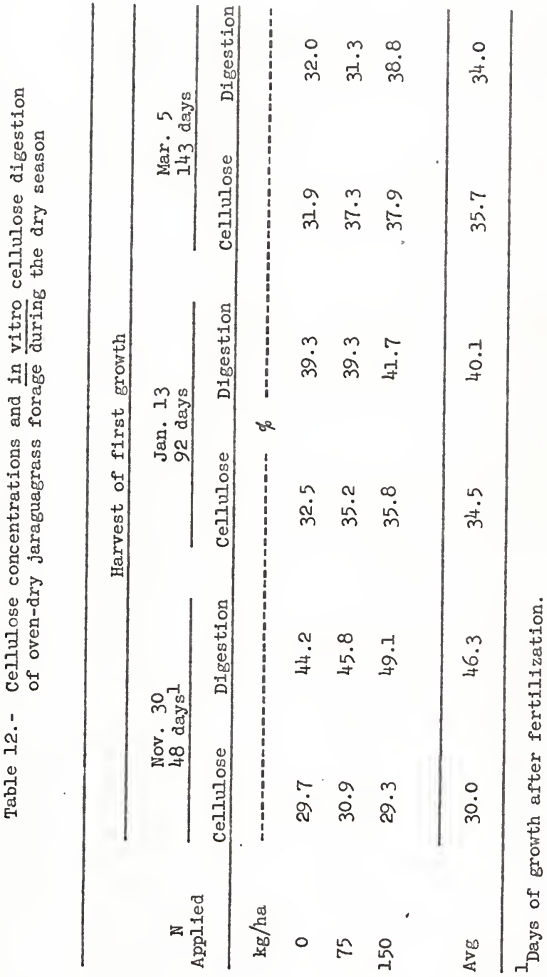


However, the foraige intake by the animals could be low due to the low crude protein concentrations at this stage of growth affecting the gross energy intake by the animals. Jaraguagrass could be used as a roughage in dry tropical conditions combined with a protein supplement and molasses to improve palatability and forage intake.

\section{Mineral composition}

Appendix Tables $23,34,35$, and 36 show the phosphorus, potassium, calcium and magnesium concentrations in the forage during the dry decreased as the dry season progressed. At the same time, the calcium concentration remained more or less constant. The concentration of these elements in the forage were more or less the same in all the plots sampled during the rainy season, as shown in Appendix Tables 37, 38, 39 and 40. The levels of phosphorus in the forage during the dry and rainy seasons were below the minimum recommended by Cunia et al. (34) for beef cattle in Florida. The levels of the other minerals were always above the minima recommended for Florida. However, it is important to notice that the calcium-phosphorus ratio was almost always above $4: 1$ which could also adversely affect animal performance, particularly with low phosphorus concentrations. The phosphorus deficiency in the forage seemed to be associated with deficiency of this element in the soil (Appendix Table 15), and movement of the nutrient in the plant as the dry season progressed. This suggests the necessity to supply additional phosphorus to the animals throughout the year to improve rates of growth and reproduction under similar conditions in the tropics.

The evaluation of the jaraguagrass forage quality in this experiment indicated that this forage plant was unsuitable for an intensive 
grazing program during the dry season, even with fertilization. The agronomic qualities of the plant could be useful to provide roughage if feed supplement were used during the dry season. There is also the possibility of including a legume in the pasture or nitrogen fertilization during the rainy season to improve the pasture quality. However, some other tropical grasses could be adapted to the region and give better results than jaraguagrass, if they were properly managed. 
SUMMARY AND CONCLUSIONS

The effect of nitrogen fertilization during the latter part of the rainy season on the movement of nutrients from a tropical grass, jaraguagrass (Hyparrhenia rufa (Nees) Stapf), during the dry season was studied in a hot savanna in Guanacaste Province, Costa Rica. The nutritive value of the forage harvested during the dry and following rainy season was also evaluated. The experimental design was a split-plot with three replications, three nitrogen treatments $(0,75$ and $150 \mathrm{~kg}$ nitrogen per ha in the form of ammonium nitrate), and eight harvests along the dry season on a three-year-old sward that had not been grazed or fertilized before. The experiment was established on October 13, 1965 after the forage accumulated during the earlier part of the rainy season was cut by machete and the trash removed. An equivalent of $37.5 \mathrm{~kg}$ phosphorus per ha in the form of concentrated superphosphate was applied uniformly to all the plots. The subplots were harvested at $48,62,84,92,105$, 115, 128 and 143 days of growth into the ary season for determination of dry matter production, and nitrogen, phosphorus, potassium, calcium and magnesium concentrations in the forage. The roots in the top $20 \mathrm{~cm}$ of soll were sampled at each harvest to determine dry matter, and nitrogen and phosphorus concentrations. Cellulose concentrations and in vitro cellulose digestion after $36 \mathrm{hr}$ of fermentation were determined on forage samples from the 48-, $92-$ and 143-day growth periods to determine the value of the forage as a roughage, after the in vitro cellulose digestion 
pattern for the grass was established at $6,12,18,24,36,48$ and $74 \mathrm{hr}$, respectively. In addition, the soil profile was characterized and samples were taken for physical and chemical analysis.

The characteristics of the soil fall into the category of the order Vertisol. The physical properties of the soil seemed to be adequate for field crops and pasture productions. The native fertility seemed to be low, especially in nitrogen and phosphorus.

Dry matter production increased with nitrogen fertilization to the middle of the dry season and decreased after the seed production when the plants in the field began to dry and deteriorate. The effect of nitrogen was highly significant but there was no significant difference between the $N_{1}$ and $N_{2}$ treatments and no interaction between nitrogen treatments and days of growth. At the same time the dry matter of the roots followed more or less the same pattern as the shoots, although difficulties in sampling prevented making any definitive conclusions concerning these results.

Forage nitrogen concentrations as well as the total nitrogen contents increased with nitrogen fertilization to $1.44 \%$ and $52.3 \mathrm{~kg}$ per ha, respectively, with the $\mathrm{N}_{2}$ treatment at 48 days of growth. However, there was a highly significant interaction with days of growth which nullified any nitrogen effect after 84 days. The forage nitrogen concentration decreased to $0.3 \%$ and the nitrogen content to $14.6 \mathrm{~kg}$ per ha with the $\mathrm{N}_{2}$ treatment at the end of the experiment. The nitrogen concentrations and the total nitrogen contents of the roots also increased with the $\mathrm{N}_{2}$ treatment and tended to increase as the plant matured. There were significant 


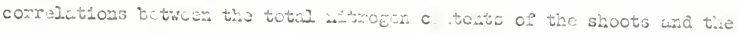
rorts for the nitiogen fertilider treatrents bit no correlation was found for the costrol treatuents.

Nitrogen zacovery by the kunaje mora the azllied fertilizer was less than $45 \%$ for the first harvest date and decreased to less than $20 \%$ at the end of the exporiment, regaraless of the nitrogen treatment.

The concentrations of phosyorus in the shoots decreased from about $0.19 \%$ at the beginning of the expuriment to about $0.05 \%$ at the end and the decrease was acce-ierated by increasing rates of nitrogen fertilization. At the same time whe concenurations athosphorus in the roots tended to increase as the plints wathed. Wivie was a direct relationship between the nitroges and phosphom concentraticns in the shoots at different stages $O P$ maturity ard the correlation was highly signilicant for each nitrogen treatment. The totai phosphorus conteris of the forage decreased from $6.9 \mathrm{~kg}$ per ka at the beginning of the experiment to 2.4 at the exd, with the $\mathrm{M}_{2}$ treatment. Miere was a direct relationship between the total nitroecu and tot 1 phosphomus contents of the forage at difierent stages of zaturity and the comelatic: was hichly sigalicant for each witrogen treatronz.

The celluilose concentrations in the Ponc increased significantiy with nitrogen fertilizstion froi about $30 \%$ to about $30 \%$ at the end of the experiment. There was also a highly signficont interaction with the days of growh. The in vitro coliulose digestion increased with ritrogen fertslizatica fron $44 \%$ to avout $4 g^{\prime}$ at thu pirst harvest cate. Thare was a hichly straficent decrecse in the digcsticn of the forage as the

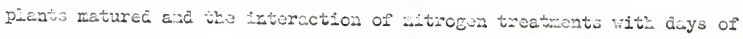
growth was highly significe it. 
The same plots were harvested on August 19, 1966 in the middle of the rainy season after completion of the first part of the experiment. The plots were not refertilized and the purpose of this second part was to evaluate residual effects of the fertilizer applied at the beginning of the experiment, and dry-season harvest dates on plant regrowth. There was no significant residual effect of the applied nitrogen on the dry matter production, nitrogen concentration and total nitrogen content of the forage. Harvest dates had a significant effect on the regrowth. The interaction of the nitrogen treatment with days of growth was significant for dry matter production, nitrogen concentrations and total forage nitrogen content.

The nutritive value of the forage in terms of crude protein was low for both the dry and rainy seasons. The cellulose contents and digestion values seemed to be fairly good for the dry season and this could be compensated by the amount of dry matter produced which could support a high stocking rate if a protein supplement were used. The phosphorus concentrations in the forage were low for both seasons but the potassium, calcium and magnesium concentrations seemed to be adequate for cattle production throughout the year. The forage phosphorus deficiency may have been associated with the deficiency of this element in the soil.

The following conclusions can be drawn from the field experiment to support the hypothesis of translocation from the shoots to the roots of jaraguagrass as being the main mechanism responsible for losses of nitrogen and phosphorus from the herbage during the dry season. 
1. Nitrogen moved out of the herbage regardless of nitrogen fertilization to an equivalent of $150 \mathrm{~kg}$ of the element per ha applied at the end of the rainy season.

2. Volatilization was not likely responsible for all the nitrogen lost because of the large quantities involved and no known mechanisms of nitrogen volatilization from the leaf occurs in green plants, except in very small quantities in some species, according to the literature.

3. A comparison of these results with data obtained by Andrade et al. (2) in the same savanna region in Costa Rica showed that the movement of nitrogen from the grass herbage occurred In soils of different textures and under slightly different moisture regimes.

4. There was a tendency for the dry weights and total nitrogen contents of the roots to increase during the dry season after fertilization with nitrogen at the end of the rainy season. There seemed to be a direct relationship between the decrease of the total nitrogen content of the shoots and the increase of the total nitrogen content of the roots with nitrogen fertilization as the dry season progressed.

5. There was a rapid decrease in the phosphorus content of the herbage during the dry season. There was little possibility that phosphorus could have been volatilized by any known mechanisms in the green plants, so it must have been translocated to the roots during the soil moisture stress. Nitrogen and phosphorus may have been involved in the same process or 
processes because of the close relationship of these two elements in plant metabolism.

6. The nitrogen and phosphorus movements from the herbage were closely related and occurred in the plant while it was still growing, as indicated by the increase in dry matter production. protein metabolism in the plant changed during the ary season regardless of the nitrogen fertilization at the end of the rainy season.

7. The decrease in soil moisture during the dry season seemed to be the main environmental factor determining the change in plant nitrogen metabolism based on field data, observations and information reported in the literature. Changes in night temperatures and photoperiodism may also have had some effect 
APPENDIX 
Table 13.- Profile descriptions of the soil from the experimental area

$\mathrm{cm}$

$0-20$

$20-40$

$40-95$

$95-130$

$20-40$

$40-100$

$0-20$

$100-130$

\section{Pit 1}

Dark reddish brown ( 5 YR 3/2) clay; medium granular structure; slightly firm, friable; intermediate drainage; gradual boundary; $\mathrm{pH}$ in $\mathrm{H}_{2} \mathrm{O}, 6.3 ; \mathrm{pH}$ in $\mathrm{N} \mathrm{KCl}, 5.5$.

Dark yellowish brown ( $10 \mathrm{YR} 4 / 4$ ) clay; medium-coarse granular structure; firm friable; intermediate drainage; clear boundary; small yellow concretions; $\mathrm{pH}$ in $\mathrm{H}_{2} \mathrm{O}, 6.3$; $\mathrm{pH}$ in $\mathrm{N} \mathrm{KCl}$,
5.5.

Very dark gray ( 5 YR 3/I) clay; coarse blocky structure; firm, plastic, sticky; poor drainage; clear boundary; small white and yellow concretions; $\mathrm{pH}$ in $\mathrm{H}_{2} \mathrm{O}, 6.1 ; \mathrm{pH}$ in $\underline{\mathrm{N}} \mathrm{KCl}, 5.4$.

Dark yellowish brown ( $10 \mathrm{YR} 4 / 4$ ) clay; coarse prismatic structure; firm, plastic, sticky; poor drainage; clear boundary; large white and yellow concretions, few small stones; $\mathrm{pH}$ in $\mathrm{H}_{2} \mathrm{O}, 6.5 ; \mathrm{pH}$ in $\mathrm{N} \mathrm{KCl}, 5.4$.

\section{Pit 2}

Dark redish brown ( $5 \mathrm{YR} \mathrm{3/2)} \mathrm{clay;} \mathrm{medium} \mathrm{granular} \mathrm{structure;}$ slightly firm, friable; intermediate drainage; gradual boundary; $\mathrm{pH}$ in $\mathrm{H}_{2} \mathrm{O}, 6.4 ; \mathrm{pH}$ in $\mathrm{N} \mathrm{KCl}, 5.5$.

Dark yellowish brown ( $10 \mathrm{YR} 4 / 4$ ) clay; crumbs structure; slighly firm, friable, intermediate drainage; clear boundary; small yellow concretions; $\mathrm{pH}$ in $\mathrm{H}_{2} \mathrm{O}, 6.6$; $\mathrm{pH}$ in $\mathrm{N} \mathrm{KCl}, 5.4$.

Very dark gray ( 5 YR 3/1) clay; coarse to very coarse blocky structure; firm, plastic, sticky; poor drainage, mottled; small white and yellow concretions, few small stones; $\mathrm{pH}$ in $\mathrm{H}_{2} \mathrm{O}, 6.7 ; \mathrm{pH}$ in $\mathrm{N} \mathrm{KCl}, 5.3$.

Dark yellowish brown ( $10 \mathrm{YR}$ 4/4) clay; medium blocky structure; firm, plastic, sticky; poor drainage; large white and yellow concretions, few small stones; $\mathrm{pH}$ in $\mathrm{H}_{2} \mathrm{O}, 6.7$; $\mathrm{pH}$ in $\mathrm{N} \mathrm{KCl}$, 


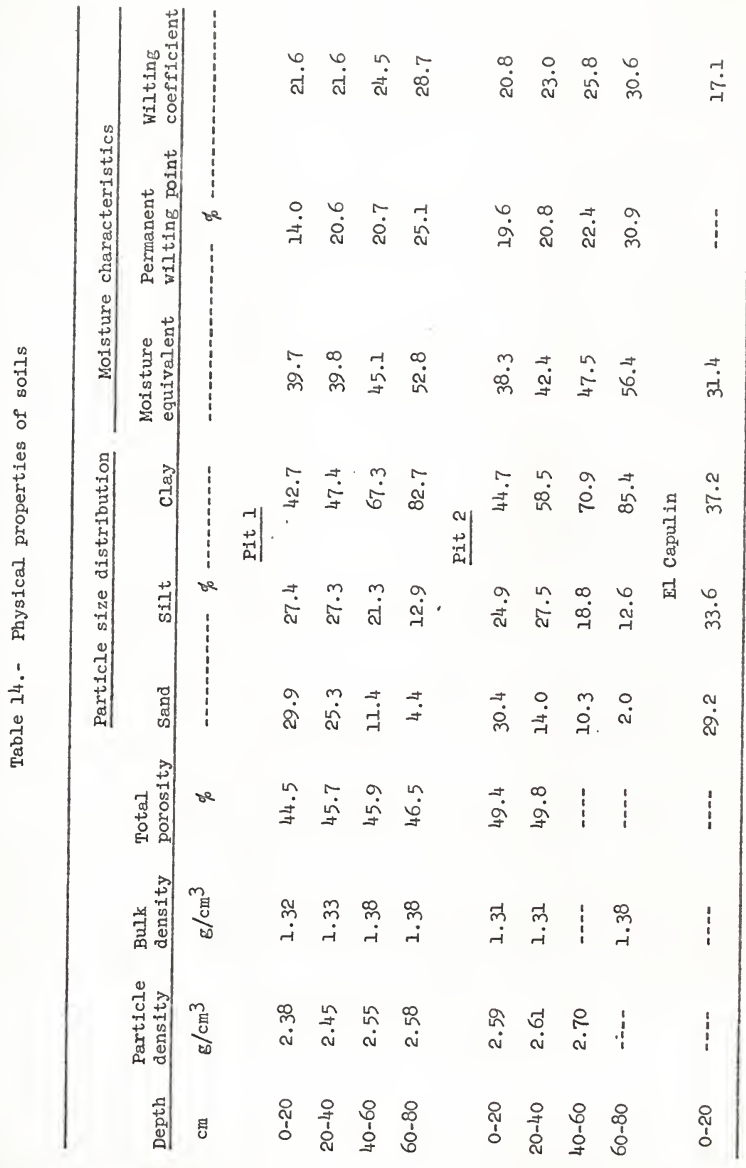




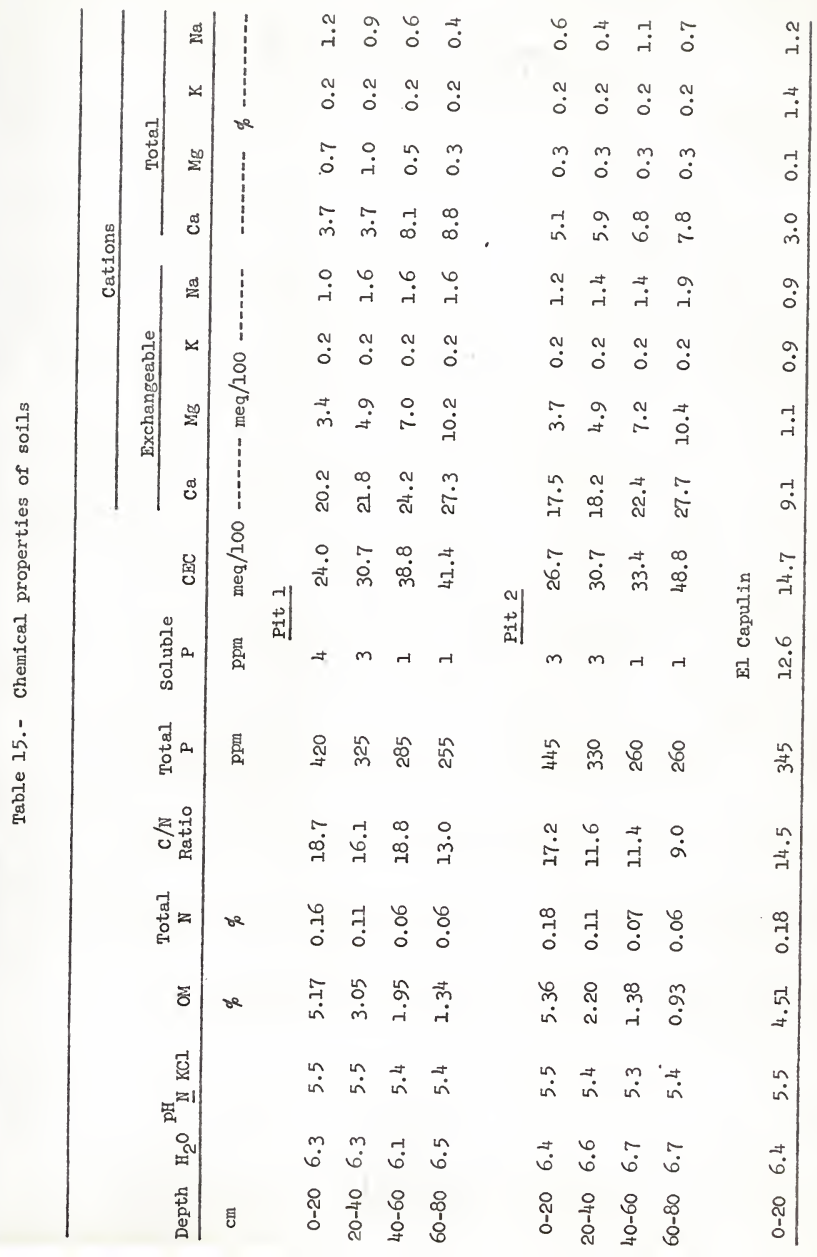


Table 16. - Analysis of variance for yields of oven-dry jaraguagrass forage during the dry season

\begin{tabular}{lccc}
\hline Source of variation & $\begin{array}{c}\text { Degrees } \\
\text { of } \\
\text { freedom }\end{array}$ & Mean squares & F \\
\hline Main plots: & 2 & $64,259,937$ & $68.95^{* *}$ \\
N treatments & 2 & 238,525 & \\
Blocks & 4 & 932,011 & \\
Main plot error & &
\end{tabular}

Sub-plots:

Days of growth

Days $\mathrm{X} N$ treatments

Sub-plot error
7

14

42
$6,349,648$

$9.99 * *$

629,347

635,367

** Significant at the I\% level. 


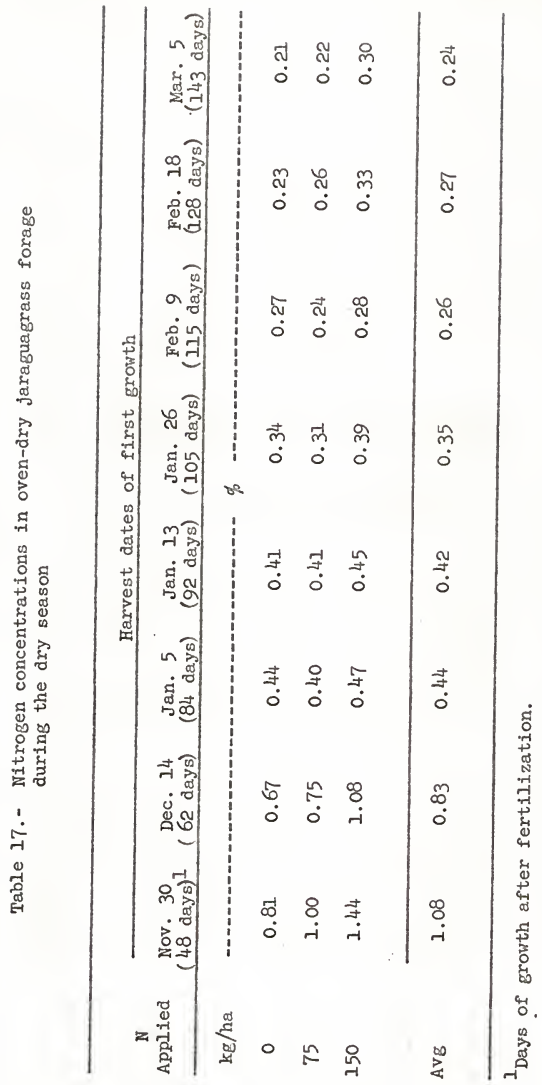




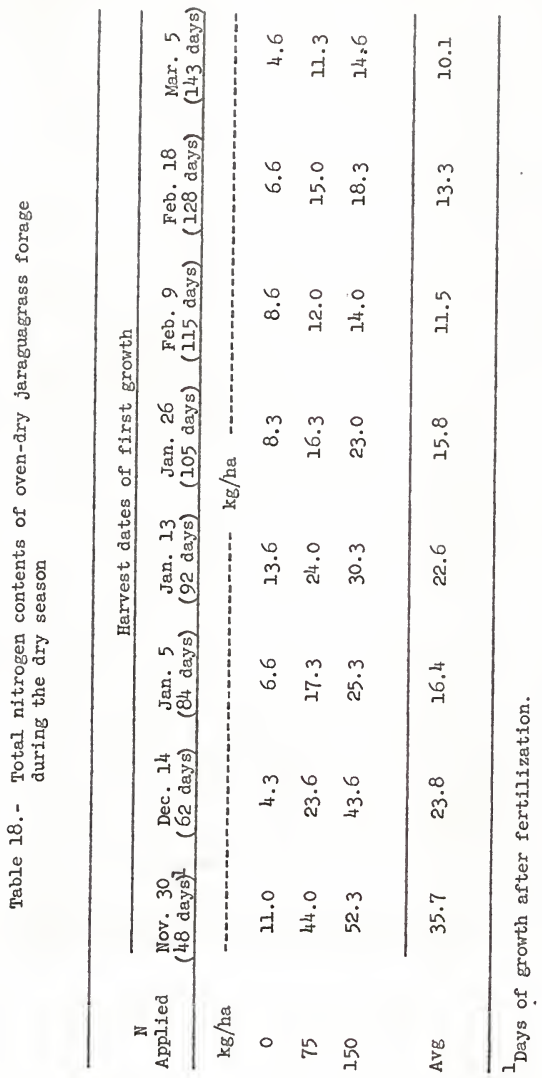


Table 19.- Analysis of variance for nitrogen concentrations in oven-dry jaraguagrass forage during the dry season

\begin{tabular}{lll}
\hline Source of variation & $\begin{array}{c}\text { Degrees } \\
\text { of } \\
\text { freedom }\end{array}$ & Mean squares
\end{tabular}

Main plots:

$\begin{array}{llll}N \text { treatments } & 2 & 0.2004 & 111.33^{* *} \\ \text { Blocks } & 2 & 0.0032 & \\ \text { Main plot error } & 4 & 0.0018\end{array}$

Sub-plots :

Days of growth

7

0.8447

$703.91 * *$

Days $\mathrm{X}$ N treatments

14

0.0402

$33.50 * *$

Sub-plot error

42

0.0012

** Significant at the $1 \%$ level. 
Table 20.- Analysis of variance for total nitrogen contents of oven-dry jaraguagrass forage during the dry season

\begin{tabular}{|c|c|c|c|}
\hline Source of variation & $\begin{array}{l}\text { Degrees } \\
\text { of } \\
\text { freedom }\end{array}$ & Mean squares & $F$ \\
\hline \multicolumn{4}{|l|}{ Main plots: } \\
\hline $\mathrm{N}$ treatments & 2 & 2.385 & $33.12 * *$ \\
\hline Blocks & 2 & 38 & \\
\hline Main plot error & 4 & 72 & \\
\hline \multicolumn{4}{|l|}{ Sub-plots: } \\
\hline Days of growth & 7 & 641 & $18.31 * *$ \\
\hline Days X N treatments & 14 & 150 & $4.28 * *$ \\
\hline Sub-plot error & 42 & 35 & \\
\hline
\end{tabular}

** Significant at the $1 \%$ level. 


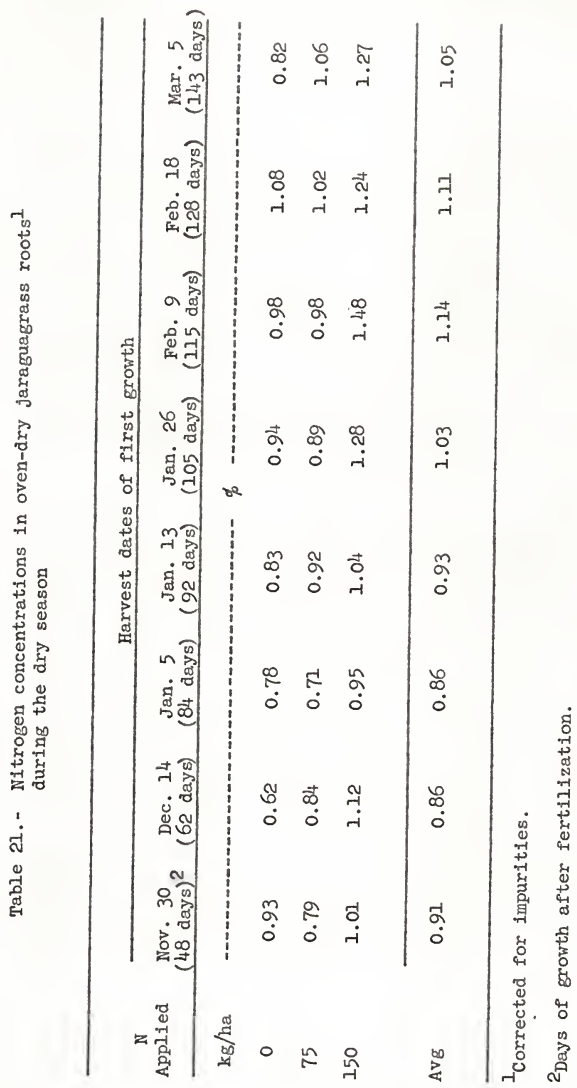




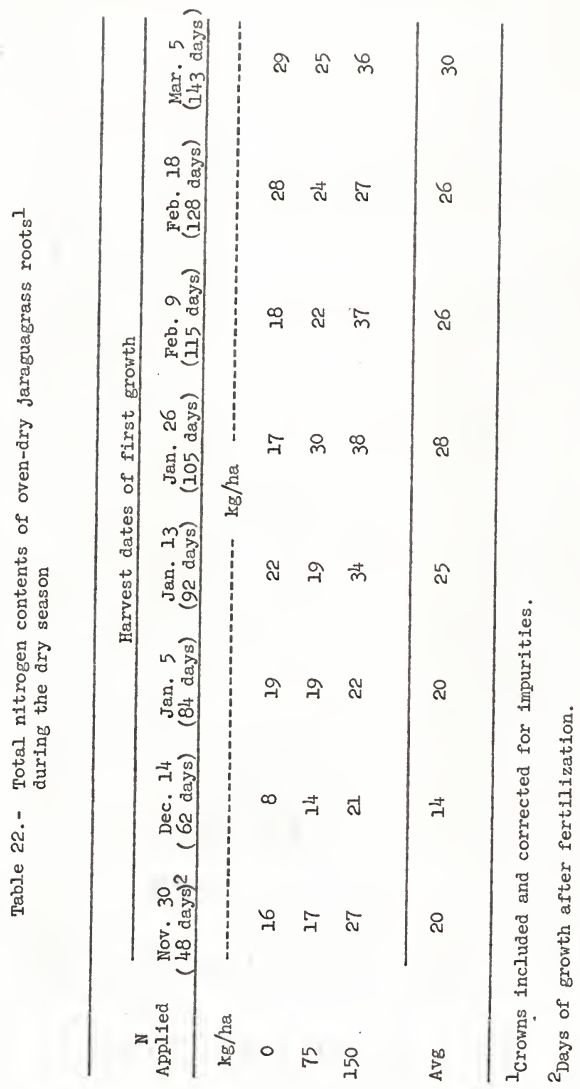




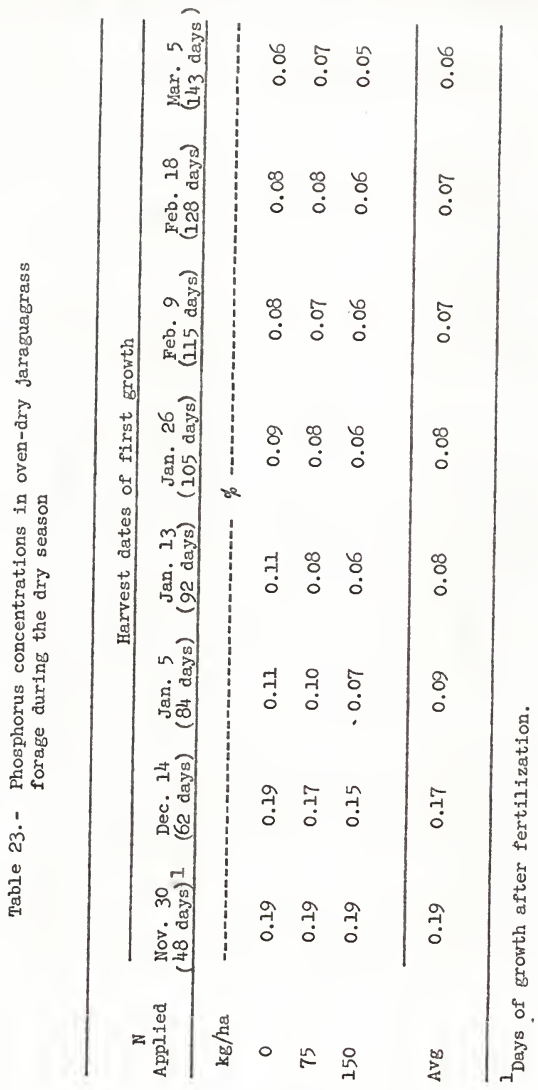


Table 24.- Analysis of variance for phosphorus concentrations in oven-dry jaraguagrass forage during the dry season

\begin{tabular}{|c|c|c|c|}
\hline Source of variation & $\begin{array}{l}\text { Degrees } \\
\text { of } \\
\text { freedom }\end{array}$ & Mean squares & $F$ \\
\hline \multicolumn{4}{|l|}{ Main plots: } \\
\hline $\mathbb{N}$ treatments & 2 & 0.00435 & $17.4 *$ \\
\hline Blocks & 2 & 0.00020 & \\
\hline Main plot error & 4 & 0.00025 & \\
\hline \multicolumn{4}{|l|}{ Sub-plots: } \\
\hline Days of growth & 7 & 0.02078 & $109 \cdot 3^{* *}$ \\
\hline Days X N treatments & 14 & 0.00093 & $4.9 * *$ \\
\hline Sub-plot error & 42 & 0.00019 & \\
\hline
\end{tabular}

Significant at the $5 \%$ level. ** Significant at the $1 \%$ level. 


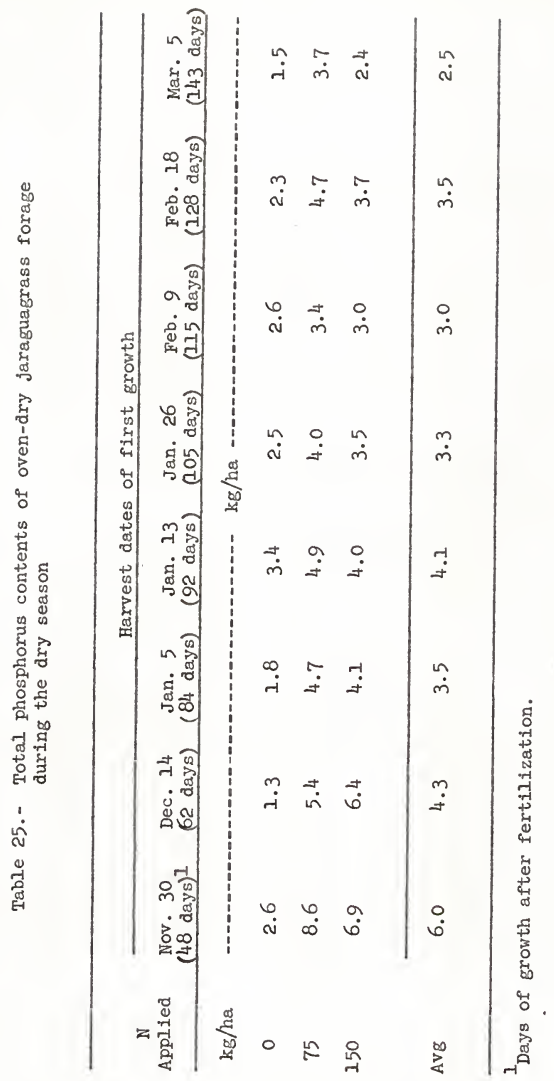


Table 26.- Analysis of variance for total phosphorus contents of oven-dry jaraguagrass forage during the dry season

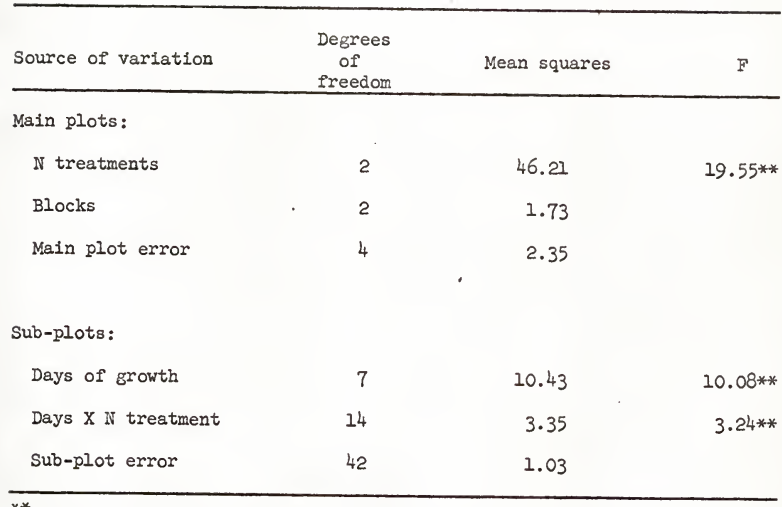

Significant at the $1 \%$ level. 


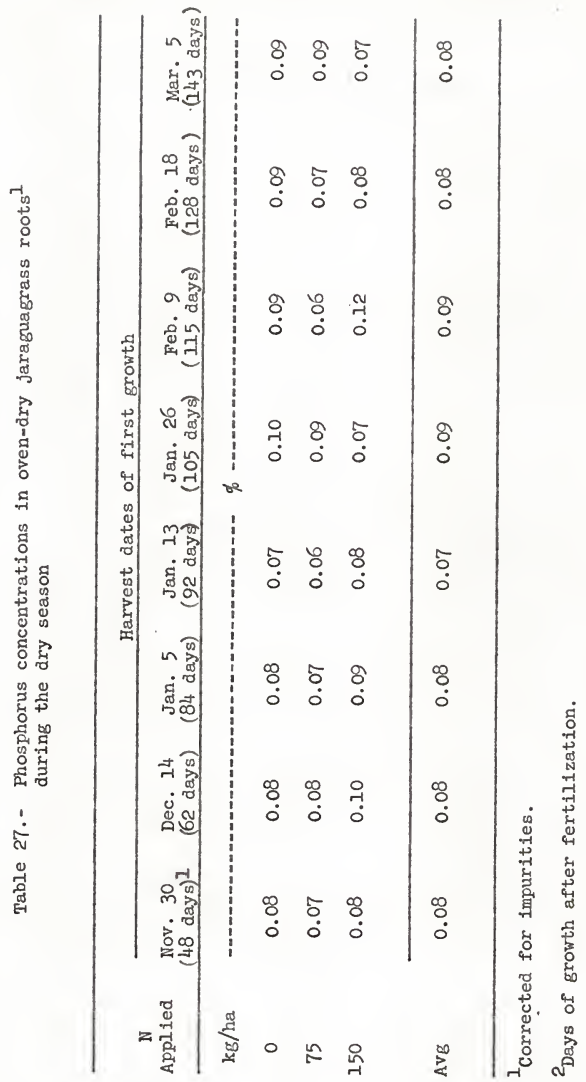




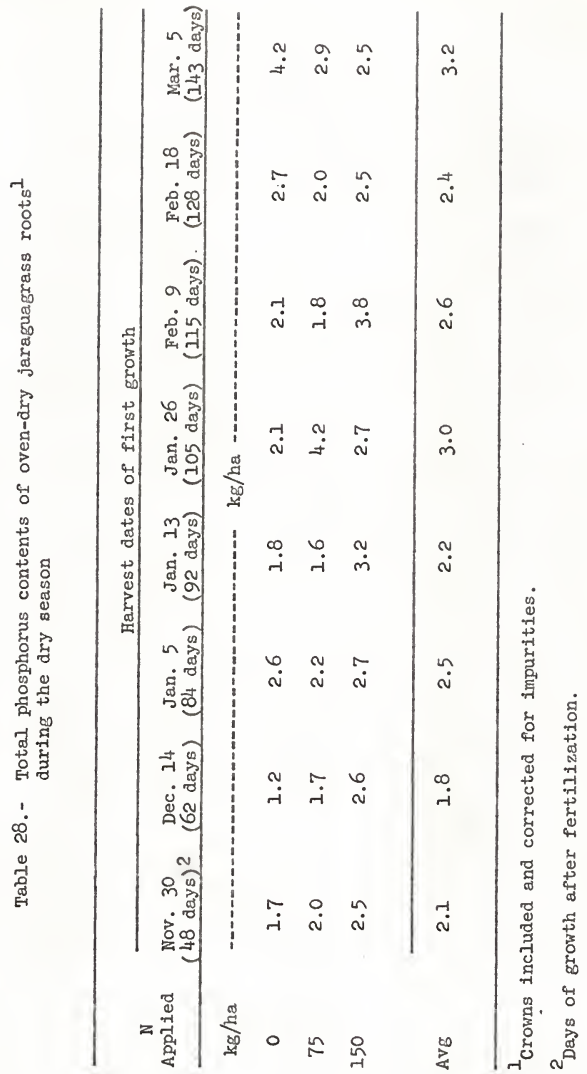


Table 29.- Analysis of variance for yields of oven-dry jaraguagrass forage during the rainy season

\begin{tabular}{lccc}
\hline Source of variation & $\begin{array}{c}\text { Degrees } \\
\text { of } \\
\text { freedom }\end{array}$ & Mean squares & F \\
\hline Main plots: & 2 & $1,648,717$ & 0.20 \\
N treatments & 2 & 817,081 & \\
Blocks & 4 & $7,945,482$ & \\
Main plot error & $74.99 *$ \\
Sub-plots: & 74 & $3,219,417$ \\
Days of growth & 42 & $3,811,405$ \\
Days X N treatments & & $1,074,933$ \\
Sub-plot error & $74 *$ &
\end{tabular}

*

Significant at the 5\% level. **

Significant at the $1 \%$ level. 
Table 30.- Analysis of variance for aitrogen concentrations in oven-dry jaraguagrass forage during the rainy season

\begin{tabular}{|c|c|c|c|}
\hline Source of variation & $\begin{array}{l}\text { Degrees } \\
\text { of } \\
\text { freedom }\end{array}$ & Mean squares & $F$ \\
\hline \multicolumn{4}{|l|}{ Main plots: } \\
\hline N treatments & 2 & 0.00225 & 0.45 \\
\hline Blocks & 2 & 0.00785 & \\
\hline Main plot error & 4 & 0.00503 & \\
\hline Sub-plots: & & & \\
\hline Days of growth & 7 & 0.00437 & $2.93^{*}$ \\
\hline Days $\mathrm{X} N$ treatments & 14 & 0.00369 & $2.47 *$ \\
\hline Sub-plots error & 42 & 0.00149 & \\
\hline
\end{tabular}

*Significant at the $5 \%$ level. 
Table 31.- Analysis of variance for total nitrogen contents of oven-dry jaraguagrass forage during the rainy season

\begin{tabular}{lll}
\hline Source of variation & $\begin{array}{c}\text { Degrees } \\
\text { of } \\
\text { freedom }\end{array}$ & Mean squares
\end{tabular}

Main plots:

$\begin{array}{lccc}\text { N treatments } & 2 & 4.5 & 0.05 \\ \text { Blocks } & 2 & 17.0 & \\ \text { Main plot error } & 4 & 93.5\end{array}$

Sub-plots :

$\begin{array}{lccc}\text { Days of growth } & 7 & 46.2 & 2.70 * \\ \text { Days X N treatments } & 14 & 52.2 & 3.05 * * \\ \text { Sub-plot error } & 42 & 17.1 & \end{array}$

* Significant at the $5 \%$ level. ** Signiflcant at the $1 \%$ level. 
Table 32.- Analysis of variance for cellulose concentrations in oven-dry jaraguagrass forage during the dry season

\begin{tabular}{lccc} 
Source of variation & $\begin{array}{c}\text { Degrees } \\
\text { of } \\
\text { freedom }\end{array}$ & Mean squares & F \\
\hline Replications & 2 & 71.51 & $368.50 * *$ \\
N treatments, N & 2 & 324.28 & $126.14 * *$ \\
Days of growth, D & 2 & 111.01 & $37.21 * *$ \\
Interaction, ND & 4 & 32.75 & 0.88 \\
Error & 16 & &
\end{tabular}

$* *$

Significant at the $1 \%$ level. 
Table 33.- Analysis of variance for in vitro cellulose digestion of oven-dry jaraguagrass forage during the dry season

\begin{tabular}{lccc} 
Sources of variation & $\begin{array}{c}\text { Degrees } \\
\text { of } \\
\text { freedom }\end{array}$ & Mean squares & F \\
\hline Replication & 2 & 14.94 & $30.27 * *$ \\
N treatments, N & 2 & 198.03 & $146.81 * *$ \\
Days of growth, D & 2 & 960.14 & $4.32 * *$ \\
Interaction, ND & 4 & 28.25 & 6.54 \\
Error & 16 & & \\
\hline
\end{tabular}

** Significant at the $1 \%$ level. 


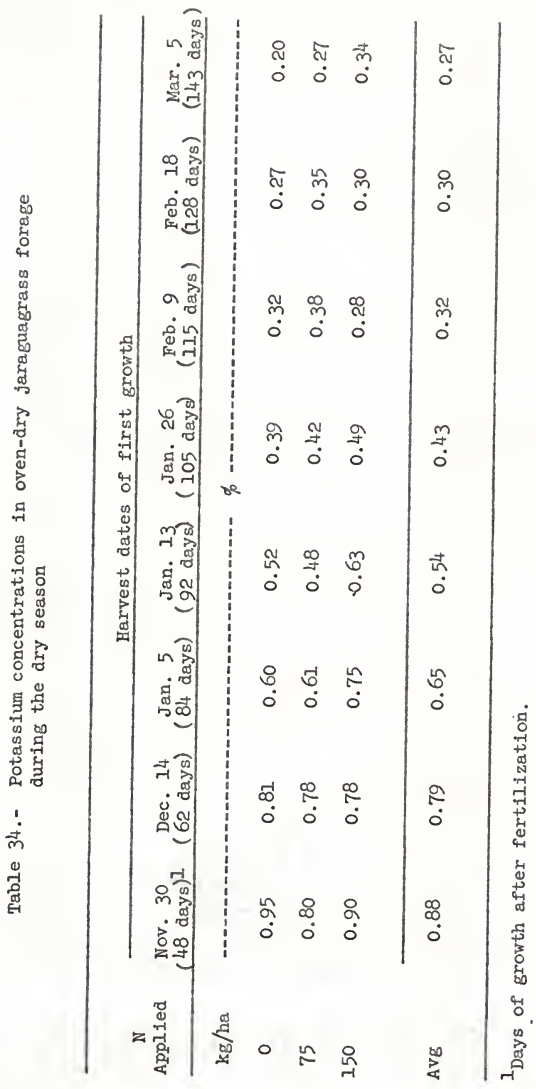




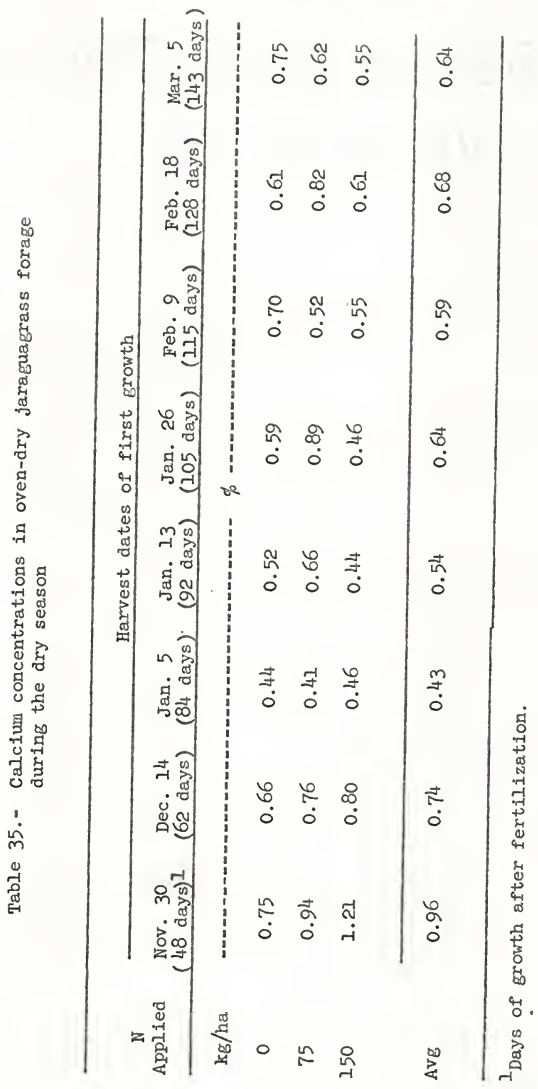




\section{क्ष \\ 0 \\ c్ర \\ म्न \\ है}

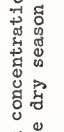

园尔

of 60

व

营

'̊

年

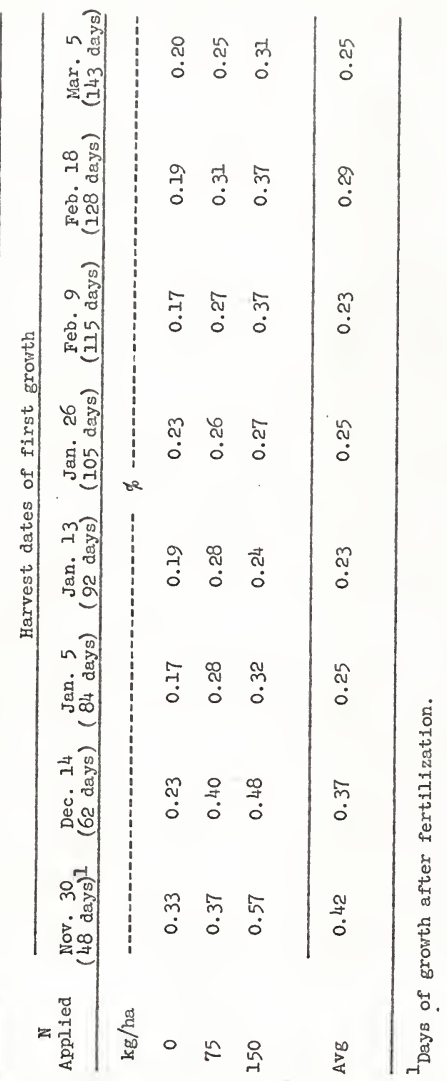




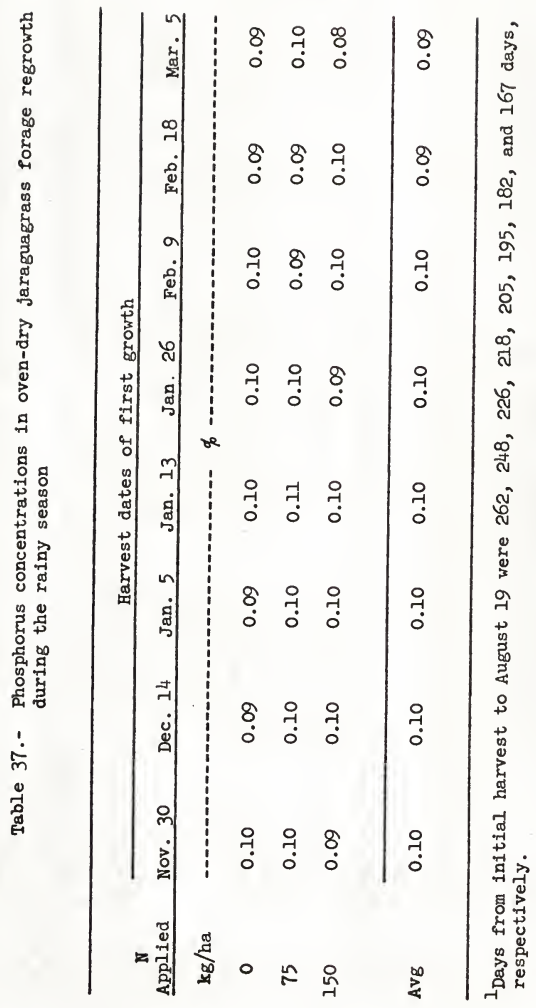




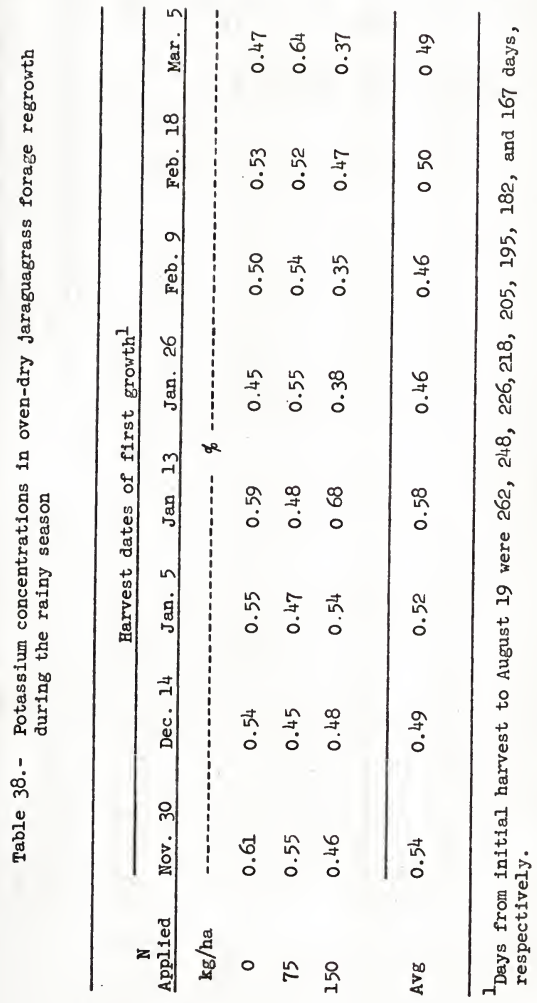




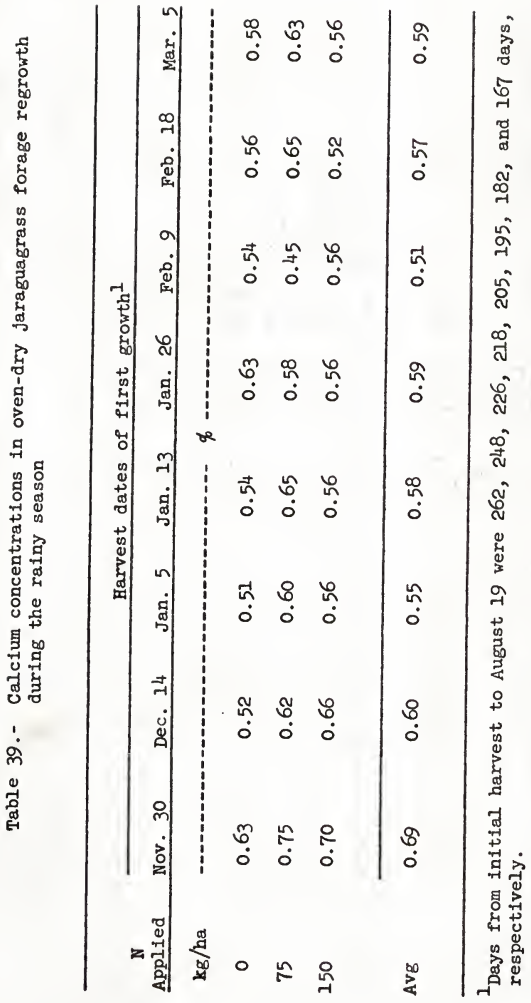




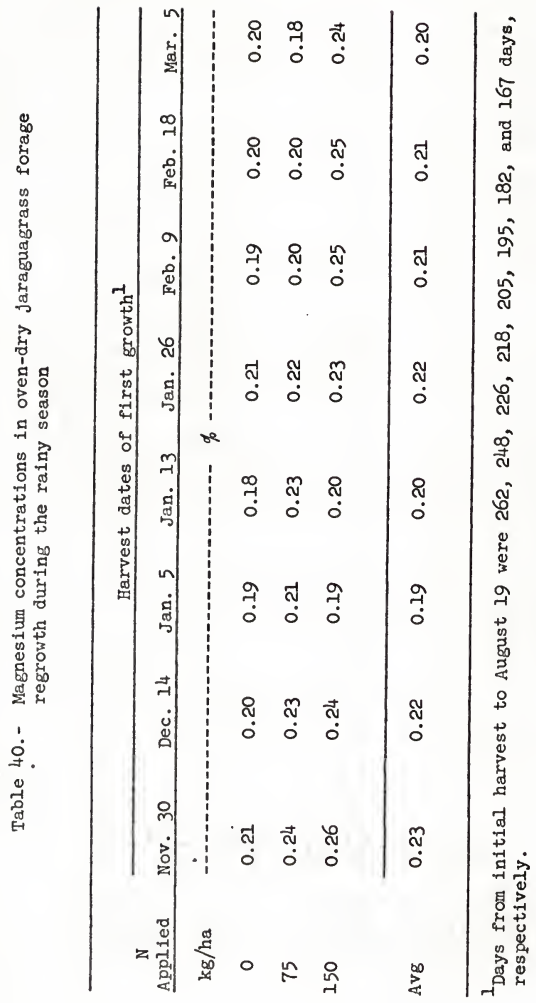




\section{LIST OF REFERENCES}

1. Allison, F. E., K. S. Love, I. A. Pinck, and V. I. Gaddy. 1948. Gaseous losses of nitrogen from green plants. I studies with Chlorella and Lemma. Plant Physiol. 23: 496-504.

2. Andrade, J. I., G. E. Rey, M. T. Ramirez, Ch. A. Carrillo, and W. G. Blue. 1964. Fertilizer responses and dry season changes in forage grasses in the Pacific region of costa Rica. Trop. Agriculture, Trin., 41: 31-39.

3. Arroyo, R. D., and H. Teunissen. 1964. Comparative study of meat production from five tropical grasses. Téc. Péc., Méx. 15-19.

4. Awan, A. B. 1966. Fertilization of old jaragua pastures in Honduras. Int. Grassld Congr. 9th (Sao Paulo, Brazil). I: 675-676.

5. Barnett, N. M., and A. W. Naylor. 1966. Amino acid and protein metabolism in bermudagrass during water stress. Plant Physiol. 41: $1222-1230$.

6. Bedrak, E., A. C. Warnick, J. E. Hentges, Jr., and T. J. Cunha. 1964. Effects of protein intake on gains, reproduction, and blood constituent of beef heifers. Florida Agr. Exp. Sta. Bull. 678. $30 \mathrm{p}$.

7. Birch, H. F. 1958. The effect of soil drying on humus decomposition and nitrogen availability. Plant and Soil. 10: 9-3l.

8. Blake, G. R. 1965. Bulk density. In C. A. Black (ed.) Methods of Soil Analysis. Part I. Agronomy $9: \frac{1}{374-390 .}$

9. Blue, W. G., Andrade, I. J., E. G. Rey, M. T. Ramirez, L. L. Larson, and $W . E$. Schaefer. 1963. Investigations of the potential for pasture development in the AtIantic zone of Costa Rica. Soil and Crop Sci. Soc. Fla. 23: 209-22l.

10. Boerendonk, M. J. 1959. Het landgebruik op Cuba (Land use in Cuba). Tijdschr. econ. soc. Geogr. 50: 151-157.

11. Botha, A. D. P. 1963. Die invloed van gras (Eragrostis curvula) op die amonium en nitraatstikstof' in ' $n$ swart kleigrond (The influence of grass (Eragrostis curvula) on the ammonium and nitrate content of a black clay soil). South Afric. J. Agric. Sci. 6: 3-17. 
12. Bouyoucos, G. J. 1962. Hydrometer method improved for making particle size analyses of soils. Agron. J. 54: 464-465.

13. Braun, 0. 1960. Cultivo de pastos en el Alto Beni (Bolivia). Ministerio de Agricultura, La Paz, Bolivia. Bol. No. $14.13 \mathrm{p}$.

14. Bray, H. L., and L. T. Kurtz. 1945. Determination of tatal organic and available forms of phosphorus in soils. Soil Sci. 59: 39-45.

15. Brendon, R. M., and C. R. Horrell. 1961. The chemical composition and nutritive value of some common grasses in Uganda. I General pattern of behavior of grasses. Trop. Agriculture, Trin., 38: 297-304.

16.

and nutritivive 1962. The chemical composition of chemical composit of some common grasses in Uganda. II The comparison the year, with special reference to value of grasses throughout Trop. Agriculture, Trin., 39: 13-17.

17. , K. W. Harker, and B. Marshall. 1963. The nutritive value of grasses grown in Uganda when fed to zebu cattle. I The relation between the percentage of crude protein and another nutrients. J. Agric. Sci. 61: 101-104.

18. Briggs, L. J., and J. M. McLane. 1907. The moisture equivalent of soils. USDA Bur. Solls. Bull. 45, $23 \mathrm{p}$.

19.

H. L. Shantz. 1912. The wilting coefficient for different plants and its indirect determination. USDA Bur. Plant Industries. Bull. $230.77 \mathrm{p}$.

20. Brockington, N. R. 196la. Studies of the growth of a Hyparrhenia dominant grassland in Norther Rhodesia. J. Brit. Grassld Soc. 16: $54-64$.

21. - 1961b. The growth, yield, and protein content of twelve cultivated grasses in Northern Rhodesia. Emp. J. Exp. Agric. 29: 197-211.

22. Butterworth, M. H. 1964. The digestible energy content of some tropical forages. J. Agric. Sc1. 63: 319-321.

23. Carneiro, G. C., J. M. P. Nemoria, V. A. Garwood, and J. R. Torres. 1966. Weight gains of Guzerat calves supplementary fed during the second half of the dry season and pastured on jaraguagrass during the rainy season. Int. Grassld Congr. 9th (São Paulo, Brazil) II:
1655-1660. 
24. Caro-Costas, R., J. Vicente-Chandler, and J. Figarella. 1965. Productivity of intensively managed pastures of five grasses on steep slopes on the humid mountains of Puerto Rico. J. Agriculture, Univeristy of Puerto Rico, 49: 99-111.

25. Carrera, C. 1966. Aprovechaniento y utilizatión de algunos zacates tropicales. El Campo, México. No. 888: 44-50.

26. , and F. M. Ferrer. 1963. Producción de carne de ganado zebu con seis especies de zacates tropicales. Agricultura Técnica, Mexico, 2: 81-86.

27. Cartmill, W. J. 1944. The effects of season, stage of growth, and soil type on the chemical composition of grasses in the Queensland "Wet Belt." The Queensland J. Agric. Sci. 1, (No. 2): 1-31.

28. Carver, H. L., and W. K. Robertson. 1956. A study of some laboratory methods for determining calcium and magnesium. Soil and Crop. Sci. Soc. Fla. 16: 258-271.

29. Chapman, H. D. 1965. Cation-exchange capacity. In C. A. Black (ed.) Methods of Soll Analysis. Part II. Agronomy 9: 891-901.

30. Chen, D., B. Kessler, and S. P. Monselise. 1964. Studies of water regime and nitrogen metabolism of citrus seedlings grown under water stress. Plant Physiol. 39: 319-386.

31. Coaldrake, J. E. 1962. The nitrogen of natural plant communities. In A review of nitrogen in the tropics with particular reference to pastures. A symposium, Commonwealth Bur. Pastures and Field Crops, Hurley, England. Bull. 46: 35-42.

32. Costa Rica. 1958. Estudio semidetallado de suelos de la región comprendida entre los rios Barranca y Lagarto. Ministerio de Agricultura e Industrias. Bol. Téc. No. $24.70 \mathrm{p}$.

33. Crampton, E. W., and C. A. Maynard. 1938. The relation of cellulose and lignin content to the nutritive value of animal feeds. J. Nutr. 15: $383-395$.

34. Cunha, T. J., R. I. Shirley, H. I. Chapman, Jr., C. B. Ammerman, G. K. Davis, W. G. Kirk, and J. F. Hentges, Jr. 1964. Minerals for beef cattle in Florida. Florida Agr. Exp. Sta. Bull. $683.60 \mathrm{p}$.

35. Da Silva, D. J., J. H. Conrad, and J. Campos. 1966. Da digestibilidade "in vitro" de algunas forrageiras tropicais. Int. Grassld Congr. 9 th (säo Paulo, Brazil). I: 895-897. 
36. Davies, W., and C. L. Skidmore. 1966. Reflections and the future. In W. Davies and C. L. Skidmore (ed.) Tropical Pastures. Faber and Faber Limited, London, England. 186-198.

37. Diehl, H. 1963. Calcein, calmagite, and 0,0'-dihydroxyazobenzene titrimetric, colorimetric and fluoremetric reagent for calcium and magneslum. The G. Frederick Smith Chemical Co., Columbus, Ohio. $124 \mathrm{p}$.

38. Dilz, K., and J. W. Woldendorp. 1960. Distribution and nitrogen balance of $15 \mathrm{~N}$-labelled nitrate applied on grass sods. Int. Grassld Congr. 8th (London, England). 150-152.

39. Dudal, R. 1963. Dark clay soils of tropical and subtropical regions, Soil Sci. 95: 264-270.

40. Edwards, D. C., and A. V. Bogdan. 1951. Important grassland plants of Kenya. Sir Isaac Pitman and Sons, Ltd., Nairobi. 124 p.

41. Espinal, I. S. 1964. Plant formations in the Antioquia Department. Rev. Fac, nac. Agron., Medellin, Colombia, 24: 1-83.

42. Fiske, C. H., and Y. Subbarow. 1925. The colorimetric determination of phosphorus. J. Biol. Chem. 66: 375-400.

43. French, M. H. 1941. The nutritive value of some Tanganyika grasses. Emp. J. Exp. Agric. 9: 23-28.

44. L. M. Chaparro. 1960. Contribución al estudio de la composición química de los pastos en Venezuela durante la estación seca. Agronomia Tropical 10: 57-69.

45. J. Glover, and D. W. Duthie. 1956. The apparent digestibility of crude protein by the ruminant. II The general equation and some implications. J. Agric. Sc1. 48: 379-383.

46. Fontana, H. 1961. Las sabanas de Venezuela. Ingeniería Agronómica, Venezuela, 6: 7-11.

47. Gates, C. T. 1957. The response of the young tomato plant to a brief period of water shortage. Aust. J. Biol. Sci. 10: 125-146.

48. Glover, J., D. W. Duthie, and M. H. French. 1956. The apparent digestibility of crude protein by the ruminant. I A synthesis of the results of digestibility trials with herbage and mixed feeds. J. Agric. Sci. 48: 373-377.

49. Greenland, D. J. 1958. Nitrate fluctuations in tropical soils. J. Agric. Sci. 50: 82-92. 
50. Guilbert, H. R., P. Gerlaugh, and I. L. Madsen. 1950. Recommended nutrient allowances for domestic animals. IV Recommended nutrient allowances for beef cattle. National Research Council, Washington, D. C. $30 \mathrm{p}$.

51. Gwynne, M. S. 1966. Plant physiology and the future in tropical pastures. In W. Davis and C. I. Skidmore (ed.) Tropical Pastures. Faber and Faber Limited, London, England. 59-74.

52. Hagenzieker, F. 1957. Soil-nitrogen studies at Urambo, Tanganyika Territory, East Africa. Plant and Soll 9: 97-113.

53. Hardy, F. 1946. Seasonal fluctuations of soil moisture and nitrate in a humid tropical climate (Trinidad, B.W.I.) Trop. Agriculture,
Trin., 23: 40-49.

54. Hegarty, M. P. 1962. Nitrogen uptake and nitrogen transformations in plants. In A review of nitrogen in the tropics with particular reference to pastures. A symposium, Commonwealth Bur. Pastures and Field Crops, Eurley, England. Bull. 46: 83-97.

55. Henzell, E. F. 1962. The use of nitrogen fertilizers on pastures in the sub-tropics and tropics. In A review of nitrogen in the tropics with particular reference to pastures. A symposium, Commonwealth Bur. Pastures and Field Crops, Hurley, England. Burl. 46: 161-172.

56. Hogaboom, H. G. 1952. Establishment and maintenance of pastures in the tropics. Int. Grassld Congr. 6th (Pennsylvania, U. S. A.)
1479-1482.

57. Holt, E. C., and F. I. Fisher. 1960. Root development of Coastal' Bermudagrass with nitrogen fertilization. Agron. J. 52: 593-596.

58. Holter, J. A., and J. T. Reid. 1959. Relationship between the concentrations of crude protein and apparently digestible protein in forages. J. Animal. Sci. 18: 1339-1349.

59. Howard, D. A., and M. I. Burdin. 1962. Variation in the mineral and crude-protein content of pastures at Muguga in the Kenya highlands. J. Agric. Sci. 59: 251-256.

60. Jackson, M. I. 1962. Soll chemical analysis. Prentice-Hall, Inc. N. J. 498 p.

61. Jardim, W. R. 1953. Contribuiçao para o estudo da composiçao e digestibilidade do capim jaragua (Hyparrhenia rufa (Nees) Stapf). Ann. Esc. Agric. Queiroz, Brazil, 10: 277-284. 
62. Jardim, W. R., A. M. Peixoto, C. L. Morais, and S. Silveira Filho. 1966. Contribuicao ao estudo da composicao quimica de plants forrageiras de pastagens do Brazil Central. Int. Grassld Congr. 9th (são Paulo, Brazil). I: 699-704.

63. Jones, D. I. H. 1963. The mineral content of six grasses from a Hyparrhenia dominant grassland in Northern Rhodesia. Rhod. J. Agric. Res. 1: 35-38.

64. 1964. Mineral content of some cultivated grasses grown in Northern Rhodesia. Rhod. J. Agric. Res. 2: 57-59.

65. Katnelson, H., J. W. Rouatt, and T. M. B. Payne. 1955." The liberation of amino acids and reducing compounds by plant roots. Plant and soil. $7: 35-48$.

66. Kemble, A. R., and H. T. Macpherson. 1954. Liberation of amino acids in perennial, rye grass during wilting. Blochem. J. 58: 46-50.

67. Kerp, E. D. S., R. M. MacKenzie, and D. H. Romney. 1961. Productivity of pastures in British Honduras. III Jaraguagrass. Trop. Agriculture, Trin., 38: 161-171.

68. Kessler, B. 1961. Nucleic acids factors in drought resistance of higher plants. Recent Advances in Botany. 2: 1153-1159.

69. Lansbury, T. J., R. R. Innes, and G. L. Mabey. 1965. Studies on Ghana grasslands: yield and composition of the Accra Plains. Trop. Agriculture, Trin., 42: 1-18.

70. Levitt, J. 1964. Drought. In Forage plant physlology and soil-range relationship. ASA Special Publication No. 5: 57-66.

71. Marshall, B., and M. I. E. Long. 1967. The digestible energy content of some East African grasses. E. Afr. Agric. for J. 33: 64-66.

72. Martin, A. E. 1962. Nitrogen transformations in soils, excluding denitrification. In A review of nitrogen in the tropics with particular reference to pastures. A symposium, Commonwealth Bur. Pastures and Field Crops, Hurley, England. Bull. 46: 19-34.

73. and G. W. Skyring. 1962. Losses of nitrogen from the soll-plant system. In A review of nitrogen in the tropics with particular reference to pastures. A symposium, Commonwealth Bur. Pastures and Field Crops, Hurley, England. Bull. 46: 72-82.

74. McIlroy, R. J. 1964. An introduction to tropical grassland husbandry. Oxford University Press, London, England. 128 p.

75. McKee, H. S. 1962. N1trogen metabolism in plants. Clarendon Press, Oxford, England. 728 p. 
76. Meiklejohn, J. 1962. Microbiology of the nitrozen cycle in some Ghana soils. Emp. J. Exp. Agric. 30: 115-126.

77. Milford, R., and D. J. Minson. 1965. The relation between the crude protein content and the digestible crude protein content of tropical pasture plants. J: Brit. Grassld Soc. 20: 177-179.

78. 1966. The feeding value of tropical pastures. In W. Davies and C. L. Skidmore (ed.) Tropical Pastures. Faber and Faber Limited, London, England. 106-114.

79. Niller, T. B., and A. B. Rains. 1963. The nutritive value and agronomic aspects of some fodders in Northern Nigeria. I Fresh herbage. J. Brit. Grassld Soc. 18: 158-167.

80. value and agronomic aspects of some fodders in Northern Nigeria. II Silages. J. Brit. Grassl Soc. 18: 223-229.

81. Moir, R. J. 196l. A note on the relationship between the digestible dry matter and the digestible energy content of ruminant diets. Austral. J. Exp. Agric. Ani. Husb. 1: 24-26.

82. Muro, J. C., and T. 0. Agreda. 1959. Pasto yaragua (Hyparrhenia rufa). Experimentos Agropecuarios, Lima, Perú. Bol. trim. 8: $15-22$.

83. Naga, M. M. A., and K. el-Shazly. 1963. The use of the in vitro fermentation technique to estimate the digestible energy content of some Egyptian forages. I The in vitro digestion of cellulose as a criterion of energy content. J. Agric. Sci. 61: 73-79.

84. Noland, P. R., E. Broce, and I. Vergara. 1959. Uso de fertilizantes en potreros de zacate Jaragua (Hyparrhenla rufa (Nees) Stapf) en Panamá. Turrialba, Costa Rica, 9: 29-35.

85. Nye, P. H., and D. J. Greenland. 1960. The soil under shifting cultivation. Comonwealth Agric. Bur. Tech. Commun. No. 51. 156 p.

86. Oppenheimer, H. R. 1960. Adaptation to drought: xerophytism. Plant-water relationships in arid and semi-arid conditions. Reviews of Research. UNESC0, Paris. 105-138.

87. Oyenuga, V. A. 1957. The composition and agricultural value of some grass species in Nigeria. Emp. J. Exp. Agric. 25: 237-255.

88. Pastore, M., and G. C. Thompson. 1950. Manual del tambero paraguayo. Servicio Técnico Interamericano de Cooperación Agricola, Ministerio de Economía, Asunción, Paraguay. 123 p. 
89. Pearsall, W. H., and M. C. Billimoria. 1937. Losses of nitrogen from green plants. Biochem. J. 31: 1743-1750.

190. Pedreira, J. V. S., J. C. Werner, G. I. da Rocha, and B. Cintra, 1966. Estudos preliminares de introducao de plantas forrageiras no sul do estado de Sa, Paulo. Int. Grassld Congr. 9th (Sao Paulo, Brazil). II: 1537-1542.

91. Peech, M., I. T. Alexander, I. A. Dean, and J. F. Reed. 1947. Methods of soil analysis for soil fertility investigations. USDA Circ. No. $757.25 \mathrm{p}$.

92. Petri, A. H. K., and J. G. Wood. 1938a. Studies on the nitrogen metabolism of plants. I The relation between the content of proteins, amino acids and water in the leaves. Ann. Bot. N. S. 2: 33-60.

93. - 1938b. Studies on the nitrogen metabolism of plants. III On the effect of water content on the relationship between proteins and amino acids. Ann. Bot. N. S. 2: $887-898$.

94. Quicke, G. V., O. G. Bentley, H. W. Scott, and A. I. Moxon. 1959. Cellulose digestion in vitro as a measure of the digestibility of forage cellulose in ruminants. J. Animal Sci. 18: 275-287.

95. Quinn, I. R., G. O. Mott, W. V. A. Bisschoff, and G. I. da Rocha. 1963. Beef production of six tropical grasses. IBEC Res. Inst. Bull. 28. $30 \mathrm{p}$.

96. Ramia, M. 1959. Las sabanas de Apure, Venezuela. Bol. Minist. Agric. y Cria. Caracas, Venezuela. $134 \mathrm{p}$.

97. Rey-Gonzalez, E., and J. Mata-Pacheco. 1966. Cultivo de pastos en Costa Rica, Manual de recomendaciones. Ministerio de Agricultura y Ganaderia, San Jose, Costa Rica. Bol. Tech. No. 51.94 p.

98. Richards, I. A. 1949. Methods of measuring soil moisture tension. Soil Sci. 68: 95-112.

99. Roseveare, G. M. 1948. The grasslands of Latin America. Imp. Bur. of Pastures and Field Crops, Aberystwyth, Great Britain. Bull. 36.

100. Russell, E. W. 1966. Soils and soil fertility. In W. Davies and C. I. Skidmore (ed.) Tropical Pastures. Faber and Faber Limited, London, England. 30-45.

101. Saens-Maroto, A. 1955. Los forrages de Costa Rica. Editorial Universitaria, Seccion de Ciencias Naturales. San Jose Costa Rica. $591 \mathrm{p}$. 
102. Schofield, J. I. 1945. Protein content and yield of grasses in the wet tropics as influenced by seasonel productivity, frequency of cutting and species. The Queensland J. Agric. Sci. 2 (No. 4): $209-243$.

103. 1946. Mineral content and yield of grasses in wet tropics as influenced by seasonal productivity, frequency of cutting and species. The Queensland J. Agric. Sci. 3: 44-79.

104. Shah, C. B., and R. S. Loomis. 1965. Ribonucleic acid and protein metabolism in sugar beet during drought. Physiol. Plantarum 18: $240-254$.

105. Smith, C. A. 1961. The utilization of Hyparrhenia veld for the nutrition of cattle in the dry season. J. Agric. Sci. 57: 305-310.

106. 1962. The utilization of Hyparrhenia veld for the nutrition of cattle in the ary season. J. Agric. Sci. 58: 173-178.

107. 1964. Studies on the Northern Rhodesia Hyparrhenia veld. J. Agric. Sci. 62: 299-306.

108. Snedecor, G. W. 1956. Statistical methods applied to experiments in Agriculture and Biology. 5th Ed. Iowa State Coll. Press., Amer, Iowa. $534 \mathrm{p}$.

109. Soll survey Staff. 1960. Soil classification, a comprehensive system, 7 th approximation. USDA Soil Conservation Service. 265 p.

110. Standley, P. C. 1937. Flora of Costa Rica. Publications of Field Museum of Natural History, Chicago, U. S. A. Part I Botanical Series 18: $16-21$.

111. Stobbs, T. H. 1965. Beef production from Uganda pastures containing Stylosanthes gracilis and Centrocema pubescens. Int. Grassld Congr.

112. , and A. D. H. Joblin. 1966. The use of live weight-gain trials for pasture evaluation in the tropics. J. Brit. Grassld Soc. 21: $181-185$.

113. Stocker, 0. 1960. Physiological and morphological changes in plants due to water deficiency. Plant-water relationships in arid and semi-arid conditions. Reviews of Research, UNESCO, Paris. p. 64-104.

114. Taylor, B. W. 1963. An outline of the vegetation of Nicaragua. J. Ecol. 1: 27-54.

115. Theron, J. J. 1951.. The influence of plants on the mineralization of nitrogen and the maintenance of organic matter in the soil. J. Agric. Sci. 41: 289-296.

116. Todd, J.R. 1956. Investigation into the chemical composition and nutritive value of certain forage plants at the medium altitudes in the tropics. J. Agric. Sci. 47: 29-39. 
117. Troughton, A. 1957. The underground organs of herbage grasses. Commonwealth Bur. Pastures and Field Crops, Hurley, England. Bull. 44. $163 \mathrm{p}$.

118. 1960. Growth correlations between the roots and shoots of grass plants. Int. Grassld Congr. 8th (London, Enfland). $280-283$.

119. Vicente-Chandler, J., and J. Figarella. 1958. Growth characteristics of guinea grass on the semiarid south coast of Puerto Rico, and the effect of nitrogen fertilization on forage yields and protein content. J. Agriculture, University of Puerto Rico, 42: 151-160.

120. S. Silva, and J. Figarella. 1959. Effects of nitrogen fertilization and frequency of cutting on the yield and composition of guinea grass in Puerto Rico. J. Agriculture, University of Puerto Rico, 43: 228-239.

121. , R. Caro-Costas, R. W. Pearson, F. Abruna, J. Figarella, and S. Silva. 1964. The intensive management of tropical forages in Puerto Rico. University of Puerto Rico Agr. Exp. Sta., Rio Piedras, Puerto Rico. Bull. 187. 152 p.

122. Viets, F. G., Jr. 1965. The plant's need for and use of nitrogen. In W. V. Bartholomew and F. E. Clark (ed.) Soll Nitrogen. Agronomy

123. Volk, G. M. 1947. Significance of moisture translocation from soil zones of low moisture tension to zones of hich moisture tension by plant roots. J. Amer. Soc. Agr. 39: 93-106.

124. Vomocil, J. A. 1965. Porosity. In C. A. Black (ed.) Methods of Soil Analysis. Part I. Agronomy 9: 299-314.

125. Walker, T. W. 1956. The nitrogen cyclé in grassland soils. J. Sci. Food Agric. 7: 66-71.

126. Walkley A. 1947. A critical examination of a rapid method for determining organic carbon in soils. Soil Sci. 63: 251-264.

127. Watkins, J. M., and A. V. Chavez. 1948. Providing forage for the dry season in El Salvador. J. Brit. Grassl Soc. 3: 141-151.

128. and height of ' and $M$. Lewy-van Severen. 1951. Effect of frequency on the yield, stand, and protein content of some forages in EI Salvador. Agron. J. 43: 291-296.

129. Weinmann, H. 1940. Storage root reserves in Rhodesgrass. Plant Physiol. 15: $467-484$.

130. 1952. Carbohydrates reserves in grasses. Int. Grassla Congr. 6th (Philadelphia, U. S. A.) p. 655-660. 
131. Weinmann, H. 1955. The chemistry and physiology of grass. In The grasses and pastures of South Africa. Central News Agency. p. 571-600.

132. Whyte, R. O., T. R. G. Moir, and J. P. Cooper. 1959. Grasses in agriculture. FAO Agric. Stud. No. $42.416 \mathrm{p}$.

133. Williams, D. R. 1960. Nutrient uptake by grass roots. Int. Grassld Congr. 8th. (London, England). p. 283-286. 


\section{BIOGRAPHICAL SKETCH}

Luis E. Tergas was born March 23, 1938, at Guaimaro, Cuba. In June 1956, he was graduated from Escuelas Pias High School in Camaguey, Cuba. In April 1959, he entered the Escuela Agricola Panamericana in Honduras. He was graduated with high honors in December 1961, and was awarded the Wilson Popenoe Scholarship to continue studies in Agricultural Sciences. He entered the University of Florida in September 1962 and received the degree of Bachelor of Science in Agriculture in December 1963. He was admitted to the Graduate School of the University of Florida and was granted an assistantship under the Caribbean Research Program. In April 1965 he received the degree of Master of Science in Agriculture. In May 1965 he was granted an assistantship by the Center for Tropical Agriculture to continue his work toward the degree of Doctor of Philosophy.

Luis E. Tergas is married to the former Sonia M. Rosales and is father of one child. He is member of Alpha Zeta, Gamma Sigma Delta, Phi Kappa Phi, Phi Sigma and Sigma Xi Honorary Fraternities, American Society of Agronomy, Soll Science Society of America, Intermational Soil Science Society, American Institute of Biological Science and Soil and Crop Sclence Society of Florida.

Presently he is a candidate for the degree of Doctor of Philosophy. 
This dissertation was prepared under the direction of the chairman of the candidate's supervisory committee and has been approved by 211 members of that comittee. It was submitted to the Dean of the College of Agriculture and to the Graduate Council, and was approved as partial fulfillment of the requirements for the degree of Doctor Philosophy.

August 1968

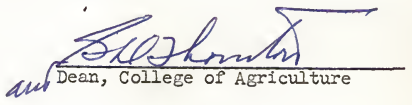

Dean, Graduate School

Supervisory Committee:
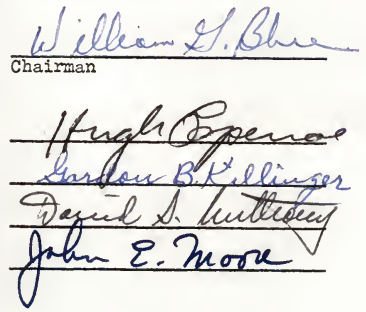